\title{
1984 Annual Report on
}

\section{Alaska's Mineral Resources}

\author{
U.S. GEOLOGICAL SURVEY CIRCULAR 940
}

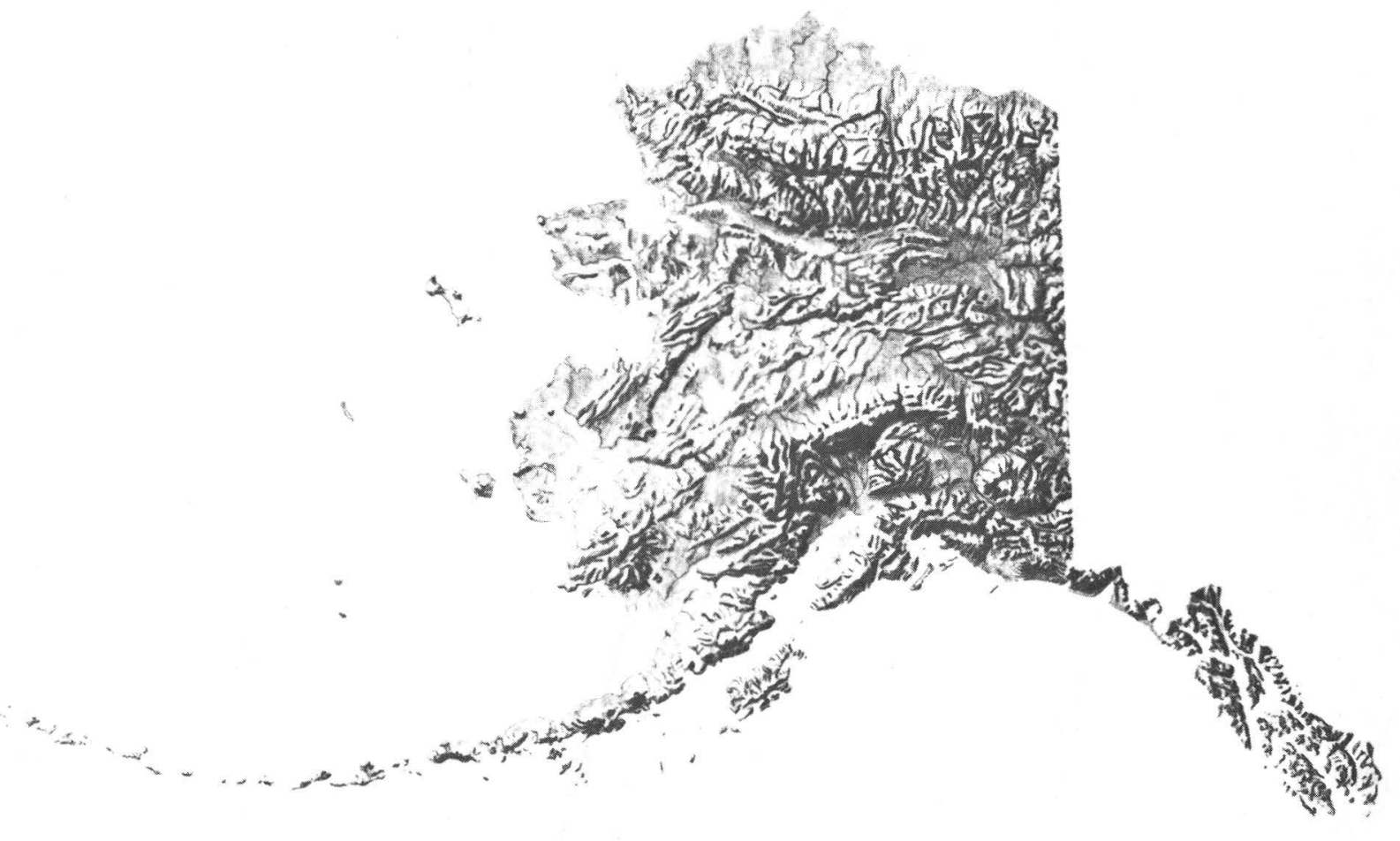

Prepared in cooperation with the

Bureau of Mines, the Bureau of Land

Management, the National Park Service,

the U.S. Fish and Wildlife Service, the

Department of Agriculture-Forest

Service, and the Department of Energy

As mandated by Section 1011 of the

Alaska National Interest Lands

Conservation Act, Public Law 96-487,

of December 2, 1980

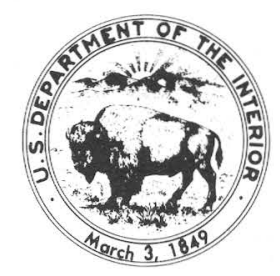


Contributors to this report:

Kenneth Bird, U.S. Geological Survey

James Callahan, Bureau of Land Management

Fred Chiei, Department of Energy

Roger Contor, National Park Service

Norman Day, Forest Service

Kendell Dickinson, U.S. Geological Survey

Uldis Jansons, Bureau of Mines

Helen Hankins, Bureau of Land Management

Linda Harris, U.S. Geological Survey (illustrator)

John Mulligan, Bureau of Mines

Thomas Pike, Alaska Department of Natural Resources

Katherine Reed, U.S. Geological Survey (editor)

James Riehle, U.S. Geological Survey

Horace Sanders, Bureau of Land Management

Robert Sorensen, Bureau of Land Management

Robert Putz, U.S. Fish and Wildlife Service

Richard Stenmark, National Park Service

Gary Stricker, U.S. Geological Survey

Gary Winkler, U.S. Geological Survey 


\section{Annual Report on}

\section{Alaska's Mineral Resources}

U.S. GEOLOGICAL SURVEY CIRCULAR 940

Prepared in cooperation with the Bureau of Mines, the Bureau of Land Management, the National Park Service, the U.S. Fish and Wildlife Service, the Department of Agriculture-Forest Service, and the Department of Energy As mandated by Section 1011 of the Alaska National Interest Lands Conservation Act, Public Law 96-487, of December 2, 1980 
United States Department of the Interior

WILLIAM P. CLARK, Secretary

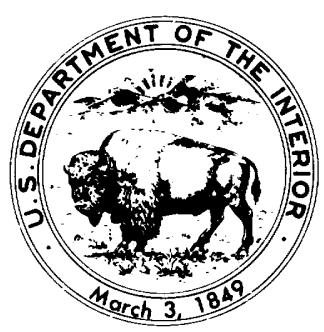

\section{Geological Survey}

Dallas L. Peck, Director 


\section{CONTENTS}

Executive summary............. 1

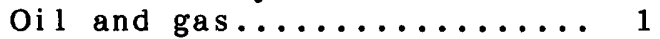

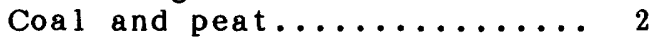

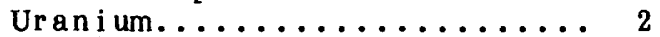

Geothermal energy.......... 2

Nonfuel minerals........... 2

Critical and strategic minerals............... 2

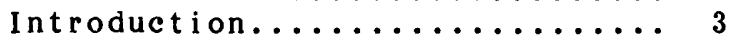

Department of the Interior... 3 U.S. Geological Survey... 3 Bureau of Mines........ 5 Bureau of Land Management.............. 5 National Park Service... 7 U.S. Fish and Wildife Service............ 8

Department of Agriculture-Forest Service........ 9

Department of Energy....... 9

Contacts for further

information.............. 9

oi 1 and gas....................

Activity by Federal

agencies in $1983 \ldots \ldots \ldots \ldots 10$

Industry activity in $1983 \ldots \ldots 15$

References cited........... 17

Urani um resources............. 17

Activity by Federal

agencies in $1983 \ldots \ldots \ldots 17$

Geothermal resources........... 17

Activity by Federal

agencies in $1983 \ldots \ldots \ldots \ldots 17$

state studies in $1983 \ldots \ldots \ldots 17$
Coal and peat............... 19 Activity by Federal

agencies in $1983 \ldots \ldots \ldots 19$

State activities in $1983 \ldots . .19$

Cooperative state and

Federal studies in $1983 \ldots 20$

Industry activities in 1983..20

References eited........... 21

Nonfuel minerals .............. 21

Activity by Federal

agencies in $1983 \ldots \ldots \ldots 23$

State activity in $1983 \ldots \ldots .28$

Industry activity in 1983... 29

References cited........... 37

Critical and Strategic minerals.. 37 Activity by Federal agencies in $1983 \ldots \ldots \ldots . \ldots 38$

Industry and state

activity in $1983 \ldots \ldots \ldots 38$

References cited.......... 40

Selected references............4 42

U.S. Geological Survey......43

Bureau of Mines...........448

Bureau of Land Management....49 U.S. Fish and Wild li fe

Service............... 49

National Park Service...... 50

Department of Agriculture--

Forest Service..........50

Department of Energy.......50

Other Federal agencies......50

Non-Federal publications.... 50

\section{ILLUSTRATIONS}

Figures 1-9. Maps showing:

Page

1. Distribution of National Interest Lands and conservation units established by the Alaska National Interest Lands

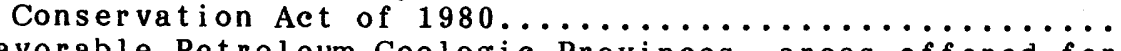

2. Favorable Petroleum Geologic Provinces, areas of ered for lease, Arctic National Wildlife Refuge study area, proposed

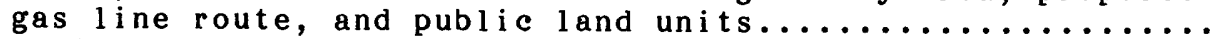

3. Location of exploratory wells drilled in $1983, \ldots$ il and gas fields, and Alaskan onshore and nearshore sedimentary

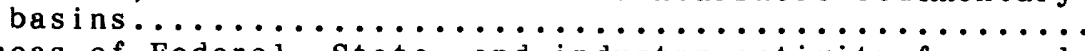

4. Areas of Federal, state, and industry activity or coal,

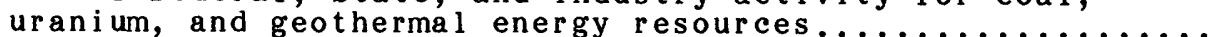


Figures (continued)

5. Locations of areas studied by the U.S. Geolgical Survey and the Bureau of Mines for nonfuel, critical and strategic

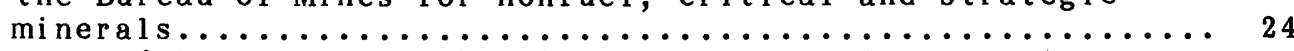

6. Status of Level II Alaska Mineral Resource Assessment Program studies, January $1,1984 \ldots \ldots \ldots \ldots \ldots \ldots \ldots \ldots \ldots \ldots{ }_{26} 6 \ldots \ldots \ldots$

7. Areas of important industrial activity for nonfuel

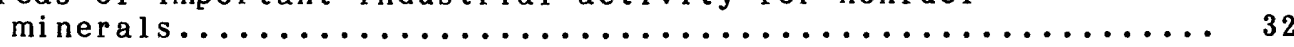

8. Areas of Bureau of Mines investigations for critical and strategic minerals in $1983 \ldots \ldots \ldots \ldots \ldots \ldots \ldots \ldots \ldots \ldots \ldots \ldots \ldots$

9. Areas of industrial activity for critical and strategic

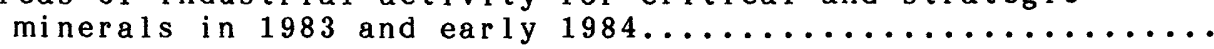

\section{TABLES}

Page

Table 1A. Onshore oil and gas leases sales, $1983 \ldots \ldots \ldots \ldots \ldots \ldots \ldots$

1B. Onshore oil and gas noncompetitive offering, $1983 \ldots \ldots \ldots \ldots 10$

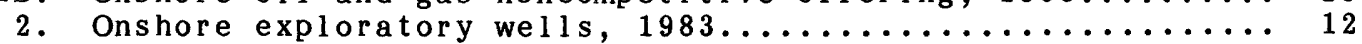

3. Mineral production in Alaska, $1982-83 \ldots \ldots \ldots \ldots \ldots \ldots \ldots \ldots 22$

4. Abbreviated titles or brief descriptions of projects whose study areas are shown in figure $5 \ldots \ldots \ldots \ldots \ldots \ldots \ldots \ldots \ldots 23$

5. Areas of industry activity for nonfuel minerals......... 32

6. Locality and prospect names to accompany figure $8 \ldots \ldots \ldots . . .40$

7. Localities of interest for critical and strategic minerals

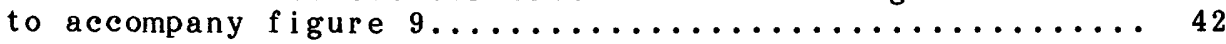




\section{Annual Report on Alaska's Mineral Resources, As Mandated by Section 1011 of the Alaska Nationa Interest Lands Conservation Act, Public Law 96-487, of December 2, 1980}

Prepared by the U.S. Geological Survey, in cooperation with the Bureau of Mines, the Bureau of Land Management, the National Park Service, the U.S. Fish and Wildlife Service, the Department of Agriculture-Forest Service, and the Department of Energy

\section{EXECUTIVE SUMMARY}

Section 1011 of the Alaska National Interest Lands Conservation Act requires that "On or before October 1, 1982, and annually thereafter, the President shall transmit to Congress all pertinent public information relating to minerals in Alaska gathered by the United States Geological Survey, the Bureau of Mines, and any other Federal agency." This is the third report to be prepared in response to that requirement.

This report addresses onshore areas of Alaska only. It provides information about minerals of current interest in two broad categories: energy resources and nonfuel, critical, and strategic minerals.

The Geological Survey and the Bureau of Mines are the principal Federal agencies that gather and publish information about mineral resources in Alaska. The report draws heavily on their work. Other sources of information include articles in trade and professional journals, symposia proceedings, talks at public meetings, and newspaper and magazine articles, as well as Federal and State publications.

\section{OIL AND GAS}

The State of Alaska ranked second among oilproducing States during 1983. The two petroleumproducing areas, the North Slope and Cook Inlet, provided a total of 626 million barrels of oil and 1.1 trillion cubic feet of dry and casinghead natural gas. These totals represent an increase of about one percent for oil and four percent for gas over 1982 totals. Alaska now provides about 20 percent of the United States production.

Industry onshore exploration and development drilling in Alaska in 1983 proceeded at a slower pace than in 1982. State and Federal agencies continued their designated regulatory functions and conducted lease sales and surveys relating to land classification and oil and gas resource evaluation.

Exploration activity included geological and geophysical surveys and drilling of 10 exploratory wells-eight on the North Slope, one in the Copper River basin in south-central Alaska, and one on Native lands in the Cook Inlet basin. Development activity included drilling about 180 new development wells in the Prudhoe Bay and Kuparuk fields and the continuation of enhanced oil recovery projects in both fields. Numerous other currently nonproducing North Slope fields were the subjects of feasibility studies.

Three competitive oil and gas lease sales were held in 1983-two by the State of Alaska and one by the Federal Government. Companies and groups of investors bid a total of $\$ 41$ million for about 1 million acres of land at these events. In addition, the Federal Government opened a total of 4.4 million acres in the Seward Peninsula to noncompetitive leasing.

The proposed Alaska Natural Gas Transportation System pipeline, intended to tap North Slope gas, remains stalemated by financial problems.

Federal agencies were again active in the National Petroleum Reserve in Alaska in 1983. The Bureau of Land Management held its third competitive lease sale, at which bids were received for about 420,000 acres. The U.S. Geological Survey continued to administer the Barrow gas fields. The Department of the Interior's negotiations on the transfer of the gas fields to the North Slope Borough were still under way at the close of the year.

Elsewhere in Alaska, Federal agencies were conducting oil and gas programs as required by ANILCA. The Bureau of Land Management and the 
U.S. Geological Survey continued their studies of oil and gas resources, wilderness characteristics, and wildlife resources in the the area east of the National Petroleum Reserve in Alaska north of latitude 68 degrees north for mineral leasing, including oil and gas. The Geological Survey began field studies to evaluate the petroleum potential of Alaska's interior basins.

\section{URANIUM RESOURCES}

As in previous years, low demand, large supplies, a generally low price, and high costs of logistics have combined to keep industrial activity for uranium in Alaska at a standstill. The Department of Energy released reports from its National Uranium Resource Evaluation program. The Geological Survey continued its fieldwork on the Seward Peninsula and in southeastern Alaska.

\section{GEOTHERMAL RESOURCES}

The State's geothermal resources continue to be used locally on a small scale, despite indications of a large energy potential near the widespread volcanic centers.

Drilling under contract to the Alaska Power Authority confirmed a steam reservoir on Makushin Volcano, and another drilling effort revealed the presence of possible heat sources on the Seward Peninsula and north of Anchorage. The Alaska Division of Geological and Geophysical Surveys has recently compiled statewide geothermal-resource data.

\section{COAL AND PEAT}

The Geological Survey concentrated its coal studies in two quadrangles on the North Slope and in the coal field west of Anchorage. The State of Alaska was formulating reclamation plans for formerly mined areas, compiling data for the Matanuska Valley coal area, and exploring coals in the northwest part of the State. The Bureau of Land Management and the State drilled coal beds in northern Alaska; preliminary results indicated reserves of at least 20 million tons that might be used locally.

Industry interest continued in the Beluga-Capps Glacier, Nenana, Jarvis Creek, Matanuska Valley, and Bering River coal fields. Preparations for shipping coal from the Nenana field to Korea made some progress. Federal institutions in interior Alaska will soon be using coal from this field. Elsewhere, feasibility, environmental, and mapping studies were under way.

Statewide, interest in peat as an energy source continued at a very low level. Primary peat use was in agriculture.

\section{NONFUEL MINERALS}

During 1983, development work on Alaska properties and exploration continued at or near 1982 levels. Nearly 28 percent fewer new mining claims were filed than in 1982, but this decrease was of fset by a 38-percent increase in the value of nonfuel mineral production. The chief commodities contributing to this value were sand and gravel, crushed stone, and gold. Prices for sand, gravel, and gold increased slightly in 1983. Alaska ranked 35th in nonfuel mineral production.

Placer gold mining is the major source of gold in the State, but meeting water-quality requirements statewide was emerging as a major issue in 1983.

The State Government continued to work toward methods of enhancing the minerals industry; it established a regional bonding authority and a Division of Mining, completed land exchanges to facilitate mining or transportation, and began work on reopening of fshore mineral exploration opportunities.

Federal agencies completed several cooperative projects: a minerals assessment of the Chugach National Forest lands, an evaluation of areas north of Mount McKinley, and a reconnaissance of the Iditarod-George Planning Block in western Alaska. Four million acres on or near the Seward Peninsula were opened for mineral claims. Planning for the Bristol Bay area was well along. The Geological Survey's Alaska Mineral Resource Assessment Program continued multidisciplinary studies in nearly 20 quadrangles across the State.

The development of the silver and base-metals deposit at Greens Creek near Juneau remains essentially on schedule; a major effort was directed at perfecting claims. Bulk sampling began at the Quartz Hill molybdenum deposit near Ketchikan, and environmental and facility siting studies continued. Additional lead-zinc reserves have been delineated at Red Dog, and a route from the deposit to tidewater has been arranged.

\section{CRITICAL AND STRATEGIC MINERALS}

The potential of promising resources of cobalt, chromium, nickel, tin, tungsten, and platinum-group elements in Alaska continues to be dampened by unfavorable land status, inadequate transportation, high cost of development, and remote markets. Exploration for tin continued, primarily on the Seward Peninsula and in central and southwestern Alaska, and tin production increased slightly relative to 1982. Southeastern Alaska remained the scene of considerable work on copper-cobalt-nickel deposits. Although a dredge was active in the Goodnews area, no platiunum-group metal production was reported.

Four Geological Survey projects continued to examine occurrences of critical and strategic minerals in central and western Alaska. The Bureau of Mines' statewide reconnaissance investigations of cobalt, chromium, and platinum-group element occurrences were expanded in 1983 to include tin, tantalum, and niobium. 


\title{
1984 Annual Report on Alaska's Mineral Resources,
}

\section{As Mandated by Section 1011 of the Alaska National}

\section{Interest Lands Conservation Act, Public Law 96-487, of December 2, 1980}

\author{
Prepared by the U.S. Geological Survey, in cooperation with the Bureau of Mines, the Bureau of Land \\ Management, the National Park Service, the U.S. Fish and Wildlife Service, the Department of \\ Agriculture-Forest Service, and the Department of Energy
}

\section{INTRODUCTION}

Section 1011 of the Alaska National Interest Lands Conservation Act (ANILCA) of 1980 requires that "On or before October 1, 1982, and annually thereafter, the President shall transmit to Congress all pertinent public information relating to minerals in Alaska gathered by the United States Geological Survey, Bureau of Mines, and any other Federal agency." The Geological Survey has been delegated the lead role in responding to this requirement. This circular is a synthesis of information made public in 1983 and early 1984.

This circular considers only onshore areas of Alaska; no information about the Outer Continental Shelf or maritime areas is included. Some information about offshore areas may, however, have been used in studies of onshore mineral occurrences. The report is organized according to types of mineral or energy resources, rather than presenting a region-by-region synopsis of mineralrelated activities in Alaska.

The Geological Survey and the Bureau of Mines are the principal Federal agencies that generate information about mineral resources in the State. Their information is used by many other agencies as basic sources for decision-related information about land use, access, environmental impacts, and, in some instances, claim evaluation. The results of studies, projects, and programs of the Survey and the Bureau therefore form the greater part of the material in this circular. Additionally, the State of Alaska's Division of Geological and Geophysical Surveys has contributed to this report.

As applied herein, the term "public information" includes the published results of Federal projects, either in Government reports or in professional and trade journals. Additional sources are talks by representatives of Federal and State agencies or industry at symposia, conferences, and other public forums, as well as in proceedings volumes, press releases, and newspaper and magazine articles.

Most Federal agencies' reports are published a year or more after data and sample collection. Thus, most of the material used to compile this report describes work done prior to 1983. However, information about current projects and programs is also included.

The report is structured around the two major categories of information, energy resources (oil and gas, uranium, geothermal resources, coal and peat) and nonfuel minerals, with emphasis on critical and strategic minerals. Although they are monetarily very significant in the State, sand and gravel and industrial minerals are not extensively discussed.

The next several pages describe the roles of land management and other Federal agencies as they relate to mineral information and activities. The distribution of ANILCA conservation units managed by Federal agencies is shown in figure 1.

\section{DEPARTMENT OF THE INTERIOR U.S. GEOLOGICAL SURVEY}

The U.S. Geological Survey was established to conduct systematic investigations of the geologic structure and mineral resources of the Nation. The Survey carries out its mission through topographic mapping; geologic, geochemical, and geophysical studies; stream measurements; geohazards resear ch; application of remote sensing techniques; and participation in multidisciplinary and interdepartmental studies and projects.

The Survey's role in assessing mineral resources has been increasing in the last few years, particularly in the area of energy resources. Field and laboratory research projects gather information 


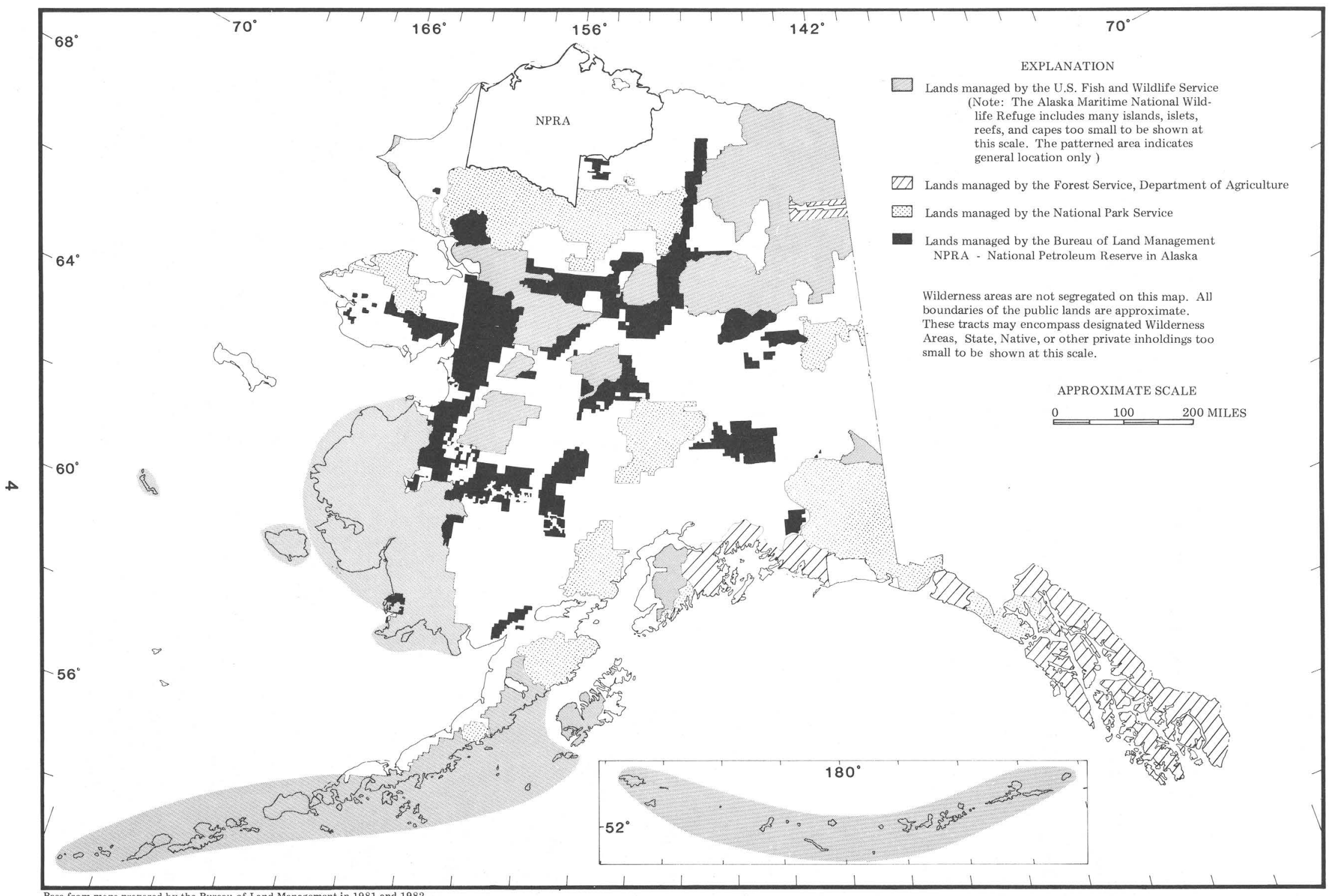

Figure 1.--Distribution of National Interest Lands and conservation units established by the Alaska National Interest Lands Conservation Act of 1980. Boundaries as of January 1984. 
about domestic petroleum, coal, uranium, and geothermal resources. In addition, Federal law requires that mineral assessments be made of areas to be set aside as wilderness and those established by ANILCA. The Alaska Mineral Resource Assessment Program (AMRAP, described more fully in the nonfuel minerals section of this circular) is an example of the Survey's response to such legislation. It has as its goal a systematic investigation of the State's resources. This program began in 1975 and investigates mineral resources at four progressively more detailed levels of study in many parts of the State. Levels I and II are the most general and cover the largest areas. Studies at Level III draw on many geologic disciplines to produce areal resource maps at a scales of $1: 125,000$ and $1: 250,000$. More than 25 such studies have been finished or are nearly complete. About 30 Level IV studies were under way in 1983; these are studies of individual mining districts, mineral deposits, or topics related to mineral deposit genesis. Products of such studies are usedto help determine our national mineral and energy endowment and aid in analyzing potential hazards or impacts. These studies also help industry locate and develop mineral deposits and assist in developing concepts, models, and techniques to identify nonfuel, critical, and strategic mineral deposits. Survey publications are commonly used by industry as a source of information about mineral deposits.

Several other Geological Survey programs were active in Alaska in 1983. Among these were (1) the Alaska Petroleum Program, consisting of six basin analysis projects, five on the North Slope and one in interior Alaska; (2) the Geologic Framework and Synthesis Program, whose basic research spans a broad spectrum of topics in geology, geochemistry, and geophysies; (3) the Earthquake Hazards Reduction program, a multi-agency program designed to mitigate losses through providing data and assessments for land-use planning, emergency preparedness, engineering designs, and warning of quakes; and (4) the Volcano Hazards program, emphasizing assessments and maps, monitoring, and basic research to enable scientists to predict time, location, and nature of eruptions. More information about these programs can be obtained from the Survey's Office of Mineral Resources in Reston, Va.

During 1983, the Geological Survey organized a multidisciplinary study, the Trans-Alaska Crustal Transect, or TACT. This project, which begins its activities in 1984, will investigate the structure and evolution of the Alaskan crust along a corridor paralleling the trans-Alaska pipeline and extending offshore across the Pacific and Arctic continental margins. Benefits of the study will be a better understanding of the relation between Alaska's geologic evolution and its mineral and petroleum potential, as well as increased knowlege of the earthquake and volcanic processes and the geologic hazards along the transect.
Along its 1,000-mile length, the TACT crosses a broad range of geologic structures, including an active subduction zone, accreted oceanic and continental microplates, sedimentary basins, largescale overthrust belts, a rifted continental margin, and a diverse array of major structural boundaries. The study will apply complementary geologic and geophysical methods, as well as integrate interpretation and synthesis of data.

TACT plans for 1984 include three groups of projects. (1) Seismic refraction/wide-angle reflection profiles will be run across the boundaries of the accreted Chugach, Wrangell, and Peninsular terranes in southern Alaska. (2) The geology of 20kilometer-wide strips along the seismic profiles will be mapped at $1: 63,360$ scale or larger, and detailed supplementary studies will characterize in detail the geology of the Chugach terrane and the suture between it and its neighboring terranes on the north. (3) Existing aeromagnetic and gravity data in 1-degree-wide bands along the seismic profiles will be compiled, corrected, and modelled, and some aeromagnetic data will be acquired in the southeastern part of the Gulkana quadrangle. Long-range planning for completing the transect will also be a priority activity.

The TACT study is being guided by a steering committee of representatives of four Geological Survey divisions. This committee is encouraging universities, industry, and other government agencies to collaborate in deep seismic-reflection profiling and to undertake complementary studies along the route.

In addition to the program activities briefly described above, the Geological Survey is often the lead agency in the preparation of environmental impact statements for areas where mineral-related activity is proposed.

The Geological Survey's Branch of Alaskan Geology has its headquarters in Anchorage and a field office in Fairbanks. Other branch geologists are stationed in Menlo Park, Calif. Alaskan seismic observatories are maintained in Adak, Barrow, Fairbanks, and Sitka.

\section{BUREAU OF MINES}

The Bureau's mission is to help assure that the Nation's mineral supplies are adequate to maintain national security, economic growth, and employment. The Bureau of Mines is represented in Alaska by the Field Operations Center with headquarters in Juneau and offices in Anchorage and Fairbanks. The Alaska Field Operations Center carries out the mission in six program areas:

(1) Minerals availability-This program is part of a worldwide Bureau of Mines program that relies on the Minerals Availability System (MAS) computer data base and the Mineral Industry Location System (MILS), a subset of MAS. MILS contains basic information 
about the indentification and location of known mineral deposits. MAS is more comprehensive, containing information about reserve estimates, mineral extraction and beneficiation methodologies, environmental constraints to mining, and production cost analyses for selected major mineral deposits. Data are obtained from private industry, Federal, State, and local agencies, and ongoing Bureau programs. A complex computer and communications system allows the mineral information to be stored, manipulated, and retrieved. Data may be retrieved as computer-plotted map overlays and printouts of MAS/MILS data. Recently developed computer programs enable rapid and uniform development of cost data for MAS mineral deposit evaluations. Selection of MILS data for a given land area is enhanced by the ability to digitize boundary information directly from maps and compare the digitized boundaries with MILS locations. MAS and MILS mineral deposit data are cross-indexed to several other minerals information data bases.

(2) Policy analysis-This relatively new program of the Bureau of Mines in Alaska emphasizes the analyses of newly developed and existing mineral data to interpret its significance relative to local and national mineral needs. Such studies include listing all known specific metal deposits and estimating the feasibility of mining them under present or foreseeable conditions. Land status maps are prepared to provide basic data for an interpretation of the significance of the land open or closed to mineral development. Another project is putting sample points and analytical results, principally from Bureau of Mines field projects, into a computerized format that will make it possible to retrieve the basic data for future re-interpretation.

(3) Land assessment-One of the Bureau of Mines' major programs in Alaska is the evaluation of mineral potential of Federal lands to aid Congress and the land-managing agencies in making management decisions. In 1983, a 4-year Roadless Area Resource Evaluation (RARE II) wilderness study done in cooperation with the U.S. Geological Survey was completed. Various Bureau reports are scheduled for release in 1984. A brief summary of results has been published in the Geological Survey's Professional Paper 1300 (Nelson and Jansons, 1984).

The Bureau of Mines also conducted two mineral studies in the Kantishna Hills and Dunkle Mine areas, now in the Denali National Park and Preserve. The first was to estimate the nature and extent of min- eralization; the second was to estimate mineral claim acquisition costs. These studies were mandated by section 2023 (b) of ANILCA. Private contractors were used to make both studies because of time constraints. Funds for the field studies were made available in the spring of 1983 . The recommendations were required to be presented within 3 years of the enactment of ANILCA, December 2, 1980. (See the nonfuel minerals section of this circular for more details.)

The Bureau of Mines also assisted the Bureau of Land Management by investigating the Iditarod-George Planning Block, in southwestern Alaska. The Federal Land Policy and Management Act and ANILCA mandate that the Bureau of Land Management identify the leasable, locatable, and salable minerals on these lands and use that information in the development of plans for subsequent use, disposition, or occupancy of the land. The Bureau of Mines obtained the information for this purpose mainly through literature study supplemented by a brief field program. The objective of the field program was to locate and identify reported mines, prospects, mineral occurrences, and mineralized areas.

(4) Critical and strategic minerals-This statewide program supplements the mineral land assessment program. Critical and strategic mineral deposits on Federal land closed to mineral entry by industry are investigated, as are deposits open to entry if they are not of current interest to private industry. Cooperative efforts with industry also have been undertaken. In addition to locating deposits and estimating size and grade, bulk samples are taken for metallurgical research to estimate recoverability and costs. These investigations should create a stockpile in the ground that can be used when needed.

(5) Mining research-Mining research is directly related to the mineral land assessment and the critical and strategic minerals programs. Various Bureau of Mines and university research centers cooperate with the Alaska Field Operations Center to solve mineral utilization problems. The Bureau has a continuing metallurgical research program concerned with critical and strategic minerals. Recent studies focused on potential chromium-bearing materials in south-central Alaska and on potential cobalt, nickel, and platinum-group metals in southeastern Alaska. A cooperative program with the University of Alaska is concerned with underground placer mining methods. In addition, the Bureau of Mines 
and the University of Alaska have for many years participated in the maintenance and use of a permafrost research center at Fox, near Fairbanks, in cooperation with the Corps of Engineers Cold Regions Research and Engineering Laboratory.

(6) State Minerals Specialist-The State Minerals Specialist cooperates with the Bureau's commodity experts in Washington, D.C., and with the State of Alaska's Division of Geological and Geophysical Surveys to collect and verify data about mineral activities and mineral production for periodic and annual reports, including the Bureau's Minerals Yearbook. The Alaska Field Office is a principal point of contact for the minerals industry, Federal and State agencies, and the public.

\section{BUREAU OF LAND MANAGEMENT}

The Bureau of Land Management is responsible for multiple-use management of the surface and subsurface of 23 million acres of the National Petroleum Reserve in Alaska (NPRA), 600,000 acres of the Central Aretic Management Area, and approximately 115 million acres of public lands south of Alaska's North Slope (fig. 1); the last figure includes substantial acreage encumbered through State and Native selections. Additionally, the Bureau of Land Management administers geothermal resources and leasable and locatable minerals on other Federal lands, including acquired lands, and on private lands where the Federal Government has retained mineral rights.

In December 1982, the Bureau of Land Management issued a mineral resources policy statement that reflects the Bureau's continuing commitment to encourage private enterprise in the development of the domestic minerals, consistent with the need for these resources. Public lands are generally to remain open to environmentally sound mineral exploration and development. Land-use planning will reflect energy and mineral values through geologic assessments. To reinforce the Bureau's mineral resource policy, the Secretary of the Interior, in December 1982, merged the onshore mineral and energy functions of the Minerals Management Service into the Bureau of Land Management. The result is a stronger minerals organization with significant restructuring of National, State, and district offices. The new organization has of fices for fluid minerals (oil and gas, geothermal resources; resource evaluations), for solid minerals (coal, oil shale, tar sand, and nonenergy leasable minerals), and for mining law and mineral assessment.

The Bureau of Land Management's administrative responsibilities for minerals require close coordination with other surface management agencies. Generally, in the case of upland, or onshore leases, the Bureau of Land Management issues leases and integrates the leasing with other land uses in cooperation with the surface management agency. After a lease is issued, the newly integrated minerals function assumes jurisdiction of exploratory and development activities in cooperation with the land manager to assure surface protection. The Bureau continues to develop a schedule for analysis to determine which lands not on the North Slope should be opened for mineral leasing.

The principal activities of the Bureau of Land Management that are related to Alaska's minerals and energy resources are (1) preparation for the scheduling of Federal oil and gas leases in the upland areas with the concurrence of the surface management agency, (2) organization and evaluation of Federal oil and gas leases, and (3) recordation of mining claims and determinations of the validity of mining claims for mineral patents. In the past, the Bureau of Land Management has rarely produced reports that pertain to the evaluation of mineral and energy resources; with the Minerals Management Service (onshore) merger, the Bureau of Land Management will be releasing reports about onshore mineral potential.

The Bureau of Land Management is responsible for enforcing the environmental and technical stipulations of the Agreement and Grant of Right of Way for the Trans-Alaska Pipeline System. The overall goal is to maintain a continuous supply of energy with minimum environmental impact. The Bureau is also charged with issuing land-use authorizations and conducting mineral and material sales to support preconstruction activities for the planned natural gas pipeline.

\section{NATIONAL PARK SERVICE}

The act establishing the National Park Service in 1919 (39 Stat 535) directed it $" * * *$ to consider the scenery and natural and historical objects and the wildlife $* * *$ and to provide for enjoyment of the same in such a manner and by such means as will leave them unimpaired for the enjoyment of future generations." Administrative policy is based on the principles of maintenance of the natural resources and on the concept that national interest dictates decisions affecting private or public enterprise in the parks. The Service currently has jurisdiction over an estimated 52 million acres of park lands in Alaska (fig. 1). Its main Alaskan office is in Anchorage.

Park Service responsibility for mining claims and mining on park lands in Alaska and elsewhere is basically limited to mineral examinations and determinations of valid existing rights, environmental assessments of the potential impacts of mining on natural and cultural resources on Federal or other lands, protection of park resources through mining plans developed under Federal regulations, and approval of mining plans of operation. The assessments and mining plans are available for public review. 
Except for validity determinations, the Service rarely collects or publishes basic data about mineral deposits, commonly relying on information gathered by claimants, the Geological Survey, the Bureau of Mines, or State or private sources. Validity determinations also involve the Bureau of Land Management and the Office of Appeals and Hearings. Results of mineral examinations are made public when decisions are final.

\section{U.S. FISH AND WILDLIFE SERVICE}

The mission of the Fish and Wildlife Service is to provide Federal leadership to conserve, protect, and enhance fish and wildlife and their habitats for the continuing benefit of people.

In Alaska, the Service seeks to accomplish this mission through a variety of programs that implement the provisions of the Endangered Species Act, Marine Mammals Protection Act, Fish and Wildlife Coordination Act, Rivers and Harbors Act, National Wildlife Refuge System Administration Act, various migratory bird laws, and other statutes. Direct activities under these laws include administration of 77 million acres of National Wildlife Refuges, fish and wildlife research, law enforcement, and review and habitat protection through agency comments on permit requests, environmental impact statements, and other items.

Under the provisions of ANILCA, 16 refuges (fig. 1) were created or enlarged to conserve fish and wildlife populations and their habitats, as well as other values. Except for valid rights existing at the time of establishment, these refuges are closed to entry and location under the mining laws. The refuges are open to entry under the leasing laws; however, they are closed to the mining of Federal coal by the Federal Coal Leasing Amendments Act of 1975 and closed to geothermal resource leasing by the Geothermal Steam Act of 1970 .

While many traditional values have been deemed appropriate for these refuges, other uses, including oil and gas leasing, will be permitted only when such activities are compatible with the purposes for which the refuges were established. The compatible uses will be determined through the Comprehensive Conservation Planning process currently under way for these refuges.

In 1983 the Arctic National Wildlife Refuge received a 971,800-acre addition from State of Alaska lands. Also being sought through Congressional approval is the further addition of a remaining 325,500 acres conterminous to that addition and existing refuge boundaries. On the Arctic coastal plain, Federal mining estate in 92,000 acres of Kaktovik village lands was deeded to the Arctic Slope Regional Corporation. In the St. Matthew Island unit of the Alaska Maritime National Wildlife Refuge, 4,110 acres (about 5 percent of the island) were exchanged with Cook Inlet Regional Corporation (CIRI), in return for a similar acreage added to the Yukon Delta and Kenai
National Wildlife Refuges. CIRI plans a base for oil and gas exploration on its conveyance, subject to environmental protection stipulations and with provisions that the land be restored and returned to Federal ownership after such use. However, this exchange is being contested in the courts by the Audubon Society and other organizations.

\section{DEPARTMENT OF AGRICULTURE-- FOREST SERVICE}

The mission of the Forest Service of the Department of Agriculture is to provide a continuing flow of natural resource goods, including mineral and energy resources, and services to help meet national needs and contribute to meeting such needs worldwide. The Forest Service's responsibility in regard to these resources is to encourage and support environmentally sound mineral enterprises on Federal lands under its jurisdiction, consistent with other surface resource values. Under authority of the Forest Service Organic Act, the Service administers regulations for the protection of surface resources from activities concerned with locatable minerals. In managing the use of these resources, it is the objective of the Service that adverse environmental impacts to surface and cultural features and values that might result from lawful prospecting, exploration, mining, and mineral processing operations be minimized or repaired. This is accomplished through the use of reasonable conditions that do not interfere with legitimate, well-planned mineral operations. The Forest Service provides research information and technology to help with postmining reclamation. Annually, the Forest Service in Alaska provides for the disposal of millions of tons of sand, gravel, and stone.

Under a Memorandum of Understanding with the Bureau of Land Management, the Forest Service provides joint administration of the general mining laws on National Forest System lands. An example of this joint responsibility is the recent patent issued to U.S. Borax for 32 mining claims at their Quartz Hill deposit. The Forest Service recommended issuance of this patent based upon favorable findings in the mineral report prepared by Forest Service mineral examiners.

The Forest Service cooperates with the Department of the Interior agencies, particularly the Bureau of Land Management, in issuing mineral leases and assuring mitigation of surface impacts from such activities. For example, in June 1983 the Service recommended to the Bureau issuance of 14 geothermal lease offers on Kruzof Island near Sitka. In addition, the Service plans to begin evaluation in 1984 of 48 oil and gas lease offers on the Copper River delta near Cordova.

The Forest Service cooperates with the State of Alaska and private sectors in development of energy and mineral resources on inholdings. One such inholding is the Bering River coal field, under 
consideration for possible development by Chugach Natives, Inc., and others in a consortium.

The Alaska Region of the Forest Service encompasses about 23 million acres. The Service's regional office is in Juneau. Offices for the Chugach Forest are in Anchorage, and for the Tongass Forest, in Juneau, Sitka, Ketchikan, and Petersburg.

\section{DEPARTMENT OF ENERGY}

The functions of the Department in Alaska are primarily in the areas of (1) administering the current petroleum acts and Congressional mandates relating to energy, (2) monitoring grants, and (3) overseeing contracts for studies of geothermal and uranium energy resources described in parts of this report. The Department has a field office in Anchorage.

The Department's National Uranium Resource Evaluation (NURE) program has moved into the report publication phase for its Alaskan work. Geologic map compilations, quadrangle evaluations, topical studies, and results of the Airborne Radiometric and Magnetic Surveys, Hydrogeochemical and Stream Sediment Reconnaissance studies cover areas of known production, ore reserves, and potential reserves. The 1983 releases are listed under the Department's heading at the back of this circular.

\section{CONTACTS FOR FURTHER INFORMATION}

Department of the Interior

Bureau of Land Management

Bureau of Mines

U.S. Fish and Wildl ife Service
U.S. Geological Survey

\author{
Mi chael Penfold, \\ State Di rector \\ Federal Building \\ 701 C Street \\ Anchorage, AK 99513
}

John Mulligan, Chief Alaska Field Operations Center

P.O. Box 550

Juneau, AK 99801

(Of $\mathrm{fices}$ in Anchorage and Fai rbanks may also be consul ted. )

Robert Putz, Regional Di rector 1011 East Tudor Road Anchorage, AK 99503-6119
Thomas Miller, Chief Branch of Alaskan Geology 4200 University Drive Anchorage, AK 99508-4667

$\begin{array}{cc}\text { National Park } & \text { Roger Contor, Regional } \\ \text { Service } & \text { Di rector } \\ & \text { Alaska Area Of ice } \\ & 2525 \text { Gambell Street } \\ & \text { Anchorage, AK } 99503\end{array}$

Department of Agriculture

$\begin{array}{ll}\text { Forest Service } & \text { Norman Day, Mineral } \\ & \text { Examiner, Alaska Region } \\ & \text { P.O. Box 1628 } \\ & \text { Juneau, AK } 99802\end{array}$

Department of Energy
Fred Chiei, Regional Representative Federal Building 701 C Street Anchorage, AK 99513

\section{OIL AND GAS}

In 1983 , as in the previous several years, oil and gas were the most valuable commodities produced in Alaska. Alaska's two oil-producing areas, the Aretic North Slope and Cook Inlet, provided a total of 626 million (42-gallon) barrels of oil, 198 billion cubic feet of dry natural gas, and 972 billion cubic feet of casinghead gas in 1983 . This represents an increase over 1982 of about one percent for oil and four percent for gas (Alaska Oil and Gas Conservation Commission, 1984, listed with references cited at the end of this section.) Production increases on the State of Alaska's North Slope leases more than offset production declines from the Cook Inlet area, so that the daily rate of oil production at the end of 1983 amounted to 1.71 million barrels, or about 20 percent of the United States daily production.

During 1983, Federal and State agencies conducted three onshore competitive oil and gas lease sales, opened about 4.4 million acres to noncompetitive oil and gas leasing, monitored and supervised lease development, collected rent on leases and royalties on production, and conducted numerous geologic and geophysical studies relating to oil and gas resource evaluation and land classification. These studies are only briefly reported in this circular; for Federal studies, the reader is directed to the most recent edition of the circular titled "The U.S. Geological Survey in AlaskaAccomplishments during (year) (listed with Survey reports at the back of this document), and for State activities, the State of Alaska quarterly report, "Alaska Mines and Geology." 
At competitive lease sales, a total of $\$ 40.8$ million was offered in high bids to acquire about 1.1 million acres for future exploration. Information about the lease sales and of ferings is summarized in tables 1A and 1B, and the lease sale areas are shown in figure 2 . The terms of the Federal leases are described in the following section about the Bureau of Land Management's activities. Terms of the State leases can be obtained from the Lease Administration Office, Alaska Department of Natural Resources, 555 Cordova Street, Anchorage, AK 99501.

Industry activity for onshore Alaska in 1983 included geophysical and geological surveys and drilling of 10 exploratory wells (table 2, fig. 3) and about 180 development wells in the two operating North Slope fields. Development drilling (about 170 wells) was concentrated primarily on the North Slope in the Prudhoe Bay and Kuparuk oil fields where enhanced oil recovery programs were also under way.

\section{ACTIVITY BY FEDERAL AGENCIES IN 1983}

U.S. Fish and Wildlife Service.-In keeping with its national mission, the primary efforts of the Service are in protection of fish, wildlife, and habitat both on the National Wildlife Refuge (NWR) system and on the remaining 80 percent of the State. However, petroleum-related activities took place on some of the refuges. On the Kenai NWR, oil production continued, and gas was produced on refuge lands in the Beaver Creek field. Exploratory drilling also took place, with one deep test well completed (Wolf Lake, shown on fig. 3 as well no. 10 ), albeit unsuccessfully, and another drilled about half way to its target of 19,000 feet. Special use permits were issued for petroleum-related work on the Alaska Peninsula, Becharof, Nowitna, Selawik, Yukon Delta, and Yukon Flats NW Rs.

Section 1002 of ANILCA mandates that an assessment be made of the fish and wildlife resources of the coastal plain of the Arctic NWR
Table 1B.- Onshore oil and gas noncompetitive offering, 1983

\begin{tabular}{|llll|}
\hline $\begin{array}{l}\text { Area } \\
\text { no. }\end{array}$ & $\begin{array}{c}\text { Area } \\
\text { opened }\end{array}$ & $\begin{array}{c}\text { Opening } \\
\text { date }\end{array}$ & $\begin{array}{c}\text { Acres } \\
(\mathrm{x} 1000)\end{array}$ \\
\hline 3 & $\begin{array}{c}\text { Seward } \\
\text { Peninsula }\end{array}$ & $11 / 9$ & 4,400 \\
\hline
\end{tabular}

and that potential impacts of oil and gas exploration, development, and production be analyzed. Accordingly, the act authorized a baseline study (Section 1002(c)) of biological and other resources and, in Section 1002(d), called for limited petroleum exploration of the refuge's coastal plain. Exploration is limited to surface geological and geophysical studies and does not allow exploratory drilling. The program is structured to allow private industry to gather data about the petroleum potential of the area; the data will then be submitted to the Department of the Interior for analysis. The assessment of the oil and gas resources of the coastal plain is to be contained in a report to Congress to be submitted not later than September 2, 1986. The Fish and Wildlife Service is the overall coordinator of the resource assessment. The agency has entered into a three-way Memorandum of Understanding with the Bureau of Land Management and the U.S. Geological Survey; the latter agencies have the technical responsibility for determining the oil and gas potential of the refuge. (Further information about the roles of other Federal agencies in this effort is given in the sections describing the activities of the Bureau of Land Management and U.S. Geological Survey, below.)

In early 1983, the final environmental impact statement and regulations governing exploration of the refuge were published. The regulations pre-

Table 1A.- Onshore oil and gas lease sales, 1983 (see fig. 2)

\begin{tabular}{|c|c|c|c|c|c|}
\hline $\begin{array}{l}\text { Area } \\
\text { no. }\end{array}$ & Sale and number & Sale date & $\begin{array}{l}\text { Acreage } \\
\text { offered } \\
(x \quad 1000)\end{array}$ & $\begin{array}{l}\text { Acreage } \\
\text { bid on } \\
(x 1000)\end{array}$ & $\begin{array}{l}\text { Total high } \\
\text { bids (millions } \\
\text { of dollars) }\end{array}$ \\
\hline $\begin{array}{l}1 \\
2 \\
4\end{array}$ & $\begin{array}{l}\text { NPRA, No. } 831^{1} \\
\text { Beaufort Sea, No. } 39^{2} \\
\text { Upper Cook Inlet, No. } 40\end{array}$ & $\begin{array}{l}7 / 20 \\
5 / 17 \\
9 / 28\end{array}$ & $\begin{array}{r}2,196 \\
2123 \\
1,056^{4}\end{array}$ & $\begin{array}{l}419 \\
212 \\
436\end{array}$ & $\begin{array}{r}16.7 \\
20.9 \\
3.2\end{array}$ \\
\hline
\end{tabular}




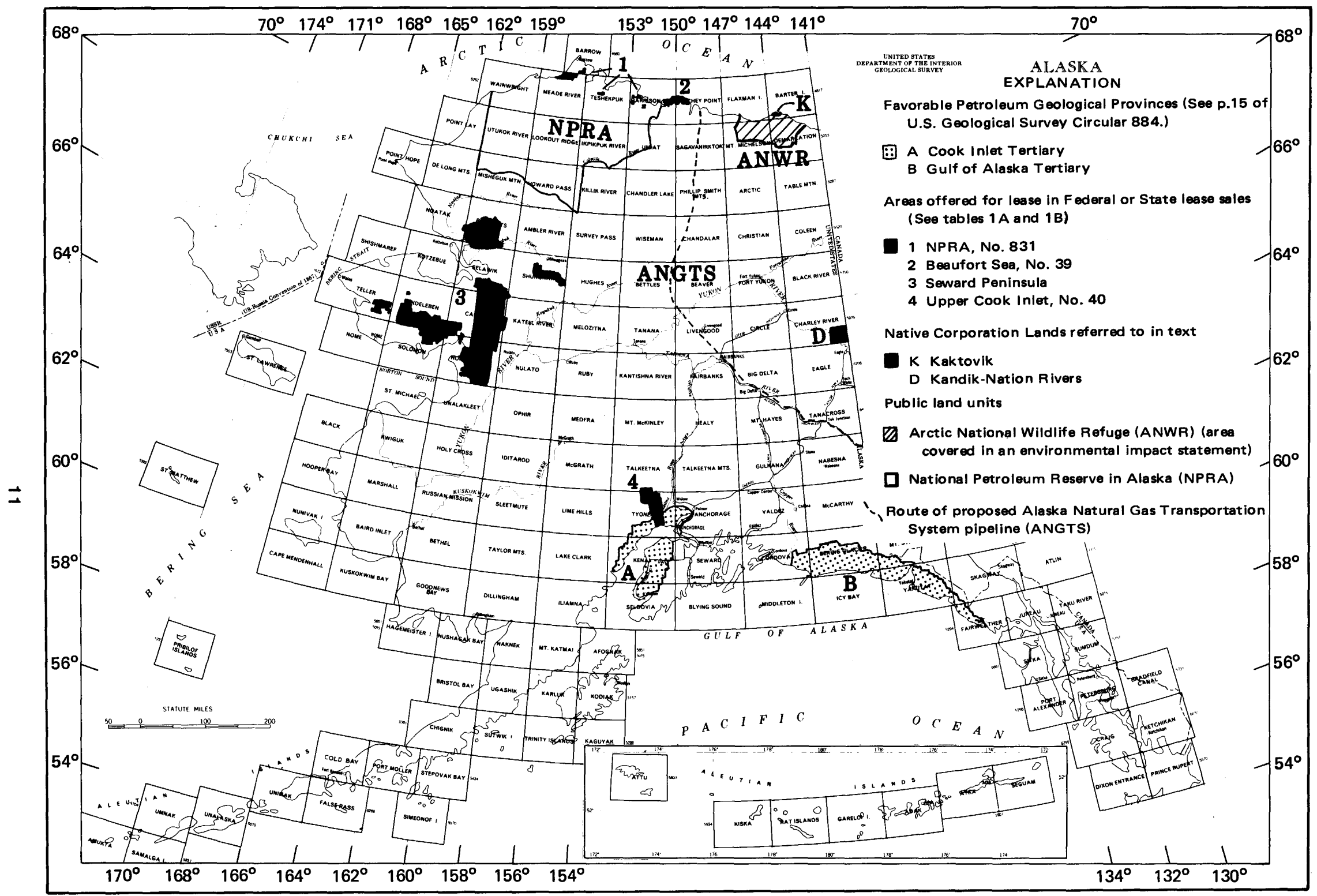

Figure 2.--Favorable Petroleum Geological Provinces (FPGP), areas offered for lease, Arctic National Wildlife Refuge study area, proposed gas pipeline route, and public land units. 
Table 2.-- Onshore exploratory wells, 1983 (see fig. 3)

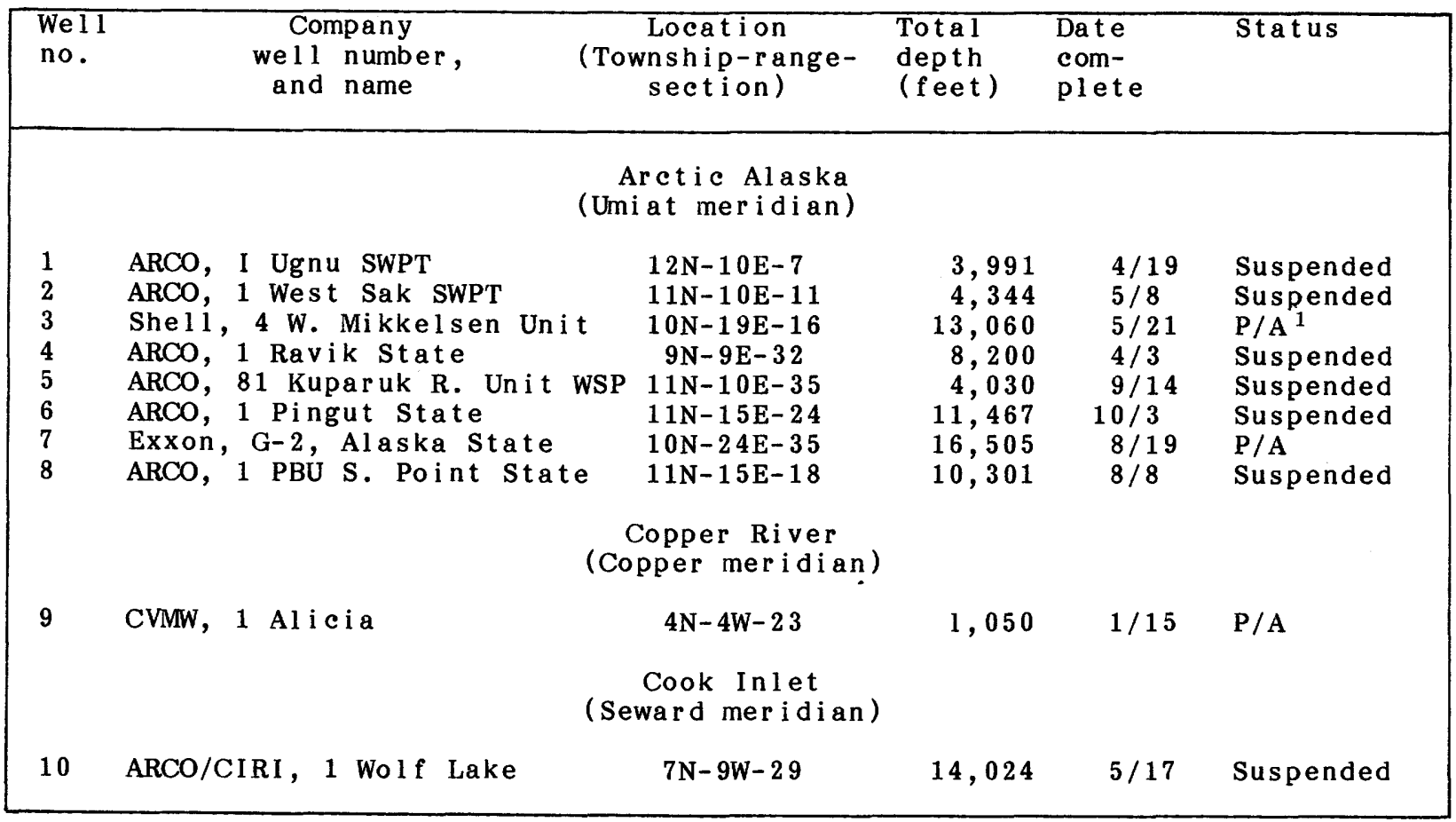

\footnotetext{
${ }^{1}$ Plugged and abandoned
}

scribe requirements and procedures for the authorization and conduct of exploration activities.

Industry plans for exploration on the coastal plain were submitted in May 1983: ten for surface geology, eight for seismic work, and one for a gravity/magnetic/photo-geology survey using doppler satellite and inertial survey techniques. All ten surface geology plans were approved, and most exploration began during the summer. The gravity/magnetic/photo-geology plan was approved, with a modification to permit grid coverage of 1 by 2 miles, a reduction from the proposed 1 by 1 mile. The survey was completed in October. Of the eight seismic plans, only one was approved, thereby eliminating what was felt to be unnecessary duplication of effort and significant adverse impacts to fish and wildlife. The plan approved was submitted by Geophysical Services Inc. (GSI). A condition attached to approval of the GSI plan was that interested parties be provided a chance to participate in the exploratory activities. GSI's plan was modified to require an explosive (dynamite) energy source in shallow drill holes instead of a surface-mounted mechanical vibrator energy source and to limit the seismic grid to 6 by 12 miles, a reduction from the proposed 2 by 2 mile grid.

The Fish and Wildlife Service felt that a general reconnaissance grid of 6 by 12 miles the first year (with the option of allowing more detailed infill surveys during subsequent seasons) would best provide the data necessary for the Secretary's report to Congress while protecting refuge resources. The seismic work started in January 1984.

Section 1008n of ANILCA calls for establishing an oil and gas leasing program for lands south of latitude 68 degrees north, pursuant to the Mineral Leasing Act (MLA) of 1920, as amended. This program would not apply to NWRs where the Secretary of the Interior determines that exploration or development of petroleum resources would be incompatible with the purposes of the refuge, after having considered the national interest in those resources. Section $304(\mathrm{~g})$ of the MLA cites the comprehensive conservation planning process as a means of identifying parts of NWRs where petroleum leasing or other activities would be incompatible with the purpose of the refuge. During 1983, planning again focused on the Kenai NWR, and, through the Bristol Bay Cooperative Planning Study, the Alaska Peninsula, Becharof, Izembek, and Togiak NWRs. These plans are scheduled for completion in 1984. Plans for all other Alaskan NWRs will be finished by 1987 .

If refuge lands are to be leased by the Bureau of Land Management, such leases will be competitive if located in a favorable petroleum geologic province or noncompetitive if not so located. All 


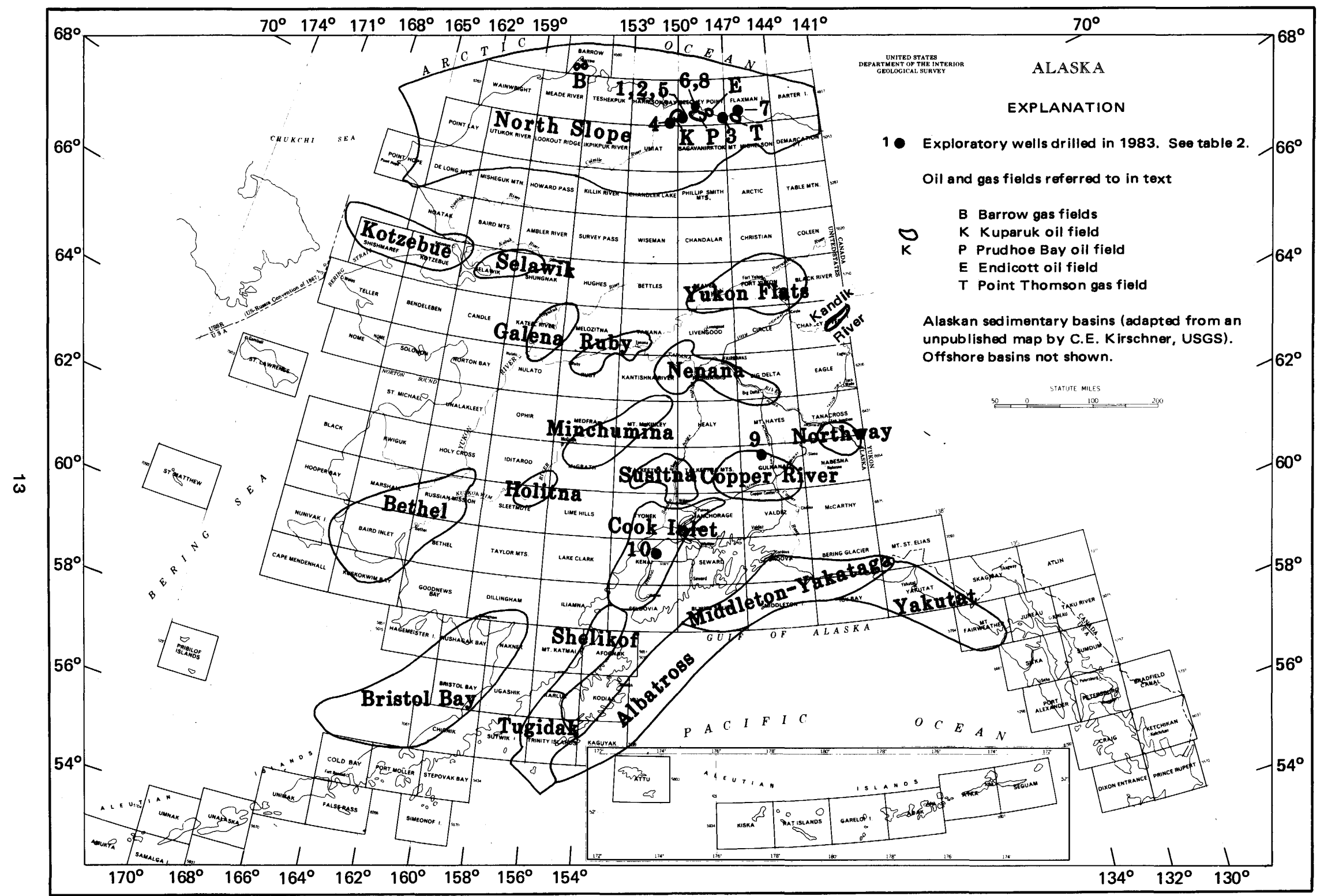

Figure 3.--Location of exploratory wells drilled in 1983, oil and gas fields, and Alaskan onshore and nearshore sedimentary basins. 
leasing, exploration, or production would be subject to permits and stipulations designed to protect fish, wildlife, and local subsistence activities. All activities will be subject to National Environmental Policy Act regulations.

The Fish and Wildlife Service activities in the Prudhoe Bay and Kuparuk oilfields on State lands between the Colville and Canning Rivers are related to the Corps of Engineers permit program under the Clean Water Act. By review and comment on proposed actions, adverse impacts to fish and wildlife habitat can be mitigated. Significant knowlege and progress evolving here will have applicability on the National Petroleum Reserve in Alaska (NPRA), the coastal plain of the Arctic NWR, and perhaps elsewhere in Alaska.

Bureau of Land Management.-The Bureau of Land Management is responsible for all mineral leasing of public domain or acquired lands, regardless of which agency is designated as surface manager. This includes fair market value determinations based on analysis of all available geological, geophysical, engineering, and economic data. It also includes responsibility for inspection and enforcement actions on exploration and development operations on leases.

The Bureau in Alaska has an automated filing and recordation system for locatable and leasable minerals. As a consequence, all filings are now entered into the Alaska Automated Land Records System (AALRS). A computer-generated abstract is available in the Alaska State of fice in Anchorage and the Anchorage and Fairbanks district offices. The file includes a history of actions and a complete description of the lands applied for in an oil and gas offer to lease, lands rejected, and lands under lease, as well as other information.

A Memorandum of Understanding involving the Governor of Alaska, the Bureau of Land Management, the Regional Forester for the Department of Agriculture, and the Undersecretary for the Department of the Interior was signed in May 1982. The memorandum established a mutually approved schedule to study areas prior to oil and gas lease offerings and identified key contacts in the State and Federal of fices to facilitate exchange of information and review. It also confirmed a commitment to cooperate on land-use planning.

Under terms of the Memorandum of Understanding among the Bureau, the Geological Survey, and the U.S. Fish and Wildlife Service regarding the resource assessment of the Arctic NWR, the Bureau's responsibilities include the following: (1) The Bureau will provide two technical experts knowledgeable in all aspects of geological and geophysical exploration practices to serve on the interagency panel for reviewing the technical accuracy of the industry exploration proposals; (2) the Bureau will, if necessary, provide technically qualified field monitors to accompany industry crews to assure the quality of the geological and geophysical data acquired by the permittees; (3) the Bureau will receive from the Fish and Wildlife Service all oil and gas resource data generated by the industry programs and will assume responsibility for its storage, handling, and security; (4) the Bureau will interpret and analyze all available geologic, geophysical, engineering, and economic data in order to provide the Fish and Wildlife Service with information needed to complete the assessments identified in ANILCA Sections 1002 (h) (1), (4), (5), and (6); and (5) the Bureau will assist the Fish and Wildlife Service in preparing appropriate sections of the Secretary's report to Congress.

In establishing and implementing an oil and gas leasing program as required by Section 1008 of ANILCA, the Bureau of Land Management has conducted noncompetitive lease offerings in three areas south of 68 degrees north. (Figure 2 shows the area offered in 1983). The Minchumina area was opened in 1981, and the Denali-Tiekel area was opened in 1982; as of December 31, 1983, about 248,000 acres of the Minchumina area and 1.9 million acres of the Denali-Tiekel area were under lease. About 4.4 million acres on the Seward Peninsula were opened in September 1983. According to Petroleum Information's Alaska Report of November 30, 1983, nearly 100 applications for the leases on the Seward Peninsula had been received by November 25 . These will be processed in 1984 . No major changes in the Bureau's noncompetitive lease lottery program have yet resulted from a national review of this program.

The third competitive lease sale in the NPRA was held July 20, 1983 . Approximately 2,195,840 acres were offered, and 419,618 received bids. High bids totalled $\$ 16,122,146$. The Bureau's royalty rate was set at $162 / 3$ percent, with a cash bonus. Leases were being issued in January 1984.

The Bureau announced plans for two future lease events. One will be the fourth NPRA oil and gas lease sale in July 1984 to include about 1.6 million acres. The second will be noncompetitive oil, gas, and mineral lease offerings of about 8 million acres in central Alaska (fig. 3). Public hearings on the latter were scheduled for winter 1983-84.

The opening of the "corridor" lands along the oil pipeline awaits conclusion of negotiations between State and Federal agencies and the Native corporations.

The Annual Report of the Bureau's Branch of Pipeline Monitoring is available through the Public Affairs Office in the Anchorage Federal Building. The Branch, which assures that terms and conditions of the Alyeska Pipeline Service Company's land use agreement are met, reports directly to the Division of Mineral Resources.

The Northwest Alaskan Pipeline Company, which proposes to build a second large pipeline, has again delayed its schedule of activity. As a result, the Bureau's involvement with this project is at a low level. 
U.S. Geological Survey.-The North Slope continues to be the focus of most Geological Survey studies related to onshore oil and gas resources. These and other studies are highlighted below.

* The operational phase of the Federal petroleum exploration program in the NPRA was completed in 1981. More than 30 reports by Survey scientists are in final stages of completion for publication as a Geological Survey Professional Paper. Topics to be included are stratigraphy, sedimentation, seismic stratigraphy, petrography, paleontology, biostratigraphy, petroleum source-rock geochemistry, structural geology, direct hydrocarbon detection by aeromagnetic and helium methods, assessment results, and exploration history. Most data from the 1974-81 exploration program, as well as numerous pertinent contractor reports, are available to the public through the National Geophysical and Solar-Terrestrial Data Center, Boulder, CO 80303. Their catalog itemizes information about 38 wells, 14,770 line-miles of reflection seismic surveys, 52,000 gravity measurements, and numerous reports about geology, geophysies, the environment, construction, and logisties.

* Negotiations between the Department of the Interior and the North Slope Borough continued on the transfer of control of the Barrow gas fields (fig. 3) from the Department of the Interior to the North Slope Borough. The two fields are currently administered by the Geological Survey.

* Framework geologic studies continue for the area east of the NPRA, the Central Arctic Management Area, and the Aretic National Wildlife Refuge. Reports issued in 1983 for these areas and the NPRA include information about depositional relations of Tertiary and Cretaceous rocks (Molenaar, 1983); abstracts of the results of geochemical analyses of oil and potential source rocks by 30 research groups from around the world (Magoon and Claypool, 1983); new information about the Umiat oil field (Molenaar, 1982); a structural synthesis of the central and western Brooks Range (Mayfield and others, 1983); the seismic stratigraphy framework of the NPRA (Kirschner and others, 1983), and abstracts of talks about North Slope structure, stratigraphy, geochemistry, paleontology, and nonfuel mineral resources (U.S. Geological Survey Circular 911).

* A proposal to study natural gas hydrates on the North Slope was submitted to the Department of Energy in 1983. The study, to begin in 1984 and last 3 years, has as its primary goal a detailed examination of data from northern Alas$k a$ about known gas hydrate occurrences and the synthesis of a model for their formation and occurrences. Ultimately, the work will lead to a series of gas-hydrate resource assessments.
* The Memorandum of Understanding (MOU) signed in mid-1983 under Section 1002 of ANILCA among the Fish and Wildlife Service, the Bureau of Land Management, and the U.S. Geological Survey identifies the Geological Survey as having the lead role in providing assistance to the Fish and Wildlife Service in completing the oil and gas assessment part of the Secretary's report to Congress. The MOU allows the Survey to conduct geological or geophysical studies that are determined by the Fish and Wildlife Service's regional director to be necessary in preparing an adequate report. The Survey has designed an oil and gas investigation program that will provide a credible, publicly defensible oil and gas assessment of the coastal plain of the refuge. This program will integrate the industry-acquired seismic and surface geological data with topical oil and gas investigations by Survey scientists.

* Geological Survey scientists conducted a project whose goal is to summarize and evaluate the petroleum potential of all interior Alaska basins (those south of the North Slope and generally north of Cook Inlet as shown on fig. 3 ) and published their first reports during 1983. A one-month helicopter-supported field program measured gravity and magnetic properties, and stratigraphic studies were carried on in the Nenana basin and the Yukon Flats basin-Kandik fold belt. Geologic literature, geophysical and well data pertaining to these interior basins are summarized in Di Bona and Kirschner (1984). Additional fieldwork is planned for 1984. Geologists with the State of Alaska conducted geologic and geophysical surveys in the Minchumina and Holitna basins during 1983.

\section{INDUSTRY ACTIVITY IN 1983}

Industry exploration and production activity in Alaska during 1983 was directed to both onshore and of fshore areas. Summaries of these activities have been published in Petroleum Information's Alaska Report for Jan. 11, 1984, and the Oil and Gas Journal issue for June 27, 1983. Only the highlights of onshore activities are summarized below.

* The compilation of industry surface geologic investigations is generally obtained from private scouting services, and statistics are normally released late in the year following the work. However, information for 1982 has not been reported and thus is not yet available. (See Jones, 1983.)

* Data for 1983 industry geophysical surveys is also obtained from private scouting services and will not be available until late in 1984 . During 1983, however, information about 1982 activity was published (Jones, 1983). In 1982, onshore geophysical surveys consisted of $\mathbf{8 5}$ field-crew months, a 30-percent increase over 
1981. These surveys were conducted mostly on the North Slope.

* Seven companies and one Alaskan Native corporation drilled 10 onshore exploratory wells in 1983, as compared to 13 in 1982 and 14 in 1981. Eight of these wells are on the North Slope, one is in the Copper River basin, and one is in the Cook Inlet basin (table 2). Few data from these wells have been released. Several of the North Slope wells were drilled near known oil fields and have been suspended (as reported in several issues of Petroleum Information's Alaska Report).

* Most major oil companies, many smaller oil companies, and several brokers representing hundreds of individuals participated in one or more of the three competitive lease sales in 1983. They offered about $\$ 40$ million in high bids for about 1 million acres of land (table $1 \mathrm{~A}$ ).

* Oil companies announced two new exploration agreements with Alaskan Native corporations, and another agreement was renewed in 1983. On the North Slope, Chevron USA, Sohio, and BP Alaska reached agreement with the Arctic Slope Regional Corporation to explore 92,000 acres under Kaktovik village lands in the Arctic National Wildlife Refuge. The Native corporation acquired title to this land in an exchange with the Department of the Interior for inholdings in the Gates of the Arctic National Park. Under the land exchange agreement, as many as three exploratory wells may be drilled on this acreage, but no oil development is possible unless and until Congress opens the refuge to leasing. In early 1984, the companies were engaged in a winter seismic survey.

In eastern Alaska, ARCO completed an agreement for 7 years' exclusive exploration rights on 386,000 acres of Doyon Limited land in the Kandik-Nation Rivers area (fig. 2).

Also in central Alaska, the village of Venetie agreed to extend an expiring exploration agreement with Rougeot Oil Company involving about 400,000 acres in the Kandik area (fig. 2) (Petroleum Information, Alaska Report, June 22, 1983).

* The three-billionth barrel of Prudhoe Bay oil entered the Trans Alaska Pipeline on August 18, 1983. This represents nearly one third of the 9.6 billion barrels of recoverable reserves in the field. Production in late 1983 amounted to about 1.5 millions barrels per day. The 1983 summer sealift successfully delivered equipment that will enable a waterflood project to begin in 1984. Injection of seawater and subsurface water into the reservoir is necessary to recover the 9.6 billion barrels of recoverable oil (about 40 percent of the oil in place) (Alaska Journal of Commerce and Pacific Rim Reporter, Aug. 29, 1983). In order to lessen or postpone the expected 1986 or 1987 initial decline in Prudhoe production, studies continue to evaluate the performance of ARCO's miscible gas injection project that began in 1982 . Various studies show that miscible gas drive would recover an additional 8.3 percent of the original oil in several areas amenable to these processes (Oil and Gas Journal, April 18, 1983).

* Oil production from the Kuparuk field in 1983 averaged 109,000 barrels per day, approximately 23 percent more than in 1982. Production rates were limited by ARCO's capacity to handle the natural gas associated with the oil. Currently, about 100 million cubic feet per day of gas is reinjected to the reservoir. Approximately $\mathbf{7 0}$ production wells were drilled in this field in 1983, and more than 725 wells will be needed to completely develop the field.

* During 1983, oil companies conducted numerous studies of other, nonproducing North Slope oil and gas fields to determine the feasibility of commercial development. Decisions are expected on many of these fields in 1984. These include (1) a pilot project that involves injection of hot water into the multi-billion barrel heavy oil accumulation in the shallow sandstones overlying the Kuparuk oil field, (2) the Milne Point field, with reserves of $\mathbf{1 0 0}$ million barrels in the same reservoir as the Kuparuk field, (3) the Gwydyr Bay accumulation just north of the Prudhoe Bay field and in the same reservoir, (4) the Lisburne oil pool in carbonate reservoirs that underlie the Prudhoe field, (5) the Endicott reservoir with about 1 billion barrels of oil in place that lies mostly offshore just east of Prudhoe Bay, and (6) the Point Thomson field that lies both onshore and offshore just west of the Arctic National Wildife Refuge.

* The seismic survey plans of Geophysical Services, Inc., a subsidiary of Texas Instruments, were selected over those of seven other companies by the U.S. Fish and Wildlife Service for studying the coastal plain part of the Arctic National Wildlife Refuge. This survey, to begin in early 1984, is the first to be allowed in the refuge, and it is expected to provide more detailed information about the petroleum potential than that previously available from surface studies alone. These seismic data will provide the basis for a new oil and gas assessment of the area to be carried on by the Geological Survey and the Bureau of Land Management under terms of a three-party memorandum of understanding with the U.S. Fish and Wildlife Service.

* The proposed Alaska Natural Gas Transportation System (ANGTS, fig. 2) pipeline to tap natural gas in the Prudhoe Bay field continues to be hampered by financial problems. Chief roadblocks are a lack of a market for the gas and the difficulty of obtaining $\$ 40$ billion (in 1989 dollars) to finance this project. However, engi- 
neering studies are continuing and, by early 1984,60 to 70 percent of those studies had been completed at a cost of $\$ 700$ million (Oil and Gas Journal, v. 81, no. 26, p. 77).

\section{REFERENCES CITED}

Alaska Oil and Gas Conservation Commission, 1984, 1983 Statistical Report : 208 p. (published by the State of Alaska Oil and Gas Conservation Commission, 3001 Porcupine Drive, Anchorage, AK 199501).

Alaska Mines and Geology, published quarterly by the State of Alaska Department of Natural Resources, P.O. Box 80007, College, AK 99708.

Di Bona, P. A., and Kirschner, C. E., 1984 Geologic bibliography for selected onshore sedimentary basins of central and southern Alaska, addressing basin analysis and including an index of publicly available well and subsurface data: U.S. Geological Survey Open-File Report 84-99, 70 p.

Jones, B. C., 1983, Oil and gas developments in Alaska: Oil and Gas Journal, published by Pennwell Publishing Co., 1421 South Sheridan Road, Box 1260, Tulsa, OK 74101.

Petroleum Information, Alaska Report, published by Petroleum Information Corp., a subsidiary of A. C. Nielsen, P. O. Box 102278, Anchorage, AK 99510.

\section{URANIUM RESOURCES}

Little uranium exploration was carried out in the United States during 1983 because of low demand and large supplies. Although the future of uranium is clouded, the price of uranium rebounded slightly from a low of about $\$ 17.00$ per pound in 1982 to about $\$ 22.00$ per pound in late 1983. High exploration costs continue to be an obstacle to uranium exploration in Alaska.

\section{ACTIVITY BY FEDERAL AGENCIES IN 1983}

Department of Energy.-The Department of Energy continued to release uranium reports about areas of Alaska. Some reports released in 1983 are recently declassified reports prepared during the 1950 s, and some are the products of the recently completed National Uranium Resource Evaluation program. The 1983 releases are listed under the Department's heading at the back of this circular.

U.S. Geological Survey.--During 1983, fieldwork on an epigenetic uranium deposit south of Death Valley, on the eastern Seward Peninsula, was combined with a coal reconnaissance study. Laboratory studies of the uranium samples collected are under way. Studies of the uranium potential of the northern part of the Admiralty Trough in southeastern Alaska and of the Nenana coal field in central Alaska are in progress and will be supported by fieldwork during 1984. Locations of the areas studied are shown in figure 4.

\section{GEOTHERMAL RESOURCES}

Alaska's geothermal resources are used only locally and on a small scale for recreational purposes, space heating, and agriculture. However, the widespread volcanic centers and activity in the State suggest a large geothermal energy potential. Development of this energy is likely where markets occur-for example, fishing ports in the Aleutian Islands or near transportation corridors near the Wrangell Mountains.

\section{ACTIVITY BY FEDERAL AGENCIES IN 1983}

U.S. Fish and Wildlife Service.-Although the Geothermal Steam Act of 1970 closed wildlife refuges to geothermal leasing, the Fish and Wildlife Service permitted Alaska Maritime National Wildlife Refuge lands to be used for evaluation of the resource on the east flank of Makushin Volcano on Unalaska Island in the eastern Aleutian Islands (fig. 4). Further details of this work are given below.

U.S. Geological Survey.-The Geological Survey continued to assess the heat content and geothermal potential of volcanic heat reservoirs on the Alaska Peninsula, particularly the volcanic centers in the Ugashik quadrangle (fig. 4).

\section{STATE STUDIES IN 1983}

Republic Geothermal, Inc., under a \$4.7-million grant awarded early in 1982 by the Alaska Power Authority, has conducted a program comprising geologic and geophysical surveys and drilling on the flanks of Makushin Volcano (fig. 4). Temperatures of $393^{\circ} \mathrm{F}\left(195^{\circ} \mathrm{C}\right)$ were measured in 1982 at a depth of 485 feet. In 1983 , steam was confirmed at a depth of 1,940 feet; its temperature was $379^{\circ} \mathrm{F}$ or $195^{\circ}$ C. Brief testing of the single drill hole suggested a potential capacity of 5 megawatts per well for wells that might be drilled. Activities planned for 1984 include more extensive testing of the existing hole, additional drilling to better determine the subsurface temperatures, and a preliminary assessment of the feasibility for use of the resource as an alternative power source at Dutch Harbor.

Drilling in 1982 at Pilgrim Springs, 90 miles west of Nome on the Seward Peninsula (fig. 4), confirmed a shallow reservoir that has a temperature of $200^{\circ} \mathrm{F}$ or $95^{\circ} \mathrm{C}$ at depths of 75-125 feet. Follow-up studies in 1983 comprised sampling of geothermal fluids by the Alaska Division of Geological and Geophysical Surveys (DGGS). The newly created Office of Energy in the Alaska Department of Commerce is the lead agency for any further State development in this area.

Preliminary investigations of geothermal resources in the lower Susitna Basin near Willow (fig. 4) were completed by the University of Alaska's Geophysical Institute in 1982. Results of follow-up studies completed in 1983 , as well as of other preliminary studies by the Geophysical Institute and DGGS in the area between Mount Drum 


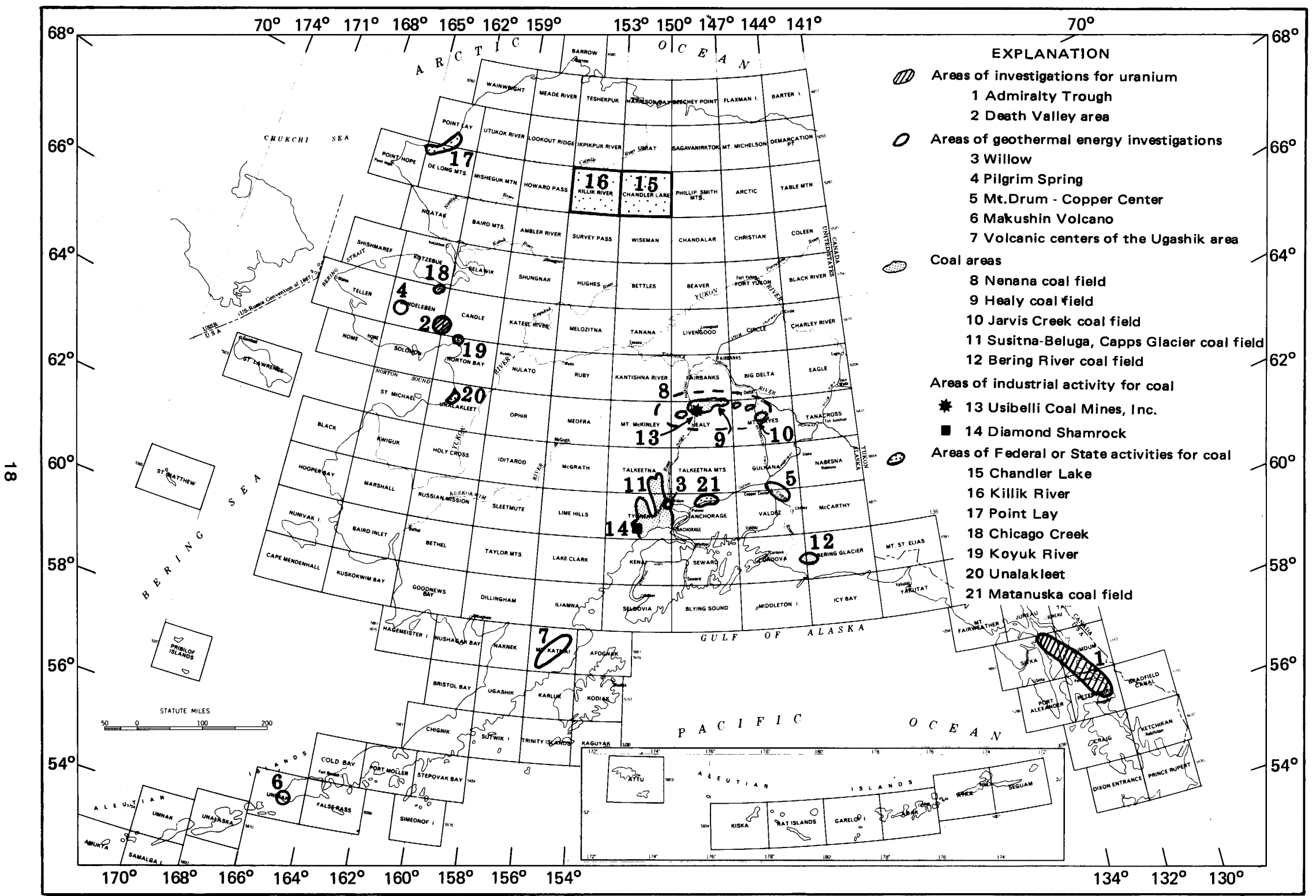

Figure 4.--Areas of Federal, State, and industry acitivity for coal, uranium, and geothermal energy resources. 
and Copper Center in the Wrangell Mountains (fig. 4 ), are scheduled for publication in 1984 .

A statewide compilation of geothermal resources was completed in 1983 by DGGS and the University of Alaska with funding from the Department of Energy. The resulting map is scheduled for release in 1984. Additionally, four regional geothermal-resource maps have been completed by DGGS for publication in 1984.

\section{COAL AND PEAT}

In 1983 , as in the previous years, the State of Alaska, the Department of the Interior, and industry continued to emphasize Alaska's coal potential as a present and future energy source. The geologic setting and locations of the major coal fields in Alaska were briefly described in U.S. Geological Survey Circular 884 (1982). Of the 10 medium to large coal fields in the State, four have been of particular interest to industry: (1) Beluga-Capps Glacier, (2) Nenana, (3) Bering River, and (4) Jarvis Creek (fig. 4). The northwest part of the Northern Alaska and the Matanuska coal fields (fig. 4) were also under investigation by the State.

Reported peat production in 1983 was about 15,000 cubic yards, the majority of this amount being used in greenhouse and agricultural projects in interior and western Alaska (Alaska Division of Geological and Geophysical Surveys, written commun., February 1984). No Federal or State agencies were active in commercial peat energy projects, and no records for domestic consumption of peat as fuel were made public in 1983.

\section{ACTIVITY BY FEDERAL AGENCIES IN 1983}

U.S. Geological Survey.-The Geological Survey has been investigating the southeastern part of the Northern Alaska coal field as part of the Alaska Mineral Resource Assessment Program, or AMRAP (more fully described in the section about nonfuel minerals). The Killik River and Chandler Lake $1: 250,000$-scale quadrangles (fig. 4) contain coal in their northern parts. The coal is exposed on the flanks of east-west-trending anticlines and synclines. Preliminary analyses of samples indicate that these coals have a low sulfur content, moderate amounts of ash, and an apparent rank of high-volatile $\mathrm{C}$ bituminous.

The Cook Inlet coal lands have been investigated by the Geological Survey for several years. This study has focused on the nature, location, and extent of geological characteristics important to engineering and design of roads and structures, as well as potential problems that could result from coal mining activities proposed for this area. Drilling operations, an important part of this investigation to determine the physical properties of the coal-bearing rocks and other geologic materials, have provided cores of the coal and associated rock for chemical and physical analyses (Odem and others, 1983, listed with Geological Survey references at the back of this circular).

Bureau of Land Management.-The Bureau of Land Management has issued a lease to a group of investors in Fairbanks for a coal deposit in the Jarvis Creek coal field (fig. 4). According to the Alaska Journal of Commerce and Pacific Rim Reporter (April 11, 1983), the proposed 2,560-acre surface mine is the first Alaskan coal deposit to be leased by the Bureau in 36 years. The project is discussed further under "Industry Activities."

\section{STATE ACTIVITIES IN 1983}

The State of Alaska has assumed primary responsibility for regulating the surface effects of coal mining within its borders. The Anchorage Daily News (March 17, 1983) reported that the State's program provides performance standards for surface coal mining and reclamation practices. The program also permits the State to develop a system to reclaim previously mined and unreclaimed land. The Department of Natural Resources, Division of Mining, contracted with PLANgraphics Inc. to develop a plan for implementing methods of mine reclamation. The contract was funded by the Federal Government, with a priority placed on reclamation of abandoned coal mine areas. The State is preparing to implement the completed plan. In another reclamation study for the State contracted to PLANgraphics, an environmental assessment and a plan for reclaiming an abandoned site near Houston, along the railroad north of Anchorage, were prepared; the Division of Mining planned to begin action in 1984. PLANgraphics has also produced a booklet, titled "An orientation to five Alaskan coal fields," that gives general descriptions of the environments of the Beluga, Bering River, Healy, Lisburne, and Matanuska coal fields. The booklet is available for inspection at the Division of fice at $\mathbf{5 5 5}$ Cordova Street in Anchorage.

The Division of Geological and Geophysical Survey (DGGS) has begun an investigation of the Matanuska coal field. The study is to focus on synthesizing all available data on this field, establishing a sampling program for coal quality investigations, and studying the geological history of the area.

DGGS has planned a coal exploration program in the northwestern part of the State. Petroleum Information's Alaska Report (July 6, 1983) notes that the State was evaluating proposals from private firms for drilling and geophysical work near Chicago Creek, Koyuk River, and Unalakleet (fig. 4). Work at Chicago Creek calls for 10 holes to a depth of 200 feet; at Unalakleet, 10 holes to about 150 feet; and at Koyuk River, 20 holes to 50 feet and one to 200 feet. 


\section{COOPERATIVE STATE-FEDERAL STUDIES IN 1983}

The Bureau of Land Management and the Alaska Department of Natural Resources have a cooperative agreement to study coal for local use in the western part of the Northern Alaska coal field (fig. 4). (See U.S. Geological Survey Circular 884, 1982.) The Alaska Journal of Commerce and Pacific Rim Reporter for November 14, 1983, and the Bureau report that a coal exploration drilling program, designed and supervised by the Bureau, was conducted in the Deadfall syncline area northeast of Cape Beaufort. Thirty-one holes were drilled using a helicopter-portable rotary drill with a compressed-air circulation system. Total drilled footage was approximately 4,400 feet, including about 90 feet of core in the thicker coals. The thickest coal without significant partings was about 18 feet thick. Preliminary estimates indicated strippable resources of about 20 million tons, of which about 8.5 million tons occurs in one bed over an area of nearly 330 acres. Resources that could be developed with conventional underground methods are considerably larger. Analyses of cores and drill cuttings are being made by the Mineral Industry Research Laboratory of the University of Alaska. Averaged analyses from cores from two holes in the thick bed described above indicate a heating value of $12,813 \mathrm{Btu}, 3.5$ percent moisture, 7.7 percent ash, and 0.24 percent sulfur, as received. Analyses of float fractions (1.5 specific gravity) indicate a heating value of $13,677 \mathrm{Btu}, 3.7$ percent ash, and 0.24 percent sulfur, representing 89 percent of the coal by weight. Moist, ash-free heating values are consistent between the two locations, which are about 3 miles apart along the strike of the bed. A cursory examination of analyses of cores and drill cuttings indicates comparable heating values for several other coals in the same stratigraphic interval, with a moderate reduction stratigraphically higher in the section. The uppermost coal sample has a moist ash-free heating value of $13,148 \mathrm{Btu}$ and is between 3,000 and 4,000 feet higher in the section than the thick bed referred to above. The overall coal rank for the basin appears to be in the high-volatile bituminous range.

\section{INDUSTRY ACTIVITIES IN 1983}

The following are highlights of the year's activities by private industry.

* A group of investors based in Fairbanks have been issued a lease to develop the Jarvis Creek coal field south of Delta Junction (fig. 4). According to the Alaska Economic Report of April 7, 1983, and the Bureau of Land Management, plans were being made to improve access and do additional drilling in summer 1984. The group proposes to supply coal to the Fort Greeley powerplant and to homes, farms, and businesses in and near Delta.
* An area in the Matanuska field (fig. 4) is under consideration for development by a combination of Hawley Properties, Inc., Sun Eel Shipping Corp. of South Korea, and, possibly, Daewoo, also of Korea. According to an article in the January 1984 issue of Alaska Construction and Oil, Rocky Mountain Energy, Inc., of Denver has taken an option to be the managing and operating partner in this venture. More than 30 holes were drilled in 1983, and bulk samples were tested. The coal has a Btu per pound range of 12,000 to 13,000 , and there are "substantial" reserves.

* Placer-Amex's Evan Jones coal mine, 15 miles east of Palmer in the Matanuska coal field, is on standby until there is a greater demand for coal. The mine, which was actively worked from the late 1950 s until 1968 , still has significant reserves of low sulfur coal.

* The Bering Development Corporation, a joint venture of the Chugach Natives, Inc., and four Korean partners, is continuing the investigation of the Bering River coal field (fig. 4). This coal is being sought as a source of domestic space heat in Korea. Petroleum Information's Alaska Report (Aug. 7, 1983) states that an agreement has been signed to do field mapping of 30,000 acres of the corporation's coal field. Coal rank ranges from lignite to anthracite. Uncertain reserves are estimated to range from 60 million to 3 billion short tons of coal. The partners hope to ship 5 million short tons per year to Korea. In addition, the City of Cordova has received a $\$ 500,000$ State grant for a port and transportation study so as to be prepared for possible coal development in the area. Not yet identified are the routes for moving the coal to tidewater and a port site.

* Beluga coal (field shown in fig. 4) can be competitive in both the U.S. West Coast and the Pacific Rim countries with exports of coal beginning as early as 1986, according to Petroleum Information's Alaska Report (Aug. 7, 1983). The article also noted that the Diamond Shamrock Corp., operator for the Diamond Chuitna Project, has finished the exploration and preliminary engineering phases and that the project was in the permit processing stage. Diamond Shamrock proposes a 12-mile-long conveyor system to carry coal from the surface mine to tidewater southwest of Tyonek and a 2-mile conveyor to move the coal to an offshore, deep water loading terminal. Initially, 5 million short tons of coal per year would have to be shipped for the operation to be profitable, and production could increase to 14 million short tons per year, according to the Alaska Journal of Commerce and Pacific Rim Reporter (July 25, 1983). Test samples of Beluga coal were 
shipped to potential users early in 1983 , but as of early 1984, no contracts had been announced (Alaska Construction and Oil, January 1984).

* Environmental Research and Technology Inc. has been awarded a contract for environmental studies on the Diamond Chuitna project in the Beluga coal field. The contract includes reclamation plans and an environmental protection study for a strip-and-backfill coal mine; annual production could be as high as 14 million short tons of coal, according to Petroleum Information's Alaska Report (Sept. 28, 1983).

* The joint-venture Beluga coal liquefaction plant, a proposal made by the Cook Inlet Region, Inc., and Placer-Amex, was rejected for Federal aid by the Synthetic Fuels Corporation in 1982. However, the partners in the proposed coal-to-methanol plant have been asked to resubmit their proposal to the corporation for approval.

* The Usibelli coal mine at Healy (Nenana coal field, fig. 4) is preparing to ship 800,000 metric tons of coal per year over the next 15 years to the Korean Electric Power Company, beginning in 1984. According to the Alaska Economic Report (Dec. 13, 1983), the future of this operation was strengthened when a State contract was signed for $\$ 3.8$ million of harbor dredging and dock construction at the ice-free port of Seward. Dredging is essentially finished. The export terminal is scheduled for completion in November 1984, the target date for the first shipment of coal. Sun Eel has also contracted for $\$ 20$ million worth of improvements at the Usibelli coal mine and $\$ 18$ million to $\$ 20$ million for 75 hopper cars, 5 locomotives, and a 100,000-ton ship. However, some critical financial arrangements were incomplete in early 1984.

* The Usibelli mine was awarded a $\$ 14,835,015$ contract from the Federal Government (Anchorage Times, July 13, 1983) to supply 417,300 short tons of coal to used for the Alaska Railroad, Fort Wainwright, Eielson Air Force Base, and Clear Air Force Station.

\section{REFERENCES CITED}

Alaska Construction and Oil, P. O. Box 101980, Anchorage, AK 99510.

Alaska Economic Report, published by Alaska Information Service, 3037 South Circle, Anchorage, AK 99507.

Alaska Journal of Commerce and Pacific Rim Reporter, 715 L Street, Anchorage, AK 99501.

Anchorage Daily News, 200 Potter Drive, Anchorage, AK 99502.

Anchorage Times, 840 West 4th Avenue, Anchorage, AK 99501.
Petroleum Information, Alaska Report, published by Petroleum Information, a subsidiary of $A$. C. Nielson, P. O. Box 102278, Anchorage, AK 99510.

\section{NONFUEL MINERALS}

Alaska's nonfuel mineral industry in 1983 reflected the weakness of the international metals market. Exploration expenditures for base metals diminished substantially, but spending increased for predevelopment work on properties at Greens Creek, Quartz Hill, and Red Dog. Thus, for the first time in the history of the State, according to reports in Mining Engineering (May 1983), expenditures for development in 1982 approached expenditures for exploration: development expenditures increased to about $\$ 42$ million, an increase of 68 percent over 1981 , and exploration expenditures decreased 41 percent to about $\$ 45$ million. Final figures are not yet available for 1983 activity, but apparently there were further cutbacks in exploration expenditures, and unpatented claims on many promising mineral occurrences received only the minimum required annual assessment work. Development expenditures, however, were at or near the 1982 levels. Exploration Drilling Incorporated, the minerals division of Placid Oil Company, and Houston International Minerals Company had severe cutbacks to, or reorganizations of, their Alaskan exploration efforts, and Gulf Minerals closed its six-person office in Anchorage. A dozen other large companies with exploration programs in Alaska continued at about their 1982 levels (Petroleum Information, Alaska Report, April 6,1983 ). (Unless otherwise indicated, references cited in this section appear on the last page of the section.)

Placer mining for precious metals continued to play a major role in the economy of Alaska, especially in the interior region of the State. Significantly, the number of large operations increased, and they became more efficient as miners improved their methods for recovering fine gold. In addition, several companies displayed renewed interest in 1983 in offshore gold placers in upper Cook Inlet, Norton Sound near Nome, Kotzebue Sound, and other tidewater areas of the State, including tailings placed in Gastineau Channel during processing of lode ores from Juneau gold mines. After a period of rapid growth in recent years, the placer mining industry is apparently levelling off, but the quest for new lode deposits of precious metals, as well as work on known deposits, has increased significantly (Sims, 1984). An article in the June 21 issue of the Anchorage Daily News indicates that 169,000 ounces of gold were produced by about 300 placer mines statewide.

Although the mood of those who attended the Fifth Annual Placer Mining Conference in Fairbanks in March 1983 was upbeat in anticipation of further 
increases in gold production, the impact of waterquality regulations is a growing concern. The effect of placer mining on streams was the subject of a symposium in Fairbanks in March 1983 sponsored by the Alaska Division of Geological and Geophysical Surveys. Operators of large placer mines and most small mines indicate that they cannot meet the settleable solids requirements of present waterquality standards and still make a profit. In April 1983, the Alaska Miners Association (AMA) formally requested that the Alaska Department of Environmental Conservation (DEC) either reclassify the Tolovana River and 17 tributaries in the Livengood and Tolovana districts, as well as Nolan Creek and 5 tributaries in the Wiseman district, to "industrial water quality" or develop a use category specifically for placer mining. In September 1983, the DEC granted the reclassification of Nolan Creek and tributaries but denied reclassification of the Tolovana River and tributaries. In January 1984, the DEC suspended efforts to reclassify other streams pending clarification of new Federal waterquality regulations.

The AMA was active in other endeavors in 1983. In July, the association sponsored its second annual mining tour that visited four mines in the Northwest Territories of the Canadian Arctic that faced developmental and operational constraints similar to those that will be faced by potential mines in Alaska. In October of 1983 the association reiterated its position that lack of transportation access is the greatest impediment to development of Alaskan mineral deposits and that, therefore, acquisition and expansion of the Alaska Railroad could become a key to the development of a hard-rock mining industry in the State. Also in October, the AMA sponsored its annual convention with the theme, "Alaskan minerals for Pacific Rim markets;" individua] sessions amplified the prospect that Asian countries such as Korea, Japan, and Taiwan could act not only as markets for Alaskan raw materials but could also be expected to supply joint-venture capital.

The number of new mining claims filed in 1983 on Federal and State lands continued to drop; the total $(10,728)$ was about 72 percent of the 14,958 claims filed in 1982. The dollar value of mineral production from existing properties, however, continued to increase, according to preliminary figures collected by the U.S. Bureau of Mines. An article in the Anchorage Daily News (June 21, 1983) notes that 1983 nonfuel mineral production was valued at about $\$ 232$ million; this is about 18 percent greater than the value reported in 1982 . The chief commodities contributing to this value were sand, gravel, and crushed stone for construction, and gold. Alaska also produced minor quantities of gemstones (coral, jade, and soapstone), silver, and placer tin concentrates. The average price received for sand and gravel increased about $\$ 0.84$ per ton above the 1982 price, but the price received for crushed stone decreased $\$ 0.68$ per ton. The average price received for gold increased from $\$ 376$ to $\$ 425$ per troy ounce. Alaska's nonfuel mineral production ranked 35th in the United States in 1983. A brief listing of volume and values for significant nonfuel minerals is given in table 3.

The political climate in Alaska swung steadily toward policies that may aid the development of new mineral deposits. Four specific actions may be

Table 3.-- Mineral production in Alaska, 1982-83

(from the Alaska Division of Geological and Geophysical Surveys staff, written commun., February 1984)

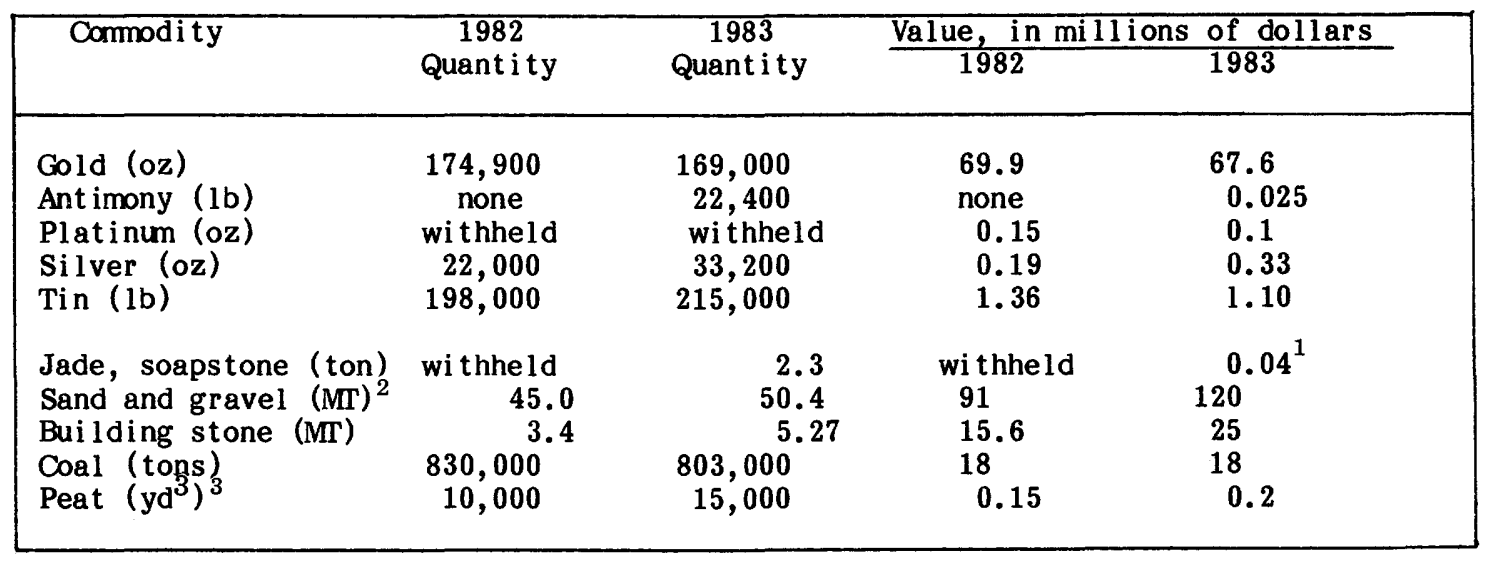

1 Does not include jade from Northern Alaska Native Association's Kobuk operation

$2 \mathrm{MT}=$ million short tons

3 Agricultural uses 
selected as symptomatic. (1) In August 1983, the Alaska legislature passed Senate Bill (SB) 151, which permits the creation of regional authorities with the power to issue revenue bonds to finance infrastructure costs. This legislation may have an immediate favorable influence on the pending decision whether to proceed with development of the Red Dog and adjacent properties in northwestern Alaska. (Of the anticipated $\$ 370$ million to bring Red Dog into production, 54 percent is in infrastructure costs, including a 60 -mile haul road to the coast and a port storage and loading facility.) Ultimately, SB 151 may influence the development of other remote properties in areas such as the Ambler district, where transportation access is lacking. (2) In October 1983, Governor Sheffield, by executive order, created a Division of Mining within the Department of Natural Resources, thereby fulfilling a campaign pledge to "give the mining industry high-level attention"; in addition, the Sheffield administration issued a memorandum of intent to reduce permit processing time and to initiate other regulatory reforms to aid miners. (3) In December 1983, the Alaska Land Use Council and the U.S. Forest Service approved an exchange of land that will recommend the removal of the Greens Creek mineral claims from Admiralty Island National Monument, thereby permitting the operator more time to complete feasibility studies prior to development of the claims. (ANILCA requires "prove-up" on claims in the monument by 1985.) Other similarly motivated land exchanges elsewhere in Alaska are being proposed; some are predicated on rulings that may create transportation or utility access routes across National Interest Lands -rulings that were being formulated for release in spring 1984. (4) In January 1984, the Alaska Department of Natural Resources announced that it is expediting decisions on a backlog of approximately 850 permit requests for offshore mineral exploration in anticipation of a June 30,1984, reopening of exploration and leasing program. This program, applicable to all State-owned tidal and submerged lands, has been closed since 1975 .

\section{ACTIVITY BY FEDERAL AGENCIES IN 1983}

U.S. Geological Survey.-The statewide Alaska Mineral Resource Assessment Program (AMRAP) continued at approximately the same level of activity as in 1982. The Roadless Area Resource Evaluation (RARE II) and Wilderness Study program in the Prince William Sound-Kenai Peninsula area and work funded by the Office of National Petroleum Reserve in Alaska (ONPRA) in northwestern Alaska are nearing completion. Locations of areas studied are depicted on figure 5 , and table 4 lists the projects that are included.

AMRAP functions at four levels of progressively greater detail to produce comprehensive assessments of Alaska's mineral and energy endowment. In Level I, which is statewide at a scale of
$1: 2,500,000$, summaries of occurrences of specific commodities were updated. In Level II, which is regional at a scale of 1:1,000,000, a single project to evaluate and to synthesize existing information on the mineral resources of southeastern Alaska is nearing completion. In Level III of AMRAP, which is the present main thrust of the program, multidisciplinary evaluations of the characteristics and abundances of resource oćcurrences are under way for eighteen 1:250,000-scale quadrangles that are judged to have significant potential. These include quadrangles in the western and north-central Brooks Range, the Seward Peninsula, western interior Alaska, the eastern Alaska Range, the Alaska Peninsula, and southeastern Alaska. EROS Data Center personnel are supporting Level III projects

Table 4.- Abbreviated titles or brief descriptions of projects whose study areas are shown in figure 5

\begin{tabular}{|c|c|}
\hline $\begin{array}{l}\text { Project identi- } \\
\text { f ication number }\end{array}$ & Project name \\
\hline 1 & $\begin{array}{l}\text { Southeastern Alaska } \\
\text { geotectonics and } \\
\text { metallogenes is }\end{array}$ \\
\hline 2 & $\begin{array}{l}\text { Juneau and Taku River } \\
\text { quadrangles }\end{array}$ \\
\hline 3 & $\begin{array}{l}\text { Port Moller and Stepovak } \\
\text { Bay quadrangles }\end{array}$ \\
\hline 4 & $\begin{array}{l}\text { Mount Katmai and Naknek } \\
\text { quadrangles }\end{array}$ \\
\hline 5 & Chugach RARE II study \\
\hline 6 & Anchorage quadrangle \\
\hline 7 & $\begin{array}{l}\text { Alaska accreted igneous } \\
\text { ares }\end{array}$ \\
\hline 8 & Healy quadrangle \\
\hline 9 & $\begin{array}{l}\text { Eastern Alaska Range } \\
\text { metallogenes is }\end{array}$ \\
\hline 10 & Yukon-Tanana Uplands \\
\hline 11 & Ruby and Ophir quadrangles \\
\hline 12 & $\begin{array}{l}\text { Unalakleet and Norton Bay } \\
\text { quadrangles }\end{array}$ \\
\hline 13 & $\begin{array}{l}\text { Álaska mafic and ultra- } \\
\text { mafic rocks }\end{array}$ \\
\hline 14 & $\begin{array}{l}\text { Alaska gold placers; } \\
\text { Circle district tin \& } \\
\text { tungsten }\end{array}$ \\
\hline 15 & $\begin{array}{l}\text { Alaska tectonostrati- } \\
\text { graphic terranes }\end{array}$ \\
\hline 16 & $\begin{array}{l}\text { Solomon and Bendeleben } \\
\text { quadrangles }\end{array}$ \\
\hline 17 & Yukon-Koyukuk transect \\
\hline 18 & Baird Mountains quadrangle \\
\hline 19 & Wi seman quadrangle \\
\hline 20 & $\begin{array}{l}\text { Killik River and Chandler } \\
\text { Lake quadrangles }\end{array}$ \\
\hline 21 & $\begin{array}{l}\text { Al aska pal eomagnetic } \\
\text { studies }\end{array}$ \\
\hline
\end{tabular}




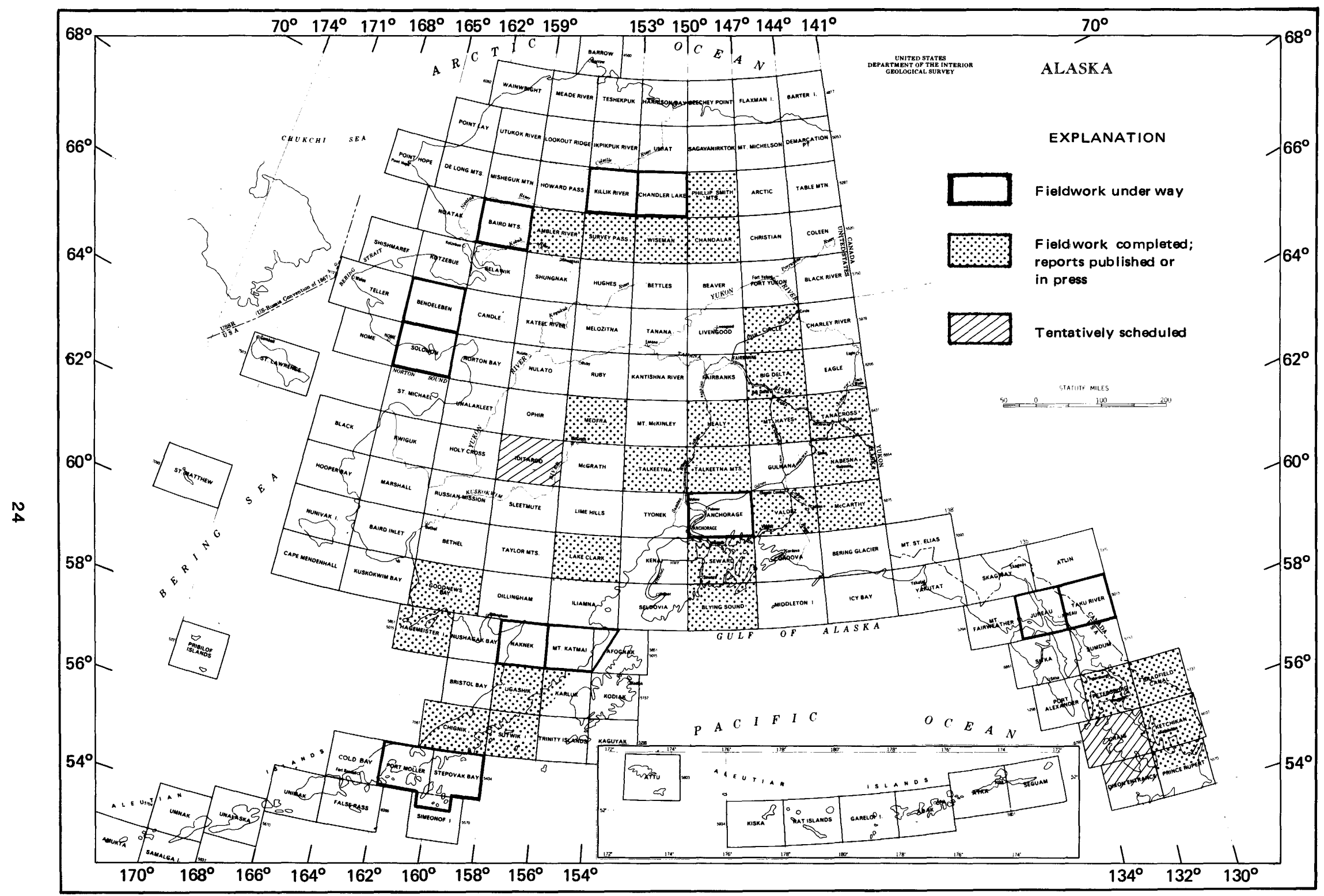

Figure 5.--Locations of areas studied by the U.S. Geological Survey and the Bureau of Mines for nonfuel, critical, and strategic minerals. See table 4 for titles or brief descriptions of projects. 
on (1) the Seward Peninsula in order to provide computer analysis of geochemical, geophysical, and geologic data, and (2) the Alaska Peninsula, where multispectral scanner data are being specially processed to aid in the interpretation of surface mineral alteration. An AMRAP project was initiated in the Baird Mountains quadrangle of the western Brooks Range. Figure 6 shows the current status of AMRAP Level III studies. Level IV consists of detailed studies at a scale of $1: 63,360$ or larger of mineral districts, specific deposits, or topies related to the formation of deposits; 44 continuing projects are scattered throughout the State. They include studies of the base metal deposits of the Noatak and Ambler districts of the western Brooks Range, base and precious metal deposits of the Delta district of the eastern Alaska Range, and precious metal, tin, and tungsten deposits of the Circle district in the eastern interior of the State. Many Level III and IV studies are made in cooperation with scientists from other Federal, State, or Canadian agencies and from educational institutions. More than 70 publications resulted from these Level III and IV studies; many are listed among selected references in the back of this circular.

In 1982 fieldwork was completed by the Geological Survey and the Bureau of Mines on a joint RARE II and Wilderness Study project that encompasses more than 5.6 million acres in the Chugach National Forest of southern Alaska. A joint Geological Survey-Bureau of Mines synopsis of the mineral resource potential within this National Forest was published in early 1984 (Nelson and Jansons, 1984). A mineral and energy resources assessment at a scale of 1:250,000 for this region will be completed in 1984 .

Field studies by the ONPRA in the western Brooks Range, with Geological Survey and Bureau of Mines participation, have been concluded. $\mathrm{Nu}$ merous reports have been issued since 1978 about the NPRA and contiguous areas.

Bureau of Mines.-Accomplishments of the major Bureau programs in Alaska are summarized below. Four programs of the Bureau of Mines provide information about the nonfuel mineral potential of Alaska: (1) Mineral Land Assessment Program; (2) Mineral Availability Program; (3) Policy Analysis Program; and (4) State Mineral Specialist. The Bureau's work on critical and strategic minerals is presented in a section with that title.

Mineral Land Assessment-Mineral land assessments that provide evaluations of specific mineral occurrences were completed in four areas in 1983: (1) Chugach National Forest (with the Geological Survey, for the Forest Service); (2) the IditarodGeorge Planning Block in western Alaska (for the Bureau of Land Management); (3) the Kantishna Hills and the Dunkle Mine areas (with the Alaska Division of Geological and Geophysical Surveys (DGGS), for the Alaska Land Use Council); and (4) various regional critical and strategic mineral studies in Alaska, which are discussed further in the section titled "Critical and Strategic Minerals." These projects are briefly described in the paragraphs that follow.

The Chugach National Forest study was part of a RARE II program. Fieldwork was completed in 1982, and several Bureau and joint Bureau-Geological Survey reports were in progress in 1983. Preliminary reports summarizing detailed Bureau investigations of gold, molybdenum, copper, and manganese occurrences were published in 1982 and 1983 (Haney, 1982; Jansons and others, 1983; see also Nelson and Jansons, 1984).

The Kantishna Hills and Dunkle Mine study area as defined by ANILCA were evaluated through four studies involving Bureau staff and contractors. A mineral resource study contracted to Salisbury and Dietz, Inc., of Spokane, Wash., identified geologic environments permissive for large stratiform base and precious metal mineralization, located 17 new mineral occurrences, estimated a reserve of 688,000 ounces of placer gold in 43 million cubic yards of gravel in the Kantishna Hills, and identified a geologic environment permissive for breccia pipe deposits containing gold and porphyry-type deposits containing copper and molybdenum in the Dunkle Mine area. Mining feasibility studies performed by the Bureau suggest that precious metal and antimony veins may be currently economic to mine in the Kantishna Hills area. Regional mineral endowment assessments made by the DGGS under contract to the Bureau suggest the probability of recovering from $\$ 375$ million to $\$ 7.2$ billion worth of minerals at the 95 percent and 5 percent confidence levels, respectively, from the two study areas. Fieldwork included regional and detailed geological mapping, diamond core drilling at some lode mines and prospects for geological information, chemical and geophysical surveys, and placer sampling. For estimating the cost of mineral claim acquisition, the mineral estate was considered for both patented and unpatented claims. The additional value of the surface estate was determined for patented claims. DOWL Engineers/PLANgraphics of Anchorage, under contract to the Bureau, estimated the cost of acquiring mining claims in the two areas might be as much as $\$ 157,208,000$. The studies have aided the Alaska Land Use Council in formulating recommendations to Congress regarding management of these two areas.

In 1983, the Bureau conducted a literature search that was followed by a 10-day field visit in the Iditarod-George Planning Block for the Bureau of Land Management. Previous data and analytical results of 1983 samples were used to identify mineralized and areas with potential for mineralization.

Mineral Availability Program-This program provides a system summarizes, stores, and updates information about mineral deposits statewide. 


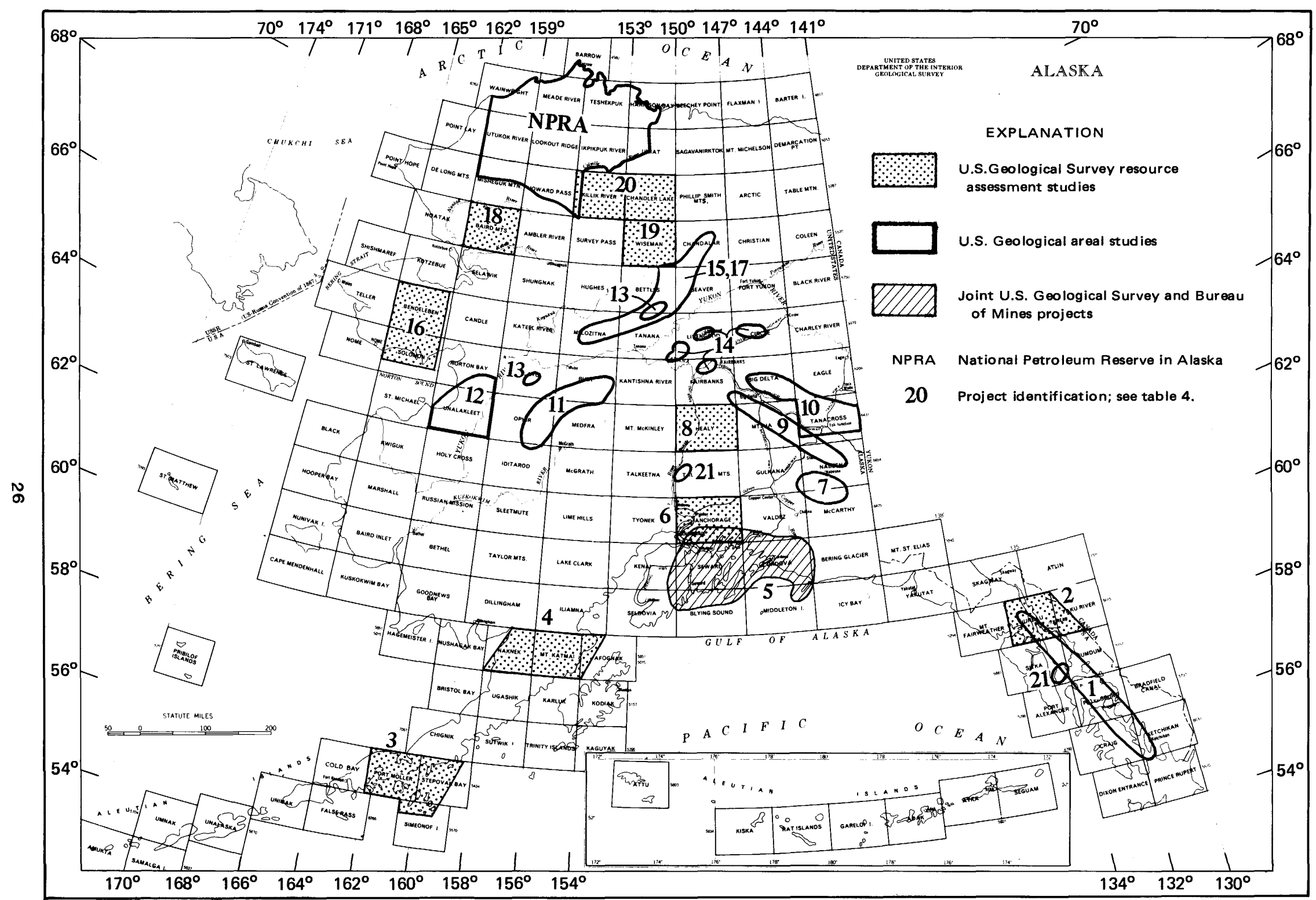

Figure 6.--Status of Level III Alaska Mineral Resource Assessment Program studies, January 1, 1984. 
Three hundred and forty-eight Alaskan properties were entered in the MILS data base in 1983 as potential mineral producers.

In 1983, complete MAS deposit evaluations were carried out on eight Alaskan mineral properties. The evaluations assess the quantity and quality of commodity present, mining and beneficiation technologies, capital and operating costs, and institutional constraints.

Information about MAS or MILS products, such as data printouts or computer-plotted overlays, can be obtained from the Chief, Alaska Field Operations Center, Juneau, Alaska.

Policy Analysis Program-The policy analysis program evaluates newly developed and existing mineral data to interpret its significance relative to national needs. Studies in progress or recently completed include: (1) listing of all known chromite, cobalt, and platinum-group metal occurrences in Alaska and estimating the feasibility of mining them; and (2) putting into a computerized format sample points and analytical results from Bureau of Mines field projects in the Glacier Bay, Granite Fiords, Tracy Arm-Fords Terror areas of southeastern Alaska; these will be available for future reinterpretation.

State Mineral Specialist--Under this program, the Bureau provides coverage of mineral activities in Alaska and the development and release of nonfuel minerals industry data for the State.

Reports prepared in 1983 include the section covering Alaska for the "Minerals Yearbook"; a section for Alaska's "Minerals and Materials," a bimonthly survey; reports on foreign investments in domestic minerals; and briefing summaries for visiting executives and representatives. The Bureau provided information for the preliminary draft of the environmental impact statement (EIS)" Quartz Hill Molybdenum Project Mine Development." A list of bills of interest to the minerals industry that were being considered by the current session of the Alaska legislature was also prepared.

In February 1983, the Bureau sponsored, in Anchorage, an International Conference on Coal, Minerals, and Petroleum, at which W. P. Pendley, former Assistant Secretary for Energy and Minerals in the Department of the Interior, and R. C. Horton, Director of the Bureau of Mines, gave their perspectives on the potential for development of Alaska's resources.

Bureau of Land Management.-The Bureau issued eight mineral patents in 1983 , including one to Pacific Coast Molybdenum Co. for 32 lode claims in the Misty Fiords area near Ketchikan. The Kennecott Corporation received patents for two lode claims adjoining a group of patented claims in the Ambler district. Seventeen gold placer claims were patented to six other individuals or groups.

In November 1983, in conformance with Section 1008 of ANILCA, the Bureau opened 5.7 million acres of Federal lands in the Seward Peninsula area for staking locatable minerals claims under Public Land Order 6477. The opening includes scattered tracts near Selawik, in the Nulato Hills, along the Squirrel and Noatak Rivers, as well as areas on the peninsula. The Seward Peninsula area is considered to be one of the Nation's best remaining frontier areas for the discovery of metallic mineral deposits.

The Bureau of Land Management and the Bureau of Mines cooperated in a reconnaissance survey of the Iditarod-George Planning Block, an area encompassing about 4 million acres of western Alaska. The Bureau of Land Management used geochemical sampling techniques to test for the presence of 31 elements in 172 stream-sediment samples collected as part of the search for mineral deposits. The Bureau of Mines completed a literature search and carried on limited field studies to enhance the data base for the area. A report of the results of this joint effort details areas of geochemical anomalies, known mines, prospects, and mineral occurrences, and it recommends areas for further work. Copies of the report are available for review at the District Office of the Bureau of Land Management. The Bureau of Mines plans a formal publication about this work.

U.S. Forest Service.-The Forest Service granted permission for construction of a 5-mile access road to five placer gold mining claims on Crescent Creek on the Kenai Peninsula in the Chugach Forest. The road has been completed and used during testing of these claims.

One of the large mining developments in southeastern Alaska, Greens Creek, is in the Tongass National Forest. Noranda Mining, Inc., has requested a Forest boundary adjustment to facilitate exploration of the ore body and thus minimize environmental impacts. The Forest Service is currently reviewing this proposal. Further details are given under the heading "Industry Activity in 1983" in this section.

The U.S. Borax and Chemical Company's Quartz Hill molybdenum deposit is in the Misty Fiords National Monument, on claims in a 152,000-acre tract that does not have wilderness classification. The access road was completed in 1983 and has been used to transport bulk samples. An EIS is being prepared, with the Forest Service as lead agency, to consider the remainder of mine development plans. More information about this project is given under "Industry Activity in 1983", this section.

U.S. Fish and Wildlife Service.-In keeping with the Service's primary mission, major efforts relating to mineral activities in Alaska have emphasized fish, wildlife, and habitat protection. However, about 1,200 mining claims, located before the passage of ANILCA, are recorded on 13 of Alaska's National Wildlife Refuges (NWR). The claims are tabulated below. An additional $\mathbf{4 2 5}$ millsite claims are on NWRs; nearly all of these claims are near Cape Seppings in the Cape Thompson unit of the Alaska Maritime NWR. Mineral survey applications 
are on file for 96 lode and placer claims in the Togiak NWR near Goodnews and for 7 lode claims withheld from Native conveyance on Unga Island near the Apollo gold mine.

\begin{tabular}{|lcc|}
\hline $\begin{array}{c}\text { National Wildlife } \\
\text { Ref uge }\end{array}$ & $\begin{array}{l}\text { Lode } \\
\text { claims }\end{array}$ & $\begin{array}{c}\text { Placer } \\
\text { claims }\end{array}$ \\
\hline Alaska Maritime & 21 & 3 \\
Alaska Peninsula & 114 & 2 \\
Arctic & 88 & 7 \\
Becharof & -- & 1 \\
Innoko & 2 & -- \\
Kenai & -- & 24 \\
Koyukuk & 142 & -- \\
Nowi tna & -- & 4 \\
Selawik & 7 & -- \\
Tet lin & -- & 4 \\
Togiak & 182 & 155 \\
Yukon Del ta & 3 & 66 \\
Yukon Flats & 359 & 36 \\
Totals & 918 & 302 \\
\hline
\end{tabular}

In August, the Service issued the Bristol Bay Cooperative Management Plan and Draft EIS, as required by Section 1203 of ANILCA. The plan recommends closure of nearly 7,000 miles of streams to any new (placer) mining activity. Existing claims, depending upon the type of operation, generally will be allowed to continue.

The Fish and Wildlife Service was a cooperator with the U.S. Forest Service in the development of the EIS about the Quartz Hill mine access road and bulk sampling plan and in the mine development plan. The Fish and Wildlife Service provided technical assistance in the form of instream flow studies on Wilson River and Tunnel Creek in support of the water-supply plan for this mine. The Fish and Wildlife Service also assisted the Forest Service with Noranda's plans for mining at the Greens Creek deposit.

The proposed road from the Red Dog deposit to tidewater will cross the National Park Service's Cape Kruzenstern National Monument. This planned road requires an EIS to be prepared jointly by the Envionmental Protect Agency and the Department of the Interior. The Fish and Wildlife Service was a cooperator in this project.

The Fish and Wildlife Service assisted the Park Service with analysis of surface water for heavy metals and studies of fish in the streams in the Kantishna Hills and Dunkle Mine areas of Denali National Park and Preserve.

The Fish and Wildlife Service also provided significant review comments to the Bureau of Land Management regarding resource management plans for the White Mountains-Nation River Recreation Area and Steese Conservation Area. Similarly, comments were provided to the Alaska Department of Environmental Conservation for their plan to reclassify river systems under the Clean Water Act and to the Corps of Engineers and the Bureau of Land Management concerning a major placer mining operation on the Tuluksak River adjacent to the Yukon Delta NWR.

National Park Service.-The Service's activities related to nonfuel minerals are generally described in the paragraphs above. The Park Service cooperated in studies and EISs in the Denali National Park and Preserve and in the Cape Kruzenstern National Monument where proposed mining activity will impact Service lands.

\section{STATE ACTIVITIES IN 1983}

In March 1983, the Office of Mineral Development released a study, "The role of placer mining in the Alaska economy" (Berger and Associates, 1983), analyzing the history, characteristics, past production, present economic impact, and future potential of the placer mining industry. The study concluded that placer mining contributes substantially to the economy of Fairbanks, Nome, and several smaller communities, with estimated 1982 production of $\$ 70$ million, expenditures of $\$ 80-83$ million, and direct employment of nearly 2,400 people. The number of placer mines may be well over 500; at least 338 of these are mechanized. The report estimates that the remaining productive life of present mines averages about 14 years.

Also in March, the Mineral Industries Research Laboratory of the University of Alaska, Fairbanks, released abstracts and selected papers from the Fourth Annual Conference on Alaska Placer Mining as Report 61. Topies included descriptions of new deposits, exploration and operational methodologies, economics and productivity enhancement, reclamation, and regulations.

Throughout the year, the DGGS continued its release of claim status maps, for a total of 27 $1: 250,000$-scale quadrangles to date.

In May 1983, the DGGS and the Office of Mineral Development released Special Report 31, "Alaska's mineral industry, 1982," which summarizes the exploration, development, production, and drilling activities of the hardrock and energy mineral industries statewide (Eakins and others, 1983). The report covering 1983 was in press in June 1984.

Also in May, the DGGS released a report of its mineral resource appraisal of the Kantishna Hills and Dunkle Mine mining areas in Denali National Park and Preserve (Bundtzen, 1983) as one part of the joint State-Federal studies mandated by the Alaska Land Use Council through Section $2023 \mathrm{~b}$ of ANILCA. The Alaska Land Use Council was scheduled to present a recommendation for use of these areas in May 1984.

In June 1983, the Department of Natural Resources asked for public comments on its review of 
policy options for 12.5 million acres of State lands in the Tanana River basin. One alternative makes the development of minerals a priority.

In August the Department of Commerce and Economic Development released a report, "A Delphi forecast of Alaska's development-The year 2000 and beyond," that summarized the results of a poll of 91 distinguished Alaskans, including former governors, legislators, educators, and business leaders. The report reviewed factors encouraging and discouraging economic growth in the State according to the perceptions of those polled. The majority felt that land and resource development was one of the three most important issues facing Alaska, and most felt that the lack of transportation and access corridors is the most significant land issue.

In October, the Department of Natural Resources released its locatable minerals management study (Alaska Department of Natural Resources, 1983), which stated that although Alaska's hardrock mineral potential is virtually untapped, the mining industry has the highest growth potential of any Alaskan industry. The report evaluated various policy options the State might implement to encourage hardrock mineral development in several broad categories: (1) markets; (2) access and infrastructure; (3) fiscal policies (taxes, royalties, loans); (4) resource management (land availability, data collection, technical assistance); (5) regulation and permitting; (6) labor; and (7) organizational structure. In October Governor Sheffield indicated his choices in several of the policy options. By executive order, he reorganized the existing Division of Mineral and Energy Management into two new divisions, Oil and Gas (through reshuf fling of present programs) and Minerals (to be implemented in spring 1984). The governor also issued policy papers indicating his intentions to support regulatory reforms and subsidies for mining ventures. He pledged support for the regional development authorities established by the State legislature in 1983 and indicated that additional options were under consideration, such as State-financed roads or shipping facilities, outright grants, and tax-exempt bonds sold through the Alaska Industrial Development Authority.

In January 1984, the Division of Mineral and Energy Management announced its intention to reopen its noncompetitive offshore mineral exploration and leasing program for all State-owned tidal and submerged lands on June 30, 1984. The Anchorage Daily News (March 20, 1983) reported that there are only eight valid of fshore mining leases and 42 offshore prospecting permits in the State; however, permit holders are seeking to convert more than half of their present permits to leases, and $\mathbf{8 0 0}$ permits are pending in several areas of the State.

\section{INDUSTRY ACTIVITY IN 1983}

Three potentially important mineral properties in Alaska moved closer to major development decisions and were in the news and economic reports repeatedly during 1983 . The following paragraphs update information that appeared in Circular 908 (U.S. Geological Survey, 1983) about Greens Creek, Quartz Hill, and Red Dog.

Greens Creek-Greens Creek, near Juneau on the north end of Admiralty Island, is poised to become the first major hardrock metal mine to reach production in Alaska in the 1980s. Silver, gold, zinc, lead, and copper will be mined from a rich ore body by underground methods. Revised reserve estimates were issued in 1983 (California Mining Journal, 1983) and include 3.5 million tons of ore at 10 percent combined zinc, lead, and copper, with precious metal values of 12 ounces/ton silver and 0.16 ounces/ton gold. The projected life of the mine is at least 15 years. The precious metal values probably are the chief reason that development of the property still is nearly on schedule, the key being stability in the price of silver.

Noranda Mining, Inc., is the managing partner of the joint venture. Other partners are Anaconda Minerals Co., Texas Gas Exploration (a subsidiary of Mitsubishi), Bristol Bay Resources Inc. (of Bristol Bay Native Corporation), and Exalas Resource Corporation. Anaconda's purchase of the 33.8 percent interest formerly owned by Marietta Resources International was announced in April 1983 (Petroleum Information, Alaska Report, April 13, 1983).

The Greens Creek Final EIS and the Record of Decision by the U.S. Forest Service for the proposed project were completed and released in January 1983. U.S. Forest Service mineral examinations confirmed the validity of eight of the core claims. Validity of other claims has not been determined, although several additional promising mineral occurrences or extensions appear to be present. Section 504 of ANILCA specifies that claims must be perfected and be declared valid by December 2, 1985. Noranda increased its drilling on some of its unperfected claims in 1983 . The company believes that it may be impossible to obtain all necessary information by surface drilling within the time constraint. In a letter to the U.S. Forest Service dated June 2, 1983, Noranda requested relief from the provisions of Section 504 through adjustments of the boundaries of Admiralty Island National Monument. This would remove the unperfected claims from the time restraint and would allow greater opportunity to prove validity of unperfected claims through underground exploration techniques, thereby eliminating most environmental degradation that would result from surface drilling and trenching. The draft EIS for the proposed boundary change was released in early December 1983 for review and comment. It considers six alternatives, 
including no action. The alternative tentatively approved by the U.S. Forest Service and the Alaska Land Use Council proposes to move the northern boundary of the monument to exclude 17,225 acres of non-wilderness monument land, including the Greens Creek project area, and to add the Young Lake area of 18,174 acres to the monument. Road and site surveys and evaluations continued in 1983, and Noranda announced plans to begin constructing a road in 1984. The road will connect Young Bay to the proposed main shipping point near the cannery on Hawk Inlet, cross a ridge to Greens Creek canyon, and continue upstream to the mill site and mine.

Quartz Hill.-The Quartz Hill project continued to make progress toward production in 1988 and was the subject of numerous reports and articles in 1983 (for example, the May 9, 1983, issue of the Alaska Journal of Commerce and Pacific Rim Reporter, and the October issue of Western Miner). U.S. Borax and Chemical Corporation received patents to 32 lode mining claims in the Quartz Hill area on September 15, 1983. The 10-mile mine access road from Wilson Arm to the mine site was completed at an estimated cost of $\$ 14$ million and opened on August 12, 1983. Underground bulk sampling started earlier in the year, after completion of an EIS, and a 5,000-ton sample was trucked to the beach and shipped by barge and rail to the Hanna Mining Research Center at Nashawauk, Minn. Test work on the sample will involve crushing, grinding, and flotation processing. A concentrate will be produced in a test plant that would simulate a commercial plant operation. The testing program also will define and optimize design of various components of the treatment plant and tailings disposal facilities. Environmental studies and baseline data gathering are continuing. Bechtel Civil Engineering and Minerals, Inc., evaluated possible sites for the crushing plant, concentrator, powerplant, and other facilities. Preliminary plans were developed that envision a crushing plant near the east edge of the ore deposit, a mill and powerplant in Tunnel Creek canyon, and delivery of crushed ore by conveyor through a decline tunnel to the mill. Electrical braking on the conveyor system will generate part of the power for the operation. Tailings will flow by gravity through another decline tunnel from the mill for submarine disposal in Boca de Quadra fiord, although a new lawsuit challenging Forest Service approvals of the plans was filed in December 1983.

U.S. Borax announced a decision to house workers in Ketchikan instead of developing a townsite near the operating area in Misty Fiords National Monument. An EIS is being prepared by Envirosphere Company of Bellevue, Wash., for the Forest Service about the mine construction and operation; it is scheduled for completion about mid1984. The company then can decide on plant capacity and construction scheduling after receiving final approval by the U.S. Forest Service.
A permit has been requested from the Corps of Engineers for construction of a proposed $\$ 50$ million facility at the company's Grays Harbor site near Hoquiam, Wash.; this facility would consist of a roasting plant (to convert molybdenite concentrates to merchantable molybdenum oxide and 45,000 tons of sulfuric acid each year) and a transshipment facility (Petroleum Information, Alaska Report, Sept. 14, 1983). The latter will provide a modular preassembly and fabrication yard with a barge slip for loading and a staging area for collecting and transshipping construction equipment, materials, and operating supplies to the Quartz Hill mine.

Market conditions and the forecasts for molybdenum prices in the coming years are increasingly important in forecasting the feasibility and timing of development. The projected production start-up of 1988 and the initial proposed production rate are heavily dependent on both continued recovery of molybdenum prices from recently very depressed levels and an increased demand. The reserves of $\mathbf{1 . 5}$ billion tons of ore at a grade of 0.14 percent molybdenite, including 300 million tons at the surface grading better than 0.2 percent, indicate that the mine, once production is under way, will produce for many decades. However, the company (with $\$ 100$ million invested already; Southeastern Log, September 1983) must be able to recover the heavy initial developmental costs, which are anticipated to reach $\$ 1$ billion (in 1982 dollars).

Red Dog.-A project that figured prominently in the news in 1983 is Red Dog in northwestern Alaska, a zinc-lead-silver property to be developed under terms of an agreement between Cominco Alaska, Inc., and the Northern Alaska Native Association (NANA) regional corporation. The property was the subject of articles in the Anchorage Times in February 1983 and in the Northern Miner in April (Duval, 1983) and August (Tikkanen, 1983); it also was featured in presentations at the Alaska Miners Association Annual Meeting in Anchorage in October (Plahuta and others, 1983) and the Northwest Mining Association Annual Meeting in Spokane in December, where activities were described by a company representative.

Officers of the Canadian parent company claim that the development of Red Dog and nearby properties could influence the world zinc and lead mining industry for several decades, with significance perhaps as great as that of the Sullivan Mine in British Columbia (Northern Miner, Aug. 8, 1983).

Cominco Alaska, Inc., continued exploratory drilling at a reduced scale in 1983. Drilling at the Hilltop deposit, about a half mile south of the main deposit, has outlined significant additional reserves of fine-grained massive sulfide ore. This deposit is reported to be about 95 feet thick, dips to the south, and has metal values similar to those of the main Red Dog deposit. A 4-ton bulk sample for milling tests was obtained from the main deposit by 
drilling several 4-inch core holes through the ore zone. The ore minerals are very fine grained and are disseminated in a gangue of siliceous minerals and barite; iron sulfides and minor amounts of fluorite and other metallic minerals are also present. Conditions for open-pit mining are very favorable; the overall stripping ratio is only $1: 1$. Milling will require very fine grinding and precise metallurgical controls to produce clean, high-grade concentrates with good recovery of zinc, lead, and silver values. The collection of environmental data continues, as do designs for the mine, mill, tailings disposal, and transportation routes and studies of project feasibility. The Environmental Protection Agency is responsible for preparing the EIS for the proposed operation; the EIS is scheduled for 1984 completion. Permitting activities are continuing.

Cominco drilled additional exploration holes on its Su claims several miles west of Red Dog near the Wulik River and on other claim groups 12 miles to the northeast in 1983.

Legislation to permit creation of regional transportation authorities (SB 151) became State law in 1983. Regional authorities will have the power to issue revenue bonds to a total of $\$ 400$ million. Transportation facilities for the Red Dog project might cost as much as $\$ 200$ million, or more than half of total development costs.

On March 12, 1984, NANA and the Department of the Interior agreed to a land trade that will give the Native corporation the access route that it requires to get material from the Red Dog to tidewater. For the transfer of about 95,000 acres in the northern part of the Cape Kruzenstern National Monument to the corporation, NANA will cede about 103,000 acres to be added to the northeast section of the monument.

Red Dog could be a profitable venture for NANA. In May 1983 NANA received final rights from the Bureau of Land Management to 22,176 acres encompassing the Red Dog deposit. Production royalties for leasing the site on Native lands are $\$ 1$ million per year. During initial production, NANA will receive a percentage of net smelter returns or $\$ 1$ million per year, whichever is less, until payback. After payback, NANA will receive 25 percent of net proceeds, which will increase by 5 percent per year until the maximum, 50 percent per year, is reached.

\section{OTHER INDUSTRY ACTIVITIES IN BASE METALS IN 1983}

Locations for the items described below are shown on figure 7 and listed on table 5.

GCO Minerals, Inc., and Houston International Minerals Co. (HIMCO) did exploration drilling on their Lik group and other zinc-lead-silver claims in the Wulik River area west of Red Dog. Bear Creek Mining Co. (BCMC, a subsidiary of SOHIO) continued some exploration activities on claims in the same general area.
BCMC continued a scaled-back exploration program on their Arctic Camp copper-zinc deposit and other prospects in the Ambler district. Published data for the Arctic Camp deposit show that reserves exceed 40 million tons at 4 percent copper, 5.5 percent zinc, 1 percent lead, 1.6 ounces/ton silver, and 0.02 ounces/ton gold. Anaconda Minerals Co. (a subsidiary of Atlantic Richfield Co.) and Sunshine Mining Co. conducted limited exploration activities on their claim groups in the Ambler area and other claim groups in the Ambler River and Survey Pass quadrangles. Other companies active along the south flank of the Brooks Range were Noranda, $\mathrm{GCO}$, and Cominco.

Anaconda continued to drill at its recently discovered copper-silver-gold massive sulfide deposit at Illinois Creek, near the southwestern end of the Kaiyuh Hills in the Nulato quadrangle of western interior Alaska. According to Petroleum Information, Alaska Report (Jan. 18, 1984), Anaconda intends to expand the drilling program at Illinois Creek during the 1984 season.

Doyon, Ltd. (through its subsidiary, Tanana Asbestos), and GCO, with WGM, Inc., as operating partner, continued evaluation of the Slate Creek, Champion Creek, and two other asbestos deposits south of Eagle near the Yukon-Charley River National Preserve. Diamond drilling yielded 12inch-diameter cores for assessing fiber length and quality, as well as other information on the character of the deposits. According to articles in the Anchorage Times and the Fairbanks Daily NewsMiner, reserves include 61 million tons of 5 to 6 percent fiber, and potential ore-grade material may exceed 140 million tons. At least $\$ 14$ million has been spent on exploration and evaluation so far. Potential development through open-pit mines is contingent on market conditions, which currently are "soft." Hence, production is at least 10-15 years in the future, but it probably will be integrated with other potential developments on Doyon Corporation lands, including the upper Salcha River tungsten deposits and coal and oil deposits in the Kandik basin.

Resource Associates of Alaska (RAA, recently purchased by Nerco Minerals Co.), as operator in a joint venture with Anaconda, continued to explore and drill on extensive claim blocks covering polymetallic massive sulfide deposits in the Delta district of the eastern Alaska Range. More than 35 prospects have been identified, and more than $\$ 10$ million had been expended in their evaluation through 1982 (Eakins and others, 1983). The characteristics of the deposits are similar in many respects to those in the Ambler district of the southwestern Brooks Range and were described in a paper at the Alaska Miners Association Annual Convention in October (Nauman, 1983).

After more than 10 years of exploration and claim assessment in the Wrangell Mountains, Cooper Industries and Geneva-Pacific Corp. reliquished 


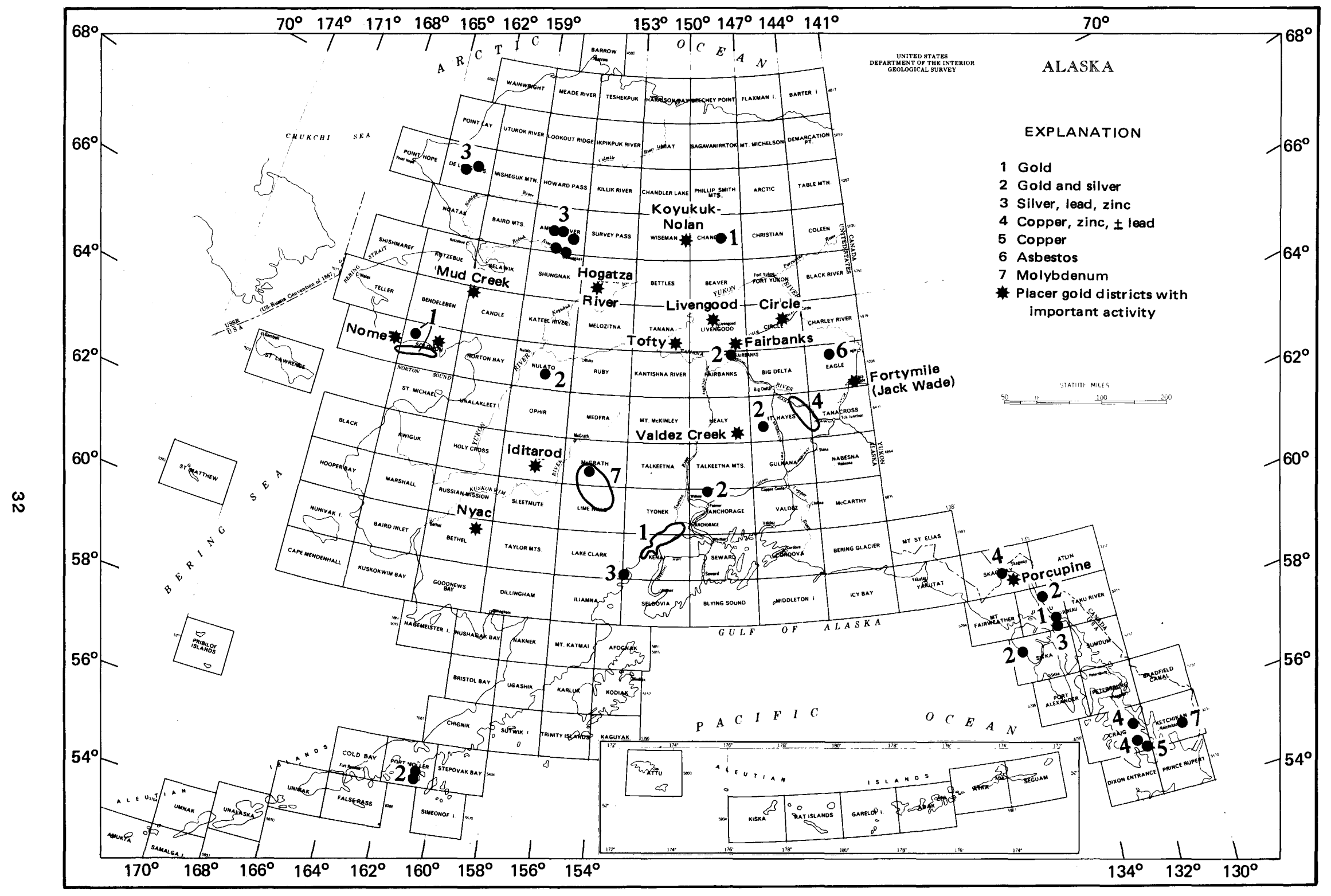

Figure 7.--Areas of important industrial activity for nonfuel minerals. 
Table 5.-- Areas of industry activity for nonfuel minerals. Locality numbers are taken from figure 7

\begin{tabular}{|c|c|c|}
\hline $\begin{array}{l}\text { Locality } \\
\text { number }\end{array}$ & $\begin{array}{l}\text { Commod- } \\
\text { it i es }\end{array}$ & $\begin{array}{l}\text { Quadrangle and } \\
\text { locality name }\end{array}$ \\
\hline 1 & $\begin{array}{l}\text { placer } \\
\text { gold }\end{array}$ & $\begin{array}{l}\text { Nome quadrangle: Nome district; Solomon quadrangle: Big } \\
\text { Hurrah, Council district; Chandalar quadrangle: Chandalar } \\
\text { district (with antimony); Juneau quadrangle: A-J and } \\
\text { Gastineau mines } \\
\text { Livengood quadrangle: Livengood district; Healy } \\
\text { quadrangle: Valdez Creek; Kenai quadrangle: Cook Inlet } \\
\text { shoreline; Skagway quadrangle: Porcupine }\end{array}$ \\
\hline 2 & $\begin{array}{l}\text { Gold } \\
\text { and } \\
\text { silver }\end{array}$ & $\begin{array}{l}\text { Nulato quadrangle: Illinois Creek (with copper) } \\
\text { Fairbanks quadrangle: Cleary Sumit, Ester Dome } \\
\text { Mount Hayes quadrangle: Zackly (with copper \& tungsten) } \\
\text { Port Mbller quadrangle: Apollo Mine, Unga Island } \\
\text { Juneau quadrangle: Berners Bay, Kensington Mine, Jualin Mine } \\
\text { Sitka quadrangle: Chichagof area }\end{array}$ \\
\hline 3 & $\begin{array}{l}\text { Zinc, } \\
\text { lead, } \\
\text { and } \\
\text { silver }\end{array}$ & $\begin{array}{l}\text { DeLong Mountains quadrangle: Red Dog, Lik, and Wulik River area } \\
\text { (with barium) } \\
\text { Ambler River quadrangle: Ambler district } \\
\text { Kenai quadrangle: Johnson Camp (with gold) } \\
\text { Juneau quadrangle: Greens Creek (with gold), Admiralty Is land }\end{array}$ \\
\hline 4 & $\begin{array}{l}\text { Copper, } \\
\text { zinc, } \\
\pm \text { lead }\end{array}$ & $\begin{array}{l}\text { Mount Hayes and Tanacross quadrangles: Delta district (with gold) } \\
\text { Skagway quadrangle: Glacier Creek (with silver and barium) } \\
\text { Mbunt Henry Clay area (with cobalt) } \\
\text { Craig quadrangle: Twelvemile Arm (with gold), Salt Chuck mine } \\
\text { (with platiunum-group metals) }\end{array}$ \\
\hline 5 & Copper & Craig quadrangle: Niblack (with gold and silver) \\
\hline 6 & Asbestos & Eagle quadrangle: Fortymile district \\
\hline 7 & $\begin{array}{l}\text { Molyb- } \\
\text { denum }\end{array}$ & $\begin{array}{l}\text { McGrath and Lime Hills quadrangles: Big River area (with lead, } \\
\text { (zinc, and precious metals) } \\
\text { Ketchikan quadrangle: Quartz Hi } 11\end{array}$ \\
\hline
\end{tabular}

title to 502 copper-silver claims (about 10,000 acres) within the Wrangell-Saint Elias National Park and Preserve to the Federal government.

Anaconda Minerals Co. continued exploratory drilling at their Johnson property, a lead-zincsilver-gold massive sulfide occurrence near Mount Iliamna on the Alaska Peninsula. The land is owned the Cook Inlet Region, Inc., Native group, and has the potential to be a major deposit. It will be tested by additional drilling in 1984 .

Exploration in the summer of 1983 by Falconbridge Nickel Mines, Ltd., (a subsidiary of Canadian Superior Oil) and Geddes Resources, Ltd.( a Canadian company), established through extensive drilling the presence of substantial amounts of gold in the Windy-Craggy copper-cobalt deposit in British Columbia, according to reports in Petroleum Information, Alaska Report (April 6, 1983, and Jan. 11,1984 ) and Northern Miner (Oct. 13, 1983). Any eventual production would be transported to tidewater in Alaska. The operators also drilled at the nearby Maid of Erin property. In January 1984,
Falconbridge transferred its 51 percent interest in the Windy-Craggy property to Geddes for net production royalties of 22.5 percent, should the property go into production (Western Miner, January 1984). The favorable exploration results have led to intensified exploration on both sides of the International Boundary in the Mount Henry Clay area 3540 miles west-northwest of Haines. Field crews of Stryker Resources (Canada), BCMC, C. C. Hawley and Associates, HIMCO, and Molycorp were active in the region, and claims were located in the Glacier Creek area late in 1983.

HIMCO explored massive silver-base metal sulfide deposits on Mansfield Peninsula and drilled the Pyrola deposit on western Admiralty Island. Several companies, including HIMCO, BCMC, Nicorp, and Duval (a subsidiary of Penzoil), were exploring in the Duncan Canal, southern Kupreanof Island, and eastern Kuiu Island areas for base and precious metal deposits.

Noranda Exploration, Inc., continued drilling and other exploratory work on stratiform massive 
sulfide deposits near Niblack Anchorage west of Moira Sound. Cominco and Anaconda also are interested in this area. Older reports show that 1.4 million pounds of copper, 11,000 ounces of gold, and 15,000 ounces of silver were shipped from the Niblack Mines, mostly before 1910 . Noranda also investigated stratiform massive sulfide prospects near the south end of Dall Island and in other parts of southeastern Alaska.

Orbex Minerals continued a limited exploration at the Salt Chuck Mine west of Kasaan. From about 1907 to 1941 , the mine produced copper ore and copper concentrates that carried significant values in gold, palladium, and platinum. Initial production was hand-sorted bornite-chalcopyrite ore that was shipped to local and British Columbia smelters; copper concentrates were produced after milling facilities were installed. After the palladium and platinum-group metal values in the ore were identified late in the operating life of the mine, concentrates were shipped to smelters in the eastern States that would pay for the palladium content. The approximate average content of the ore is listed by the Geological Survey as 0.9 percent copper and 0.025 ounces/ton gold, 0.12 ounces/ton silver, 0.053 ounces/ton palladium, and a smaller amount of platinum.

\section{OTHER INDUSTRY BEDROCK ACTIVITIES IN PRECIOUS METALS IN. 1983}

Locations of these deposits are shown on figure 7 , and they are listed on table 5 .

Drilling and trenching by C.C. Hawley and Associates, in partnership with Anaconda, at the Big Hurrah lode gold and tungsten mine on the Seward Peninsula has indicated the potential for renewed production through an open-pit and subsequent underground operation. The Big Hurrah produced more than 9,300 ounces of gold between 1904 and 1907, according to "Mineral and Water Resources of Alaska", a report prepared by the Geological Survey in 1964 for the Congressional Committee on Interior and Insular Affairs.

In the Chandalar area of the southeastern Brooks Range, development continued on gold lodes at and near the Little Squaw Mining Co. property, but the mill did not operate during 1983 .

Near Fairbanks, exploration and development continued at several lode gold properties. On their Ester Dome claims, St. Joe American (a subsidiary of Fluor) continued predevelopment work at a reduced level at the Ryan property. Also on Ester Dome, Silverado Mines, Ltd., through its operator, T.C.A., Inc., is readying the Grant Mine for reopening and was expanding and modifying the mill; 1984 will bring an increased exploration and development program (Sims, 1984). Placid Oil Co. drilled and performed underground development work on gold deposits in the Cleary area north of Fairbanks. Mohawk Resources Alaska, Inc., and Alaska Mineral Services also were exploring lode properties in the Cleary Summit area. A 100ton/day-capacity ore concentrating mill near Fairbanks will be opened in early 1984 by Mohawk and will be available for custom processing of gold, silver, lead, and zinc ores.

RAA, in a joint venture with Teton Exploration Drilling, Inc. (a subsidiary of United Nuclear Corp.), continued to drill the Zackly copper-gold-silver skarn deposit in the Mount Hayes quadrangle of the eastern Alaska Range.

The Mineral Division of Hunt Oil Co. continued exploration of several claim groups that were located during geologic mapping and prospecting that began in 1981 in the Big River drainage in southwestern Alaska south of MeGrath. The commodities of interest at various prospects are gold, silver, molybdenum, lead, zinc, tin, and tungsten. Anaconda also has continued high levels of exploration and claim staking in southwestern Alaska, but no results have been published.

In southern Alaska, Enserch Exploration, Inc., continued exploration and development work with two underground drilling crews at the Independence Mine north of Palmer and also milled a minor quantity of high-grade gold ore from the mine. In addition, the company continued a diamond-drilling program to evaluate the Golden Zone property near Cantwell and explored in the Denali State Park area.

On Unga Island south of the Alaska Peninsula near Sand Point, Alaska Apollo Gold Mines, Ltd., continued exploration and evaluation of the Apollo and Sitka Mines and adjacent vein systems. Apollo continued mapping surface geology, reopened and mapped old underground mine workings, and drilled about 20,000 feet. This work indicated greater reserves and substantiated that the main vein extends to a depth of at least 1,200 feet and may be widening with depth. Exploration drilling on the Shumagin vein indicated a major new ore zone, traceable over a length of at least 2,000 feet (Woodman, 1983; Northern Miner, March 28, 1984). The delineation of two other mineralized areas south of the Apollo Mine indicates that the Apollo vein system is a minimum of 3 miles long (Northern Miner, March 1983). Drill holes and underground sampling have confirmed significant values in silver, lead, zinc, and copper. Two other companies, Teton and RAA (on behalf of Nerco Minerals Co.), are actively exploring and drilling in the area, at Unga and Popof Islands, and on the nearby mainland in the Pyramid Peak and Mount Dana areas. Some diamond drilling was performed on claims 4 miles north of the Apollo block of claims.

Placid Oil Co. continued drilling and other work at their Kensington-Comet gold-silver prospect on Sherman Creek in Berners Bay north of Juneau. Placid is expected to request permission from the U.S. Forest Service to construct a road from the beach to the prospect site. In the same area, BCMC drilled a gold-bearing shear zone at the Jualin mine, 
which is owned by the Hyak Mining Co.

Barrick Resources Corp. (a Canadian company) started preliminary lease negotiations with the City and Borough of Juneau and Alaska Electric Light and Power, co-owners of the Alaska-Juneau Mine and the Treadwell group of mines near Juneau. Barrick is seeking a long-term lease to cover the exploration, development, and production phases of a proposed large-scale gold mining and milling project that will reopen the former low-grade, large-volume mines at Juneau. Barrick estimates that $\$ 1$ billion in gold is still in place but that it may take a decade or more to determine the feasibility of redeveloping the mines (Anchorage Times, Oct. 16, 1983).

Queenstake Resources, Ltd. (a Canadian company), acquired an option from Exploration Ventures Company to earn a 50-percent interest in the Chichagof Mine for completing a \$1.3-million phased surface and underground exploration. and rehabilitation project by December 31, 1987 . Exploration in 1984 will concentrate on locating blind ore shoots and testing old mill tailings (Northern Miner, Dec. 15, 1983). In 1983, principal expenditures were for reopening the main adit. The property is on Klag Bay on the west side of Chichagof Island, 52 miles northwest of Sitka. According to Exploration Ventures, only about 2,000 feet of the 10,000-foot Chichagof fissure was mined between 1905 and 1942 to produce 647,708 troy ounces of gold from 596,478 tons of ore (1.09 ounces/ton) (Northern Miner, May 5, 1983). Between 1942 and 1973, various leasors produced some gold and silver from cleanup operations at the mill and refinery and by re-treating small lots of tailings. The company believes that there remain about 400,000 tons of tailings averaging 0.11 ounces/ton gold.

Enserch continued exploration at the HirstChichagof Mine near the head of Kimshan Cove about 2 miles north of Chichagof. Part of the main haulage adit was reopened through several caved areas, and some exploratory work was completed. From discovery in 1905 until early 1943, production was more than 140,000 tons of ore yielding about 131,000 troy ounces of gold and 33,000 ounces of silver. In 1950 and 1954 , mill cleanup and tailings treatment yielded 121 ounces of gold. Over the life of the mine, gold values per ton of mill feed averaged about 1.0 ounce, of which 0.86 ounce/ton was recovered.

Exxon Minerals Co. evaluated a block of 69 lode gold claims just southwest of the head of Twelvemile Arm and another block of 318 lode claims east of the arm on Prince of Wales Island. Exxon also examined several copper-base metal prospects in that general area.

INDUSTRIAL PLACER ACTIVITIES IN PRECIOUS METALS.IN 1983

Locations for these deposits are shown on figure 7.
Placer gold production in 1983 in Alaska was about 169,000 troy ounces, somewhat less than in 1982. According to preliminary information, regions of the State ranked in order of decreasing production as follows: (1) eastern interior, (2) western interior, (3) southern, (4) southwestern, (5) northern, and (6) southeastern. There were successful large and small mechanized gold placer operations in most of the mining districts that were productive in 1982. The following paragraphs will emphasize only developments that are new or where significant improvement or decline in production has occurred.

Nome's future, like its past, may be in gold mining. The Alaska Gold Company increased the activity of its 9-cubic-foot No. 5 and No. 6 dredges near Nome-as well as its 7-cubic-foot Hogatza River dredge near Hughes--on its 18,000-acre holdings. According to reports in the Anchorage Daily News (Oct. 17, 1983), in the summer of 1983 the company dredged more than 2 million cubic yards and produced from 15,000 to 18,000 ounces of gold, a beginning on the proven reserves of more than 1 million ounces.

Noranda Exploration, Inc., drilled an unusual buried stream and shoreline placer gold deposit in the Mud Creek area near Candle on the northern Seward Peninsula and delineated 71,000-75,000 ounces of gold; the claim will probably be leased to a placer operator. The property was described at the Annual Meeting of the Alaska Miners Association (Robison, 1983).

Two offshore dredging operations were proposed for the Norton Sound area for 1983, but neither was able to commence production, as the National Audubon Society and the Bering Straits Coastal Resources Board, representing 18 communities in the region, filed suit to enjoin the Environmental Protection Agency (EPA) from issuing permits until environmental concerns were resolved (Petroleum Information, Alaska Report, Jan. 28, 1983). One of these operations, Coastal Exploration of Kasilof, Alaska, applied for permits to carry out a trench dredging operation on 28 claims to explore for gold in the nearshore between Nome and Golovnin Bay. The company proposed to move 112,000 cubic yards of material in water as deep as 18 feet. The other operation, Phoenix Marine Engineering, as the operator for Aurick Offshore Mining Co., applied in April 1983 for a Corps of Engineers permit to process up to 10 million cubic yards of material from a 1,288-acre site at a depth of 45-50 feet beneath Norton Sound. Activities were stalled until September, when the company won a permit hearing and moved its barge-mounted, cutter-head dredge and recovery units to the mouth of Daniels Creek, near Bluff, preparatory to mining of fshore channel extensions of the creek. However, a severe storm on September 26 drove the two operating units ashore. The two barges were beached by heavy equipment, but equipment losses were at least $\$ 1$ million. 
Eveco, Inc., of Fairbanks continued its development at "Too Much Gold Hill," Mile 9, Steese Highway, which combines the production of placer gold and marketing of coarse rock from the trommel screen and finer material from the sluice box for local construction uses. The owners predict that the 60-acre mine, in an area that had drift mining in the early 1900 s, will have a life of about 8 years (Alaska Construction and Oil, September 1983).

Galaxy Minerals (a Canadian company) was formed in early 1983 to acquire and operate a placer mine near Livengood, but production was only 80 percent as great as expected, operating costs were significantly higher than expected, and grades at depth were lower than anticipated. New drilling may be required before a decision is made to continue the operation in 1984 (Northern Miner, Sept. 22 and Oct. 23, 1983).

In southwestern Alaska, the NYAC dredge failed to operate in the Tuluksak River area in 1983. Noranda Exploration, Inc., cancelled funding for its joint venture with Northland Gold Dredging because the latter was unable to obtain permits from the Corps of Engineers early enough in the season. Permit delays occurred because the State of Alaska and the EPA alleged violations in the 1981 and 1982 mining seasons in the Tuluksak River, which is a salmon-spawning drainage and a subsistence fishery for residents of the lower Kuskokwim region. Tardy start-up would have made the 1983 season uneconomical (Petroleum Information, Alaska Report, May 11, 1983; Alaska Construction and Oil, September 1983). Permit requests for operations planned in 1984 include diverting the flow of Granite Creek in order to dredge the dry channel and the construction of five settling ponds and retention dikes. According to reports in the Anchorage Times (Jan. 27, 1984), Northland expects eventually to move the dredge down the Tuluksak River to the bottom of the mining claims, then to work back upstream in a major, 6,000-foot-long, 125-foot-wide diversion channel.

Denali Mining Co. has leased its Valdez Creek placer gold property on the south side of the central Alaska Range to a Canadian joint venture group, consisting of Camindex Mines (35 percent), Barrick Resources (25 percent), Talcorp (25 percent), and Sullivan Mines, Inc. (15 percent). The 1,200-acre property has produced 27,000 ounces of gold since its discovery in the early 1900s. A $\$ 1.2$-million exploration program in 1983 included 10,300 feet of drilling and delineated proven and probable reserves in two gravel channels of 513,000 cubic yards grading 0.15 ounces/cubic yard, including about 213,000 cubic yards grading about 0.2 ounces of gold in channel A (Northern Miner, Sept. 29, 1983, and Jan. 19, 1984). Eighty-five percent of the property still is unexplored, but project consultants state that the claims may contain as much as $\mathbf{5}$ million cubic yards of pay gravel at a grade similar to that in present reserves.

Aspen Exploration Corp. has approximately $\mathbf{5 0 0}$ requests pending before the Alaska Department of Natural Resources for offshore prospecting permits, whereby the company proposes to carry out precious metal sampling along both shores of upper Cook Inlet between Kalgin Island and Knik Arm each summer through 1985 (Petroleum Information, Alaska Report, May 4, 1983). Aspen's requests will have to be reduced to no more than 300,000 acres to satisfy legislative mandates passed in 1982. In order to help to judge which applications to delete, Aspen conducted aerial magnetic surveys over Cook Inlet in the summer of 1983. Aspen proposes to obtain samples from 31 areas as much as 1,000 yards offshore by drilling from a boat or barge; by core-drilling from between low and high tide lines; and by digging test pits on beaches with a backhoe (Alaska Construction and Oil, September 1983).

Also in the Anchorage area, Horn Resources Corp. acquired RDM Corp., which has leases on sand, gravel, and placer gold in 1,310,000 acres in the Anchorage area, including Cook Inlet tidelands. The company claims that the lease holding may contain up to $\$ 2.5$ billion in gold and that new technology makes gold recovery possible (Seattle Times, Oct. 6, 1983).

The only mechanized placer operation in southeastern Alaska in 1983 was in the Porcupine district northwest of Haines, an historic producer of placer gold. No results of the work have been announced yet.

In Alaska's capital, two companies, Taku Mining and Juneau Mining Co., have announced plans to perform exploratory work on tailings from the old A-J and Alaska Gastineau mines to determine if they can be reworked at a profit. The tailings are estimated to contain 900,000 ounces of fine gold, making the potential worth of A-J tailings approximately $\$ 300$ million and Gastineau tailings $\$ 94$ million. Juneau Mining already has built a plant to treat tailings from the Gastineau mill at Thane, about 4 miles south of Juneau. These tailings were deposited on and adjacent to the beach on the east side of Gastineau Channel. The company has applied to process 3 million cubic yards over 8 years from a 16-acre area. A cutter-head dredge will deliver tailings by pipeline to a shore-basedscreening and concentrating plant. Concentrates will be treated in a thiourea leaching process for recovery of gold and silver values. Plant shakedown and preliminary runs were started in late November, about the anticipated end of a normal operating season.

SAND AND GRAVEL

According to the Alaska Division of Geological and Geophysical Surveys, about 50.5 million short tons of sand and gravel were mined in 1983 (table 3). Active sand and gravel pits are located at regular intervals, depending on availability of 
materials, along major roads and the Alaska Railroad because of the continuous need for these materials in maintenance. Other primary users of sand and gravel were companies building the offshore gravel drilling pads in the Beaufort Sea and municipal and private construction. The Alaska Economic Report for Aug. 6, 1983, notes that almost three-quarters of the Alaska Railroad's 1983 tonnage was sand and gravel hauled from pits near Palmer to meet demands in Anchorage, where gravel pits have been closed by planning authorities. The Alaska Journal of Commerce and Pacific Rim Reporter reported in April 1984 that 4.4 million tons of gravel were transported by the railroad, as compared to slightly more than a million tons of coal and petroleum products combined. The dollar value of sand and gravel is second only to oil and gas produced in Alaska.

\section{REFERENCES CITED}

Alaska Construction and Oil, P. O. Box 101980, Anchorage, AK 99510.

Alaska Economic Report, published by Alaska Information Service, 3037 South Circle, Anchorage, AK 99507.

Alaska Department of Natural Resources, 1983, DNR locatable minerals management study: 30 p. (October 1983).

Alaska Journal of Commerce and Pacific Rim Reporter, 715 L Street, Anchorage, AK 99501.

Anchorage Daily News, 200 Potter Drive, Anchorage, AK 99502.

Anchorage Times, 840 West 4th Avenue, Anchorage, AK 99501.

Berger and Associates, 1983, The role of placer mining in the Alaska economy: Alaska Department of Commerce and Economic Development, Office of Mineral Development, 22 p. (March 1983).

Duval, David, 1983, Cominco's Red Dog certain to become mine: Northern Miner, v. 69, no. 6, p. 1-2.

Eakins, G. R., Bundtzen. T. K., Robinson, M. S., Clough, J. G., Green, C. B., Clautice, K. H., and Albanese, M. A., 1983, Alaska's mineral industry, 1982: Alaska Division of Geological and Geophysical Surveys Special Report 31, 63 p.

Haney, J. M., 1982, Geology of the McKinley Lake gold prospect area, Chugach National Forest, south central Alaska: New Mexico Institute of Mining and Technology, unpub. Master's thesis, 42 p. and appendix.

Mining Engineering, published by American Institute of Mining, Metallurgical and Petroleum Engineering, Inc., Littleton, CO 80127.

Nauman, C. R., 1983, Geology and mineralization of the Delta massive sulfide district-An update: The Alaska Miner, Journal of the Alaska Miners Association, v. 11, no. 12, p. 11.

Northern Miner, Suite 301, 229-11th Avenue S.E., Calgary, Alta., T2G OY 1

Petroleum Information, Alaska Report, published by Petroleum Information, a subsidiary of A. C. Nielson, P. O. Box 102278, Anchorage, AK 99510.

Plahuta, J. T, Young, L. E., Modene, J. S., and Moore, D. W., 1983, Geology of the Red Dog lead-zinc deposit: The Alaska Miner, Journal of the Alaska Miners Association, v. 11 , no. 12 , p. 11 .

Robison, Jim, 1983, Mud Creek, (northern Seward Peninsula)-A gold placer prospect: The Alaska Miner, Journal of the Alaska Miners Association, v. 11, no. 12, p. 10.

Seattle Times Co., P. O. Box 70, Fairview Avenue N. and John St., Seattle, WA 98111.

Sims, John, 1984, Alaska mining in '84-Optimism returns: Alaska Construction and Oil, v. 25, no. 1 , p. 40-50, 52, 54 .

Southeastern Log, Box 7900, Ketckikan, AK 99901

Tikkanen, George, 1983, Red Dog zinc-lead potential immense: Northern Miner, v. 69, no. 24, p. B4-B5.

Western Miner Press, Ltd., 1201 Melville Street, Vancouver, British Columbia, V6E $2 \times 9$.

Woodman, Betzi, 1983, Shumagin Island gold mine shows promise of good returns: Alaska Construction and Oil, v. 24, no. 9, p. 28, 30 .

\section{CRITICAL AND STRATEGIC MINERALS}

In a meeting of the Senate Energy Committee in May 1983, Alaska's Senator Frank Murkowski stressed the need for designation of a lead Federal agency to oversee domestic development of strategic minerals (Anchorage Times, May 20, 1983). Although 18 of 29 minerals that currently are considered to be strategic are found in Alaska, only tin and platinum are produced-but with large annual variations in amounts. Senator Murkowski suggested that the effort to streamline regulatory, trade, and developmental policies by the 20 agencies that oversee Alaska's lands might remove some of the barriers to development.

Promising resources of cobalt, chromium, nickel, tin, tungsten, and platinum-group elements exist in Alaska. Numerous companies in 1983 were actively attempting to define better known occurrences or were exploring for new ones. Although the potential of these resources seems promising in the long run, unfavorable land status, the inadequacies or lack of transportation, the high costs of development, and the remoteness from markets continue to make their development unlikely in the near future. 


\section{ACTIVITIES BY FEDERAL AGENCIES IN 1983}

U.S. Geological Survey.-Activity continued in four projects in AMRAP that pertain to critical and strategic minerals. A Level IV study continued on layered mafic ultramafic rocks in interior Alaska that contain significant concentrations of chromium, nickel, and platinum-group elements. Fieldwork in 1983 concentrated on rocks in the Mount Hurst, Yuki River, and Kanuti River areas. A Level III geological, geophysical, and geochemical study of the Yukon-Koyukuk region continued in 1983; fieldwork included sampling of tin-bearing rocks in the Zane Hills and Indian Mountain of western interior Alaska. A Level III mineral resource assessment is being prepared for the Solomon and Bendeleben quadrangles of the central Seward Peninsula, an area which has the potential for the occurrence of many commodities-most notably tin. A Level IV project on tin and tungsten occurrences in the Circle district began in 1983, and additional tin commodity studies will begin on the Seward Peninsula in 1984. Locations of these projects are shown on figure 5 , and project titles are listed on table 4.

Bureau of Mines.--Statewide reconnaissance investigations continued in 1983 on reported occurrences of cobalt, chromium, and the platinumgroup metals. Investigations of tin, niobium, and tantalum were started. Figure 8 shows the areas investigated; table 6 lists the localities and prospect names in each of the areas.

Bureau of Mines reconnaissance investigations do not include drilling or detailed quantitative sampling. The first phase of a reconnaissance investigation is designed to determine the mineralogy and geologic setting of each occurrence or group of occurrences and to estimate their extent and grade. Normally this requires at least two visits to an area. First, the area is mapped, and samples are collected and quantitatively analyzed. Industry data and facilities are used wherever possible. If the initial investigation indicates that a deposit, or group of deposits, has potential national significance, then bulk samples are obtained and analyzed to determine metallurgical characteristics and to estimate recoverability. The metallurgical work is performed at the Bureau of Mines Albany Research Center in Albany, Ore. Special analyses are made at the Juneau laboratory or in other appropriate laboratories.

Reports covering such investigations completed during 1983 include the results of field evaluation and beneficiation tests of chromite occurrences in interior Alaska (Foley and McDermott, 1983; Dahlin and others, 1983) and field investigations of critical and strategic minerals in the Klukwan mafic/ultramafic complex in southeastern Alaska (Still, 1983). These reports are listed with Bureau reports at the back of this circular.
INDUSTRY AND STATE ACTIVITY IN 1983

The following are highlights of industrial activity in critical and strategic minerals in 1983. Locations are shown in figure 9 and further defined in table 7. A brief reference to State of Alaska activity is included.

According to Petroleum Information, Alaska Report (April 6 and 13, 1983), Anaconda Minerals Co. continued to explore in 1983 its lode tin discovery at Kougarok Mountain in the central Seward Peninsula, including additional drilling and surface stripping of overburden to expose the lode. Anaconda has requested permission to construct a 6,000-foot airstrip and a 12-mile spur road from the Taylor highway to gain access to the property.

Lost River Mining, the only significant primary tin producer in the United States, increased production a few percent over the 1982 run at its placer operation on Cape Creek.

Interest by HIMCO and other companies in tungsten and precious metals in the Yukon-Tanana Upland remained high in 1983. They explored in the Circle quadrangle and at Twin Mountain in the Charley River quadrangle at the site of a skarn deposit of tungsten that was discovered in $\mathbf{1 9 8 2 .}$

Noranda and HIMCO contracted for additional detailed mapping at the Coal Creek tin prospect 5 miles southwest of Hurricane near the Alaska Railroad and the Parks Highway. According to a paper given at the Alaska Miners Association meeting (Thurow, 1983), the greisen deposit consists of sheeted veins extending 1,400 by 200 feet horizontally and 600 feet vertically.

The Salmon River dredge near Goodnews Bay in southwestern Alaska was operated for a short time in the summer of 1983 by Hanson Properties of Spokane, Wash., but no production of platinumgroup metals was reported.

Alyu Mining Co., Molycorp (a subsidiary of Union Oil Co.), and HIMCO were exploring in the Glacier Creek-Haines area of southeastern Alaska. This area has the potential for cobalt-enriched base metal deposits similar to the Windy-Craggy deposit a few miles across the International Boundary in Canada. (See the section describing nonfuel minerals for additional information.)

Galactic Resources, Ltd., and Cornucopia Resources, Ltd., acquired from the Aleco Mining Group the Bohemia Basin and Mirror Harbor nickelcopper-cobalt deposits located on Chichagof and Yakobi Islands, northern southeastern Alaska. These properties are one of the few proven reserves of nickel sulfide mineralization in the United States and have drilled reserves of 20 million tons grading 0.37 percent nickel, 0.22 percent copper, and 0.02 percent cobalt. The deposit is potentially mineable by surface mining and has a 2.5:1 stripping ratio. In 1983 , the new owners drilled 3,080 additional feet at Bohemia Basin and 2,650 feet at Mirror Harbor 


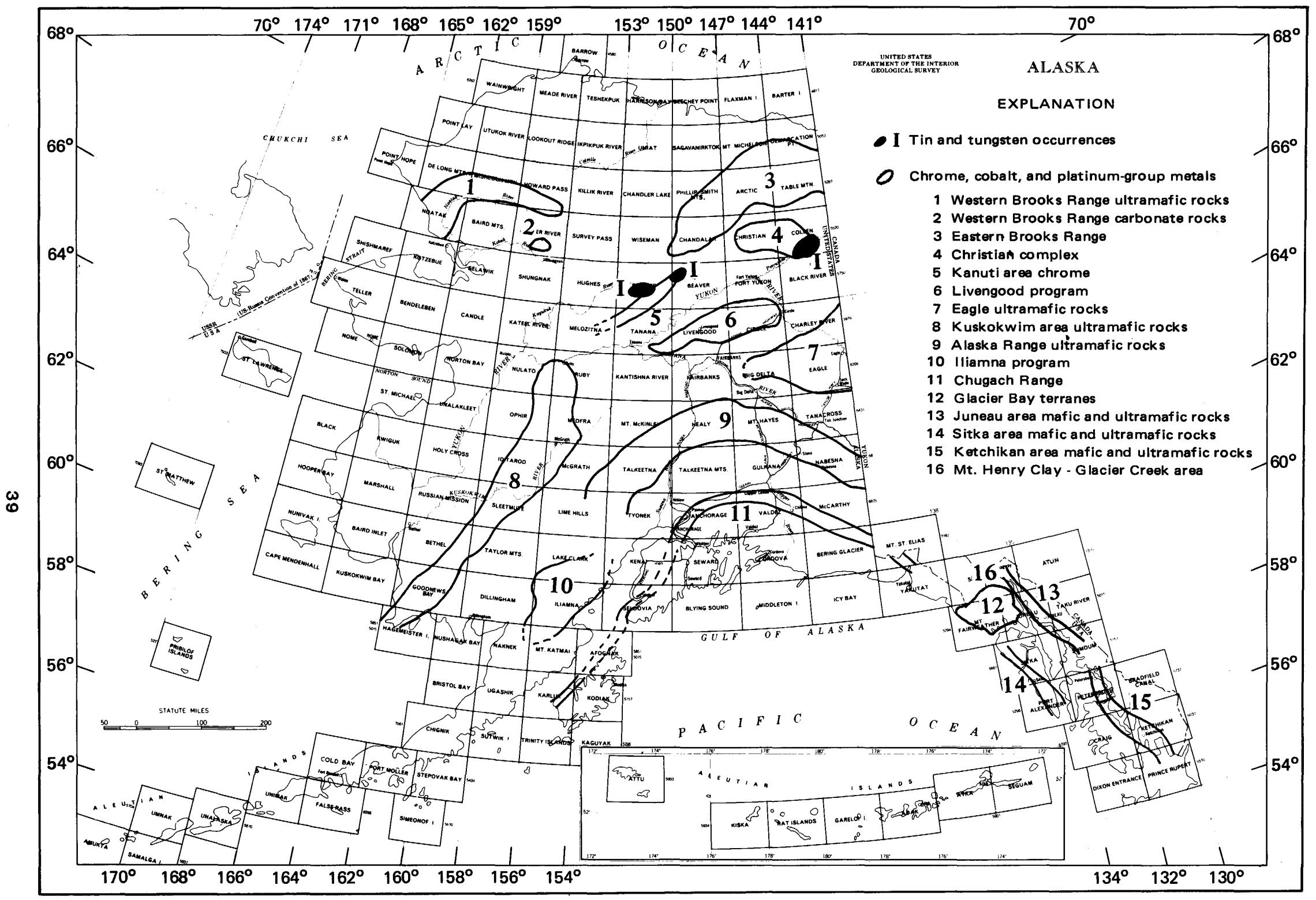

Figure 8.-Areas of Bureau of Mines' investigations for critical and strategic minerals in 1983. See table 6 for locality or area names. Dashed lines indicate inferred extensions of areas containing these minerals. 
Table 6.- Locality and prospect names to accompany figure 8. Further information about these localities is available from the Bureau of Mines Alaska Field Office in Juneau

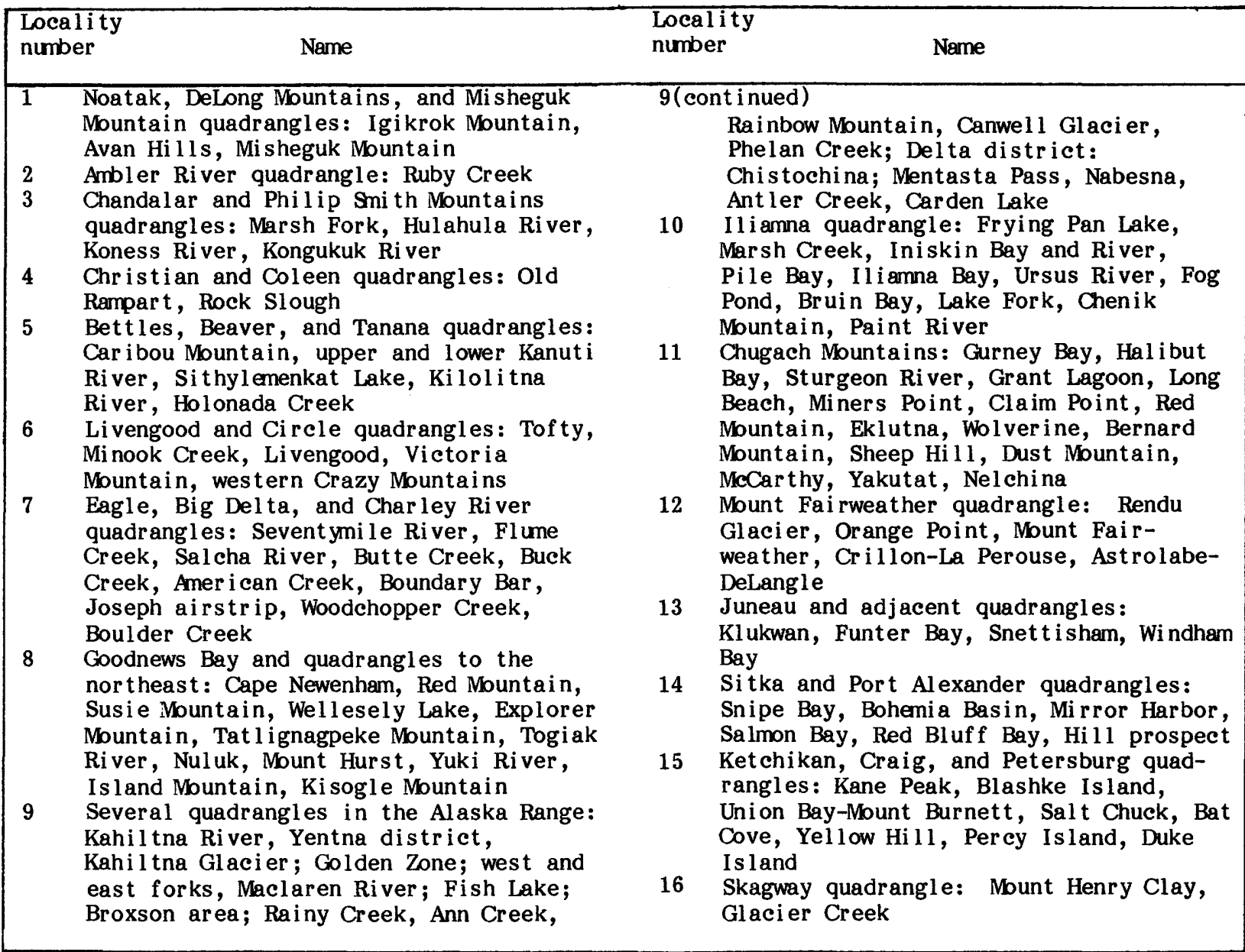

and sampled and mapped the deposits in detail. The nearby Takanis and Flapjack deposits also have considerable inferred ore. Other untested occurrences within short distances of the Bohemia Basin deposit-including Lake 222, Takanis Lake, and the Beach area anomaly-are good exploration targets. A joint study by the owners and the Bureau of Mines is being conducted to determine the distribution and potential recovery of platinumgroup elements, gold, and silver. A summary report of a joint Bureau of Mines-Geological Survey study of the area, "Mineral resource potential of the western Chichagof-Jakobi Islands wilderness study area, southeastern Alaska," was published in 1982 (Johnson, Kimball, and Still, 1982).

Exploration at the Salt Chuck copperpalladium-platinum mine, owned by Orbex Minerals, Ltd., continued in 1983. (See the description in the section about nonfuel minerals.)
Other areas of continuing active company exploration for critical and strategic minerals during 1983 include: for cobalt, Ruby Creek (by Bear Creek Mining Co., or BCMC); and for tin, western Seward Peninsula (Anaconda, Placid Oil Co.), Circle district (RAA), Bonnifield district (RAA and $\mathrm{BCMC}$ ), and in southwestern Alaska (Anaconda, Duval).

During 1983 the Alaska Division of Geological and Geophysical Surveys and the Minerals Industry Research Laboratory of the University of Alaska continued detailed mapping projects and studies of control of mineralization in areas of tin, tungsten, and precious metals occurrences in the Circle and Big Delta quadrangles.

\section{REFERENCES CITED}

Bundtzen, T. K., 1983, Mineral-resource modeling, Kantishna Hills - Dunkle Mine study areas, 


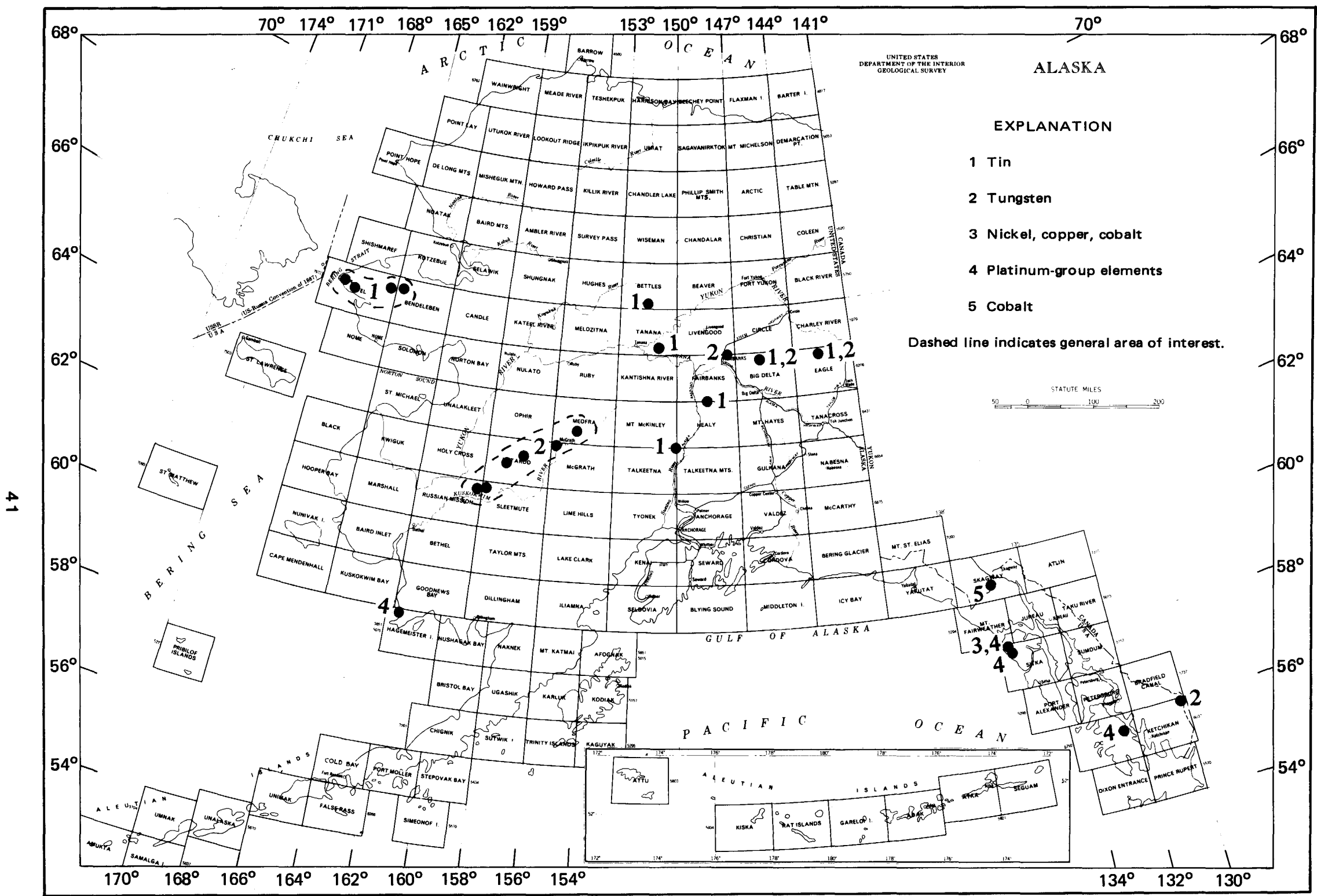

Figure 9.--Areas of industrial activity for critical and strategic minerals in 1983 and early 1984. See table 7 for locality and prospect names by quadrangle. 
Table 7.- Localities of interest for critical and strategic minerals to accompany figure 9. For further information, contact the Bureau of Mines Alaska Field Office in Juneau

\begin{tabular}{|c|c|c|}
\hline $\begin{array}{l}\text { Cormodity } \\
\text { number }\end{array}$ & Commodi ty & Local i ty \\
\hline 1 & $\operatorname{Tin}$ & $\begin{array}{l}\text { Teller quadrangle: Lost River, Cape Creek, } \\
\text { Kougarok Mountain } \\
\text { Bendeleben quadrangle: Serpent ine Hot Springs } \\
\text { Bettles quadrangle: Si thylemenkat } \\
\text { Healy quadrangle: Bonnif ield } \\
\text { Tanana quadrangle: Tof ty } \\
\text { Eagle quadrangle: upper Seventymile River } \\
\text { Talkeetna Mountains quadrangle: Coal Creek }\end{array}$ \\
\hline 2 & Tungsten & $\begin{array}{l}\text { Eagle quadrangle: upper Seventymile River } \\
\text { Fai rbanks area: Gi lmore Dome, Salcha district } \\
\text { Idi tarod and adjacent quadrangles: several } \\
\text { localities } \\
\text { Ketchikan quadrangle: Hyder }\end{array}$ \\
\hline 3 & $\begin{array}{l}\text { Ni ckel, } \\
\text { copper, } \\
\text { cobal t }\end{array}$ & $\begin{array}{l}\text { Si tka quadrangle: Bohemi a Basin, Mirror Harbor } \\
\text { (wi th plat inum-group metals) }\end{array}$ \\
\hline 4 & $\begin{array}{l}\text { Platinum- } \\
\text { group } \\
\text { elements }\end{array}$ & $\begin{array}{l}\text { Goodnews Bay quadrangle: Salmon River } \\
\text { Craig quadrangle: Salt Chuck (with copper) } \\
\text { Big Delta quadrangle: Salcha River (not shown) }\end{array}$ \\
\hline 5 & Cobalt & $\begin{array}{l}\text { Skagway quadrangle: Mount Henry Clay, Glacier } \\
\text { Creek (with silver and base metals) }\end{array}$ \\
\hline
\end{tabular}

Alaska: Alaska Division of Geological and Geophysical Surveys, Report of Investigations RI-83-12, 51 p.

Johnson, B. R., Kimball, A. L., and Still, J. C., 1982 (1983), Mineral resources of the western Chichagof and Yakobi Islands wilderness study area, southeastern Alaska: U.S. Geological Survey Miscellaneous Field Studies Map MF-1476B, 10 p., 1 sheet, scale $1: 125,000$.

Thurow, G. E., 1983, Geology of the Coal Creek tin prospect, south-central Alaska: The Alaska Miner, Journal of the Alaska Miners Association, v. 11, no. 12, p. 24.

\section{SELECTED REFERENCES}

The following lists of references released in 1983 or early 1984 contain articles that describe various aspects of mineral-related activity by Federal and other agencies or industrial concerns in Alaska. This is not a compete listing of the publications of any agency, and it does not include material about hydrology, seismicity, paleontology, or offshore geology, even though some information about these topies may have been used to prepare the listed reports or be important to some facets of mineral investigations.

The U.S. Geological Survey regularly publishes its findings in several types of reports. A monthly listing titled "New Publications of the U.S. Geological Survey" is available free from the Geological Survey, 582 National Center, Reston, VA 22092; the contents of these lists are compiled annually into a free book titled "Publications of the Geological Survey (year)." Prices and addresses of the of fices from which reports can be obtained are given in the monthly listing or are available from the Geological Survey's Public Inquiries Offices.

The Bureau of Mines also publishes a variety of reports describing the results of its investigations. The Bureau of Mines' central distribution of fice is the Branch of Production and Distribution, 4800 Forbes Avenue, Pittsburgh, PA 15213. Many Bureau of Mines reports are available through the U.S. Government Printing Office in Washington, D.C.; some are available through the National Technical Information Service in Springfield, Va. The reports listed herein and an index of the publications about mineral investigations in Alaska from 1911 through 1981 are in the Bureau of Mines' Juneau library. For information about the availability of these 
reports, contact the Chief, Alaska Field Operations Center, Box 550, Juneau, AK 99802.

Reports prepared by other Federal or State agencies that describe their activities or results of their work are generally available through the agencies' offices or at the Department of the Interior's Alaska Resources Library in the Federal Building, 701 C Street, Anchorage, AK 99513.

\section{U.S. GEOLOGICAL SURVEY}

Professional Paper

Rosenblum, Sam, and Mosier, E. L., 1983, Mineralogy and occurrence of europeum-rich dark monazite: U.S. Geological Survey Professional Paper 118l, 67 p.

\section{Circulars}

Coonrad, W. L., ed., 1984, United States Geological Survey in Alaska - Accomplishments during 1981: U.S. Geological Survey Circular 868, 162 p. The circular contains the following germane articles:

Summary of Landsat quadrangle studies in Alaska, by J. R. LeComte and others

Alaskan geochemical field laboratories, by R. M. O'Leary and J. D. Hoffman

Kivivik Creek-A possible zinc-lead-silver occurrence in the Kuna Formation, western Baird Mountains, Alaska, by Inyo Ellersieck and others

Reconnaissance geology of the northern part of the Unalakleet quadrangle rangle, by W. W. Patton, Jr., and E. J. Moll

Preliminary report on ophiolites in the Yuki River and Mount Hurst areas, west-central Alaska, by R. A. Loney and G. R. Himmelberg

Gold in Tertiary (?) rocks, Circle quadrangle, Alaska, by W. E. Yeend

Structural relations and fluid-inclusion data for mineralized and nonmineralized quartz veins in the Port Valdez gold district, Valdez quadrangle, southern Alaska, by W. J. Pickthorn and M. L. Silberman

A preliminary geochemical interpretation of the Chugach Wilderness, southern Alaska, by R. J. Goldfarb

Geochemically anomalous areas north of the Denali fault in the Mount Hayes quadrangle, southern Alaska, by G. C. Curtin and others
Mineral exploration and reconnaissance bedrock mapping using active alpine glaciers, Mount Hayes and Healy quadrangles, southern Alaska, by E. B. Evenson and others

Placers and placer mining in the Healy quadrangle, by W. E. Yeend

Listings of reports about Alaska by USGS authors

Mayfield, C. F., Tailleur, I. L., Albert, N. R. D., Ellersieck, Inyo, Grybeck, Donald, and Hackett, S. W., 1983, The Alaska Mineral Resource Assessment Program-Background information to accompany folio of geologic and mineral resource maps of the Ambler River quadrangle: U.S. Geological Survey Circular 793, $31 \mathrm{p}$.

Reiser, H. N., Brosgé, W. P., Hamilton, T. D., Singer, D. A., Menzie, W. D., Bird, K. J., Cady, J. W., LeCompte, J. R., and Cathrall, J. B., 1983, The Alaska Mineral Resource Assessment Program-Guide to information contained in folio of geologic and mineral resource maps of the Philip Smith Mountains quadrangle, Alaska: U.S. Geological Survey Circular 759, 22 p.

Stricker, G. D., 1983, Coal occurrence, quality, and resource assessment, National Petroleum Reserve - Alaska, in U.S. Geological Survey Polar Research Symposium, Abstracts with Program: U.S. Geological Survey Circular 911, p. 32 and 33.

U.S. Geological Survey, 1983, 1983 Annual report on Alaska's mineral resources: U.S. Geological Survey Circular 908, 48 p. (Prepared in cooperation with the Federal agencies that contributed to the 1984 annual report.)

1983, Scientific and technical, spatial and bibliographic data bases and systems of the U.S. Geological Survey, 1983: U.S. Geological Survey Circular 817, 4 parts.

1983, U.S. Geological Survey Polar Research Symposium-Abstracts with Program: U.S. Geological Survey Circular 911, 55 p. (Contains abstracts about petroleum, coal, and nonfuel minerals in Arctic Alaska.)

Wood, G. H., Jr., Kehn, T. M., Carter, M. D., and Culbertson, W. C., 1983, Coal resource classification system of U.S. Geological Survey: U.S. Geological Survey Circular 891, 65 p.

Bulletins

Hoare, J. M., Coonrad, W. L., and MeCoy, Scott, 1983, Summit Island Formation, a new Upper Cretaceous formation in southwestern Alaska: U.S. Geological Survey Bulletin 1529-B, 18 p.

Note: Bulletin 1374, Placer deposits in Alaska, has been reprinted. 
open-File Reports

Banet, A. C., Jr., 1983, A geochemical profile of Tunalik no. 1 well, National Petroleum Reserve in Alaska (NPRA): U.S. Geological Survey Open-File Report 83-627, 2 oversize sheets.

Bartsch-Winkler, Susan, 1983, Availability of petrographic thin-sections from measured sections and wells in Early- to LateCretaceous Nanushuk Group rocks, National Petroleum Reserve in Alaska, North Slope, Alaska: U.S. Geological Survey Open-File Report 83-608, 10 p.

Bliss, J. D., 1983, Alaska-Basic data for thermal springs and wells as recorded in GEOTHERM: U.S. Geological Survey Open-File Report 83426, 119 p.

Briggs, S. R., 1983, Geology report for proposed Beaufort Sea OCS sand and gravel lease sale: U.S. Geological Survey Open-File Report 83606, 66 p.

Carter, L. D., 1983, Engineering geologic maps of northern Alaska, Teshekpuk quadrangle: U.S. Geological Survey Open-File Report 83-634, scale 1:250,000, 1 sheet.

Cathrall, J. B., Day, G. W., Hoffman, J. D., and McDanal, S. K., 1983, A listing and statistical summary of analytical results for pebbles, stream sediments, and heavy mineral concentrates from stream sediments, Petersburg area, southeast Alaska: U.S. Geological Survey Open-File Report 83-420-A, 218 p., scale $1: 250,000,1$ sheet.

1983, Distribution and abundance of copper, determined by spectrographic analysis in the minus 80 -mesh fraction of stream sediments, Petersburg area, southeast Alaska: U.S. Geological Survey Open-File Report 83-420-B, scale $1: 250,000,1$ sheet.

1983, Distribution and abundance of copper, determined by spectrographic analysis, in nonmagnetic fraction of heavy-mineral concentrates from stream sediments, Petersburg area,southeast Alaska: U.S. Geological Survey Open-File Report 83-420-C, scale $1: 250,000,1$ sheet.

1983, Distribution and abundance of lead, determined by spectrographic analysis, in the minus 80 -mesh fraction of stream sediments, Petersburg area, southeast Alaska: U.S. Geological Survey Open-File Report 83-420-D, scale 1:250,000, 1 sheet.

1983, Distribution and abundance of lead, determined from spectrographic analysis, in nonmagnetic fraction of heavy-mineral concentrates from stream sediments, Petersburg area, southeast Alaska: U.S. Geological Survey Open-File Report 83-420-E, scale $1: 250,000,1$ sheet.

1983, Distribution and abundance of zine, determined by spectrographic analysis, in the minus 80-mesh fraction of stream sediments, Petersburg area, southeast Alaska: U.S. Geological Survey Open-File Report 83-420-F, scale $1: 250,000,1$ sheet.

1983, Distribution and abundance of zinc, determined by spectrographic analysis, in the nonmagnetic fraction of heavy-mineral concentrates from stream sediments, Petersburg area, southeast Alaska: U.S. Geological Survey Open-File Report 83-420-G, scale $1: 250,000,1$ sheet.

1983, Distribution and abundance of barium, determined by spectrographic analysis, in the minus 80 -mesh fraction of stream sediments, Petersburg area, southeast Alaska: U.S. Geological Survey Open-File Report 83-420-H, scale 1:250,000, 1 sheet.

1983, Distribution and abundance of barium, determined by spectrographic analysis, in nonmagnetic fraction of heavy-mineral concentrates from stream sediments, Petersburg area, southeast Alaska: U.S. Geological Survey Open-File Report 83-420-I, scale $1: 250,000,1$ sheet.

1983, Distribution and abundance of determinable silver by spectrographic analysis, in nonmagnetic fraction of heavy-mineral concentrates from stream sediments and in the minus 80 -mesh fraction of stream sediments, Petersburg area, southeast Alaska: U.S. Geological Survey Open-File Report 83420-J, scale $1: 250,000,1$ sheet.

1983, Distribution and abundance of detectable gold, arsenic, bismuth, and antimony in the nonmagnetic fraction of heavy-mineral concentrates and in the minus 80-mesh fraction from stream sediments. Petersburg area, southeast Alaska: U.S. Geological Survey Open-File Report 83-420-K, scale 1:250,000, 1 sheet.

1983, Distribution and abundance of tin determined by spectrographic analysis in nonmagnetic fraction of heavy-mineral concentrates from stream sediments, Petersburg area, southeast Alaska: U.S. Geological Survey Open-File Report 83-420-L, scale $1: 250,000,1$ sheet.

1983, Distribution and abundance of cadmium, determined by spectrographic analysis in nonmagnetic fraction of heavymineral concentrates from stream sediments, Petersburg area, southeast Alaska: U.S. Geological Survey Open-File Report 83-420-M, scale $1: 250,000,1$ sheet.

1983, Distribution and abundance of molybdenum, determined by spectrographic analysis, in the minus 80 -mesh fraction of stream sediments, Petersburg area, southeast Alaska: U.S. Geological Survey Open-File Report 83-420-N, scale 1:250,000, 1 sheet. 
1983, Distribution and abundance of molybdenum, determined by spectrographic analysis, in the minus 80 -mesh fraction of heavy-mineral concentrates from stream sediments, Petersburg area, southeast Alaska: U.S. Geological Survey Open-File Report 83420-0, scale 1:250,000, 1 sheet.

1983, Distribution and abundance of nickel, determined by spectrographic analysis, in the minus 80 -mesh fraction of stream sediments, Petersburg area, southeast Alaska: U.S. Geological Survey Open-File Report 83-420-P, scale $1: 250,000,1$ sheet.

1983, Distribution and abundance of nickel, determined by spectrographic analysis, in nonmagnetic fraction of heavy-mineral concentrates from stream sediments, Petersburg area, southeast Alaska: U.S. Geological Survey Open-File Report 83-420-Q, scale $1: 250,000,1$ sheet.

1983, Distribution and abundance of cobalt, determined by spectrographic analysis, in the minus $80-$ mesh fraction of stream sediments, Petersburg area, southeast Alaska: U.S. Geological Survey Open-File Report 83-420-R, scale $1: 250,000,1$ sheet.

1983, Distribution and abundance of cobalt, determined by spectrographic analysis, in the nonmagnetic fraction of heavy-mineral concentrates from stream sediments, Petersburg area, southeast Alaska: U.S. Geological Survey Open-File Report 83-420-S, scale $1: 250,000,1$ sheet.

1983, Distribution and abundance of chromium, determined by spectrographic analysis, in the minus 80 -mesh fraction of stream sediments, Petersburg area, southeast Alaska: U.S. Geological Survey Open-File Report 83-420-T, scale $1: 250,000,1$ sheet.

1983, Distribution and abundance of chromium, determined by spectrographic analysis, in the nonmagnetic fraction of heavy-mineral concentrates of stream sediments, Petersburg area, southeast Alaska: U.S. Geological Survey Open-File Report $83-420-U$, scale $1: 250,000,1$ sheet.

1983, Distribution and abundance of tungsten, determined from colorimetric and spectrographic analysis, in the minus 80-mesh fraction of stream sediment, Petersburg area, southeast Alaska: U.S. Geological Survey Open-File Report $83-420-V$, scale $1: 250,000,1$ sheet.

1983, Distribution and abundance of tungsten, determined by spectrographic analysis, in nonmagnetic fraction of heavymineral concentrates from stream sediments, Petersburg, southeast Alaska: U.S. Geological Survey Open-File Report 83-420-W, scale $1: 250,000,1$ sheet.

Clark, S. H. B., 1983, Reconnaissance geologic map of the Chugach Mountains in the Anchorage
A5 and A6 quadrangles, Alaska: U.S. Geological Survey Open-File Report 83-336, scale $1: 63,360,1 \mathrm{pl}$.

Cobb, E. H., 1983, Occurrences of zinc minerals in Alaska: U.S. Geological Survey Open-File Report $83-199,18$ p., scale $1: 2,500,000,1$ sheet.

1983, Occurrences of lead minerals in Alaska: U.S. Geological Survey Open-File Report 83-73, 21 p., 1 sheet.

Cobb, E. H., and Cruz, E. L., 1983, Summaries of data and lists of references to metallic and selected nonmetallic mineral deposits in the Chandalar quadrangle, Alaska: U.S. Geological Survey Open-File Report 83-287, 92 p.

Curtis, S. M., Ellersieck, Inyo, Mayfield, C. F., and Tailleur, I. L., 1983, Reconnaissance geologic map of the De Long Mountains A1, B1, and part of C1 quadrangles, Alaska: U.S. Geological Survey Open-File Report 83-185, 54 p., scale 1:63,360, 2 sheets.

Dickinson, K. A., Morrone, J. F., and Roberts, M. E., 1983, Summary of radiometric anomalies in Alaska: U.S. Geological Survey Open-File Report 83-169, 1 sheet, seale 2,500,000.

Eberlein, G. D., Churkin, Michael, Jr., Carter, Claire, and Berg, H. C., 1983, Geology of the Craig quadrangle, Alaska: U.S. Geological Survey Open-File Report 83-91, 53 p., scale $1: 250,000,4$ sheets.

Ellersieck, Inyo, Curtis, S. M., Mayfield, C. F., and Tailleur, I. L., 1983, Reconnaissance geologic map of the De Long Mountains A2, B2, and part of C2 quadrangles, Alaska: U.S. Geological Survey Open-File Report 83-184, 54 p., scale 1:63,360, 2 sheets.

Foster, H. L., Laird, Jo, Keith, T. E. C., Cushing, G. W., and Menzie, W. D., 1983, Preliminary geologic map of the Circle quadrangle, Alaska: U.S. Geological Survey Open-File Report 83-170A, 32 p., scale 1:250,000, 1 sheet.

Gehrels, G. E., Berg, H. C., and Saleeby, J. B., 1983, Ordovician-Silurian volcanogenic massive sulfide deposits on southern Prince of Wales Island and the Barrier Islands, southeastern Alaska: U.S. Geological Survey OpenFile Report 83-318, 11 p.

Gough, L. P., and Severson, R. C., 1983, Chemical analyses of native soil and vegetation samples, Capps coal field, Alaska: U.S. Geological Survey Open-File Report 83-246, 58 p.

Harris, A. G., Ellersieck, Inyo, Mayfield, C. F., and Tailleur, I. L., 1983, Thermal maturation values (conodont and color alteration indices) for Paleozoic and Triassic rocks, Chandler Lake, De Long Mountains, Howard Pass, Killik River, Misheguk Mountains, and Point Hope quadrangles, northwestern Alaska and subsurface NPRA: U.S. Geological Survey OpenFile Report 83-505, 15 p. 
Jones, D. L., Silberling, N. J., Gilbert, W. G., and Coney, P. J., 1983, Tectonostratigraphic map and interpretive bedrock geologic map of the Mount McKinley region, Alaska: U.S. Geological Survey Open-File Report 83-11, scale $1: 250,000,2$ sheets.

Kelley, J. S., and Peterson, D. M., 1983, Preliminary bibliography of geologic literature on the Killik River and Chandler Lake quadrangles, north-central Brooks Range, Alaska: U.S. Geological Survey Open-File Report 83232, $31 \mathrm{p}$.

King, H. D., and Tripp, R. B., 1983, Multi-element maps showing the distribution and relative amounts of selected elements in four geochemical sampling media, Medfra quadrangle, Alaska: U.S. Geological Survey Open-File Report 80-811-M, 4 sheets.

King, H. D., Cooley, E. F., and Spiesman, D. L., Jr., 1983, Distribution and abundance of arsenic and bismuth in nonmagnetic and moderately magnetic heavy-mineral con-centrate samples and arsenic in minus 80 -mesh stream sediment and ash of aquatic bryophyte samples, Medfra quadrangle, Alaska: U.S. Geological Survey Open-File Report 80-811-K, 3 sheets.

King, H. D., Cooley, E. F., Gruzensky, A. L., and Spiesman, D. L., Jr., 1983, Distribution and abundance of gold and silver in nonmagnetic and moderately magnetic heavy-mineral concentrate and minus 80-mesh stream-sediment samples and silver in ash of aquatic bryophyte samples, Medfra quadrangle, Alaska: U.S. Geological Survey Open-File Report 80-811-H, 3 sheets.

King, H. D., O'Leary, R. M., Risoli, D. A., and Galland, D. W., 1983, Distribution and abundance of antimony and mercury in minus 80-mesh stream-sediment and antimony in nonmagnetic and moderately magnetic heavymineral concentrate samples, Medfra quadrangle, Alaska: U.S. Geological Survey OpenFile Report $80-811-\mathrm{L}, 2$ sheets.

King, H. D., Risoli, D. A., and Tripp, R. B., 1983, Distribution and abundance of molybdenum, tin, and tungsten in nonmagnetic and moderately magnetic heavy-mineral concentrate samples and tin in minus 80-mesh streamsediment and ash of aquatic bryophyte samples, Medfra quadrangle, Alaska: U.S. Geological Survey Open-File Report 80-811-J, 4 sheets.

King, H. D., Tripp, R. B., O'Leary, R. M., and Cooley, E. F., 1983, Distribution and abundance of copper, lead, and zinc in nonmagnetic and moderately magnetic heavymineral concentrate, minus 80-mesh streamsediment, and ash of aquatic byrophyte samples, Medfra quadrangle, Alaska: U.S. Geological Survey Open-File Report 80-811-I, 6 sheets.
May, S. R., Coney, P. J., and Beck, M. E., 1983, Paleomagnetism and suspect terranes of the North American Cordillera: U.S. Geological Survey Open-File Report 83-799, 7 p., 1 pl., scale 1:5,000,000.

Mayfield, C. F., Tailleur, I. L., and Ellersieck, Inyo, 1983, Stratigraphy, structure, and palinspastic synthesis of the western Brooks Range, northwestern Alaska: U.S. Geological Survey Open-File Report 83-779, 61 p., 5 pl.

Mayfield, C. F., Curtis, S. M., Ellersieck, Inyo, and Tailleur, I. L., 1983, Reconnaissance geologic map of the De Long Mountains A3, B3, and parts of A4, B4 quadrangles, Alaska: U.S. Geological Survey Open-File Report 83-183, 60 p., scale 1:63,360, 2 sheets.

Menzie, W. D., Foster, H. L., Tripp, R. B., and Yeend, W. E., 1983, Mineral resource assessment of the Circle quadrangle, Alaska: U.S. Geological Survey Open-File Report 83-170-B, 61 p., scale 1:250,000, 1 pl.

Odum, J. K., Gardner, C. A., Yehle, L. A., Schmoll, H. R., and Dearborn, L. L., 1983, Preliminary lithologic, geotechnical, and geophysical data from drill hole $\mathrm{CW}-81-2$, Chuitna West coal field, Cook Inlet region, Alaska: U.S. Geological Survey Open-File Report 83-78, 14 p., 2 sheets.

Patton, W. W., Jr., and Moll, E. J., 1983, Mineral resource assessment map of the Medfra quadrangle, Alaska: U.S. Geological Survey OpenFile Report 83-811-G, scale 1:250,000, 3 sheets.

Reed, B. L., Lanphere, M. A., and Meisch, A. T., 1983, Chemical analyses of 102 tonalite samples for the Jurassic magmatic arc, AlaskaAleutian Range batholith, Alaska: U.S. Geological Survey Open-File Report 83-94, 18 p.

Severson, R. C., and Gough, L. P., 1983, Chemical composition and variability of soils from the Capps coal field, Alaska: U.S. Geological Survey Open-File Report 83-190, 39 p.

Williams, J. R., 1983, Engineering-geologic maps of northern Alaska, Meade River quadrangle: U.S. Geological Survey Open-File Report 83294, scale $1: 250,000,1$ sheet.

Wilson, F. H., and Cox, D. P., 1983, Geochronology, geochemistry, and tectonic environment of porphyry mineralization in the central Alaska Peninsula: U.S. Geological Survey Open-File Report 83-783, 25 p.

Yeend, Warren, 1983, Engineering-geologic maps of northern Alaska, Lookout Ridge quadrangle: U.S. Geological Survey Open-File Report 83279 , scale $1: 250,000,2$ sheets.

miscellaneous Field Studies

Detterman, R. L., and others, 1983, Generalized geologic map of Ugashik, Bristol Bay, and part of Karluk quadrangles, Alaska: U.S. Geological Survey Miscellaneous Field Studies Map MF-1539A. 
Johnson, B. R., and Karl, S. M., 1982 (1983), Reconnaissance geologic map of the Western Chichagof and Yakobi Islands Wilderness Study Area, southeastern Alaska: U.S. Geological Survey Miscellaneous Field Studies Map MF$1467 \mathrm{~A}$, scale 1:125,000, 1 sheet.

Kimball, A. L., and Still, J. C., 1983, Mineral resource potential of the Western Chichagof and Yakobi Islands Wilderness Study Area, southeastern Alaska: U.S. Geological Survey Miscellaneous Field Studies Map MF-1476B, scale $1: 125,000$.

Special Reports

A series of reports that are the result of computer treatment by the U.S. Geological Survey of data generated by the National Uranium Resource Evaluation (NURE) program of the Department of Energy is available through Byron R. Berger, Chief, Branch of Exploration Geochemistry, U.S. Geological Survey, Box 25046, Federal Center, Denver, CO. 80225. The analyses and sampling were done for the NURE program under the auspices of the Los Alamos Scientific Laboratories. Repopts have been prepared for the following quadrangles: Wiseman, Tanacross, Chandalar, Philip Smith Mountains, and Table Mountain.

Reports by U.S. Geological Survey authors in

non-Survey publications

Anders, D. E., King, J. D., and Lubeck, S. C., 1983, Correlation of oils and source rocks from the Alaskan North Slope (abs.) in Magoon, L. B., and Claypool, G. E., eds., $1 \overline{98} 3$, Alaska North Slope oil-rock correlation study-A compilation of abstracts: Dallas, Texas, American Association of Petroleum Geologists Short Course, p. 13-14.

Antweiler, J. C., and Cathrall, J. B., 1983, The relationship of gold in placer deposits of the Brooks Range, Alaksa, to primary gold sources (abs.): Alaska Science Conference, 34th, Whitehorse, Yukon, Proceedings, p. 94.

Bird, K. J., and Molenaar, C. M., 1983, The framework geology of the North Slope of Alaska as related to oil/source-rock correlations (abs.), in Magoon, L. B., and Claypool, G. E., eds., 1983, Alaska North Slope oil-rock correlation study-A compilation of abstracts: Dallas, Texas, American Association of Petroleum Geologists Short Course, p. 5-9.

Blanchard, D. C., and Tailleur, I. L., 1983, Pebble shale (Early Cretaceous) depositional environments in National Petroleum Reserve in Alaska (NPRA) (abs.), in American Association of Petroleum Geologists Annual Convention, Dallas, Texas, 1983, Book of Abstracts, p. 36-37.

Brew, D. A., 1983, Evaluation of suspect terranes in the Coast Plutonic-Metamorphic Complex, southeastern Alaska and part of British Columbia (abs.): Geological Society of
America Abstracts with Programs, v. 15, no. 5, p. 324.

Brew, D. A., and Morrel, R. P., 1983, Intrusive rocks and plutonic belts of southeastern Alaska, U.S.A., in Roddick, J. A., ed, 1983, Circum-Pacific plutonic terranes: Geological Society of America Memoir 159, p. 171193.

Claypool, G. E., 1983, Oil/source-rock correlation for Alaska North Slope-Principles and techniques (abs), in Magoon, L. B., and Claypool, G. E., eds, Alaska North Slope oil-rock correlation study-A compilation of abstracts: Dallas, Texas, American Association of Petroleum Geologists Short Course, p. 13.

Dillon, John, Dutro, J. T., Jr., and Brosgé, W. P., 1983, Interim geologic map of the Wiseman quadrangle, central Brooks Range, Alaska (abs.): Alaska Geological Society Symposium, New developments in the Paleozoic geology of Alaska and the Yukon, Anchorage, Alaska, 1983, Program and Abstracts, p. 17.

Donovan, T. J., Hendricks, J. D., Roberts, A. A., and Eliason, P. T., 1983, Experimental lowaltitude aeromagnetic reconnaissance for petroleum in Arctic National Wildlife Refuge, Alaska, using horizontal gradientsA progess report (abs.) in American Association of Petroleum Geologists Annual Convention, Dallas, Texas, 1983, Book of Abstracts, p. 63-64.

Dutro, J. T., Jr., 1983, Dry dredging in the Brooks Range-New Paleozoic fossil finds and their geologic impact (abs.): Alaska Geological Society Symposium, New developments in the Paleozoic geology of Alaska and the Yukon, Anchorage, Alaska, 1983, Program and Abstracts, p. 4.

Gaydos, Leonard, and Witmer, R. E., 1983, Mapping of arctic land cover utilizing Landsat digital data, in Permafrost, Fourth International Conference, Proceedings, University of Alaska, July 17-22, 1983: Washington, D.C., National Academy Press, p. 109-114.

Griscom, Andrew, and Case, J. E., 1983, Magnetic expression of geologic terranes in southern Alaska (abs.): Geophysics, v. 48 , no. 4 , p. 444-445.

Hildreth, Wes, 1983, The compositionally zoned eruption of 1912 in the Valley of Ten Thousand Smokes, Katmai National Park, Alaska: Journal of Volcanology and Geothermal Research, v. 18 , no. $1 / 4$, p. 1-56.

Hudson, Travis, and Arth, J. G., 1983, Tin granites of Seward Peninsula, Alaska: Geological Society of America Bulletin, v. 94, no. 6, p. 768-790.

Karl, S. M., and Hunt, S. J., 1983, Stratigraphy and turbidite facies associations in the Bay of Pillars Formation, southeastern Alaska (abs.): Alaska Geological Society Sym- 
posium, New developments in the Paleozoic geology of Alaska and the Yukon, 1982, Program and Abstracts, p. 18.

Kvenvolden, K. A., Rapp, J. B., and Bourell, J. H., 1983, North Slope, Alaska, oil-rock correlation study-Comparison of molecular markers (abs.), in Magoon, L. B., and Claypool, G. E., eds., Alaska North Slope oil-rock correlation study-A compilation of abstracts: Dallas, Texas, American Association of Petroleum Geologists Short Course, p. 26.

Lanphere, M. A., and Tailleur, I. L., 1983, K-Ar ages of bentonites in the Seabee Formation, northern Alaska-A Late Cretaceous (Turonian) time-scale point: Cretaceous Research, v. 4, no. 4, p. 361-370.

Magoon, L. B., and Claypool, G. E., eds., 1983, Alaska North Slope oil-rock correlation study-A compilation of abstracts: Dallas, Texas, American Association of Petroleum Geologists Short Course (Introduction to volume written by editors).

1983, Organic carbon content, hydrocarbon content, and vitrinite reflectance data within NPRA (National Petroleum Reserve in Alaska) (abs.), in Magoon, L. B., and Claypool, G. E., eds., Alaska North Slope oil-rock correlation study-A compilation of abstracts: Dallas Texas, American Association of Petroleum Geologists Short Course, p. 9-12.

Molenaar, C. M., 1983, Umiat field, an oil accumulation in a thrust-faulted anticline, North Slope of Alaska, in Powers, R. B., ed., 1983, Geologic studies of the Cordilleran thrust belt: Denver, Colo., Rocky Mountain Association of Geologists, v. 2, p. 537-548.

1983, Depositional relationships of Cretaceous and lower Tertiary rocks, northeastern Alaska: American Association of Petroleum Geologists Bulletin, v. 67, no. 7, p. 1066-1080.

Moore, T. E., and Nilsen, T. H., 1983, The fluvial sedimentology of the Upper Devonian and Lower Mississippian (?) Kanayut Conglomerate, Brooks Range, Alaska (abs.): Alaska Geological Society Symposium, New developments in the Paleozoic geology of Alaska and the Yukon, Anchorage, Alaska, 1983, Program and Abstracts, p. 3-4.

Orr, D. G., Trautwein, C. M., and Greenlee, D. D., 1983, Digital data base application to porphyry copper mineralization in Alaska-A case study (abs.): Geophysics, v. 48 , no. 4 , p. 475.

Patton, W. W., Jr., Moll, E. J., Dutro, J. T., Jr., Silberman, M. L., and Chapman, R. M., 1983, Geology of the Medfra quadrangle, westcentral Alaska, and its regional setting (abs.): Alaska Geological Society Symposium, New developments in the Paleozoic geology of Alaska and the Yukon, Anchorage,
Alaska, 1983, Program and Abstracts, p. 2122.

Spencer, C. P., and Engdahl, E. R., 1983, A joint hypocenter location and velocity inversion technique applied to the central Aleutians: Geophysies Journal, v. 72, no. 2, p. 399-415.

Stephens, C. D., Fogelman, K. A., Lahr, J. C., and Page, R. A., 1983, Evidence for a NNEdipping Benioff zone south of the Wrangell volcanoes, southern Alaska (Abs. s22-03): EOS (American Geophysical Union Transactions), v. 64 , no. 18 , p. 263.

Till, A. B., Dumoulin, J. A., Aleinikoff, John, Harris, Anita, and Carroll, P. I., 1983, Paleozoic rocks of the Seward Peninsula, Alaska-New insights (abs.): Alaska Geological Society Symposium, New developments in the Paleozoic geology of Alaska, Anchorage, Alaska, 1983, Program and Abstracts, p. 25 and 27.

Walker, D. A., Acevedo, W., Everett, K. R., Gaydos, L., Brown, J., and Webber, P. J., 1982, Landsat assisted enviromental mapping in the Arctic National Wildlife Refuge, Alaska: Hanover, N. H., Cold Regions Research and Engineeering Laboratory, CRREL Report 82-27, 59 p., scale 1:250,000, 2 pls.

\section{BUREAU OF MINES}

Barker, J. C., 1983, Reconnaissance of tin and tungsten in heavy metal panned concentrates along the trans-Alaska pipeline corridor north of Livengood, interior Alaska: Bureau of Mines Open-File Report 59-83, 24 p., 2 sheets, scale $1: 250,000$.

Clautice, K. H., 1983, Geological sampling and magnetic surveys of a tungsten occurrence, Bonanza Creek area, Hodzana highlands, Alaska: Bureau of Mines Open-File Report 8083,80 p., 4 sheets of sample grids.

Dahlin, D. C., Brown, L. L., and Kinney, J. J., 1983, Mountain and lower Kanuti River areas, central Alaska, Part II-Beneficiation: Bureau of Mines Information Circular 8916, 15 p.

DOWL Engineers and PLANgraphics, 1983, Mining properties acquisition costs-Kantishna Hills and Dunkle mine study areas, Denali National Park, Alaska: Contract report, prepared under Bureau of Mines contract No. SD134043; report available for review in Juneau Field Office, 128 p.

Foley, J. Y., and MeDermott, M. M., 1983, Podiform chromite occurrences in the Caribou Mountain and lower Kanuti River areas, central Alaska, Part I-Reconnaissance investigations: Bureau of Mines Information Circular 8915, 27 p.

Huang, S. L., 1983, Research into the safety and efficiency of underground placer mining and frozen ground: Contract report, prepared 
under contract no. B4620191 with the Mineral Industry Research Laboratory, University of Alaska, Fairbanks, 95 p.

Jansons, Uldis, 1983, Zinc-lead occurrences in and near the National Petroleum Reserve in Alaska; Bureau of Mines Mineral Land Assessment 121-82, $55 \mathrm{p}$.

Jansons, Uldis, Hoekzema, R. B., Kurtak, J. M., and Fechner, S. A., 1983, Mineral occurrences in the Chugach National Forest, south-central Alaska: Bureau of Mines Mineral Land Assessment 109-83, $34 \mathrm{p}$.

Meyer, M. P., 1983, Mineral investigation of the Iditarod-George planning block, central Kuskokwim River area, Alaska: Prepared for the Bureau of Land Management, 253 p.; available for review at the Juneau field of fice.

Naidu, A. S., 1983, Reconnaissance survey of heavy minerals in RARE II area of Prince William Sound, south Alaska: Contract Report, prepared under contract No. 80221062 from the Institute of Marine Science, University of Alaska, Fairbanks, 36 p.; available for review at the Juneau Field Office.

Nelson, S. W., and Jansons, Uldis, 1983, Study areas within the Chugach National Forest, Alaska, p. 28-31, in v. 1 of Marsh, S. P., Kropschot, S. J., and Dickinson, R. G., eds., Wilderness Mineral Potential-Assessment of mineral-resource potential in U.S. Forest Service lands studied 1964-1984: U.S. Geological Survey Professional Paper 1300 (Prepared in cooperation with the U.S. Bureau of Mines).

Nelson, S. W., Barnes, D. F., Dumoulin, J. A., Goldfarb, R. J., Koski, R. A., Miller, M. L., Mull, C. G., Pickthorn, W. J. (USGS), Jansons, Uldis, Kurtak, J. M., and Fechner, S. A. (BOM): 1984, Mineral resource potential map of the Chugach National Forest, Alaska: U.S. Geological Survey Miscellaneous Field Studies Map MF-1645-A, in press.

Roberts, W. S., 1984, Economic potential for chromium, platinum, and palladium in the Mount Hurst ultramafics, west-central area, Alaska: U.S. Bureau of Mines Open-File Report 22-84, 44 p. and appendix.

Salisbury and Dietz, Inc., 1983, Mineral resource studies, Kantishna Hills and Dunkle Mine areas, Denali National Park and Preserve: Contract Report, prepared under contract No. S0134031, Preliminary draft, 278 p., appendices; available for review at the Juneau Field Office.

\section{BUREAU OF LAND MANAGEMENT}

A listing of available noncompetitive oil and gas lease lands in Alaska is published monthly and is available from the Public Information Office in the Bureau's Anchorage office.The following reports are available through the
Public Affairs Office in the Bureau's Anchorage office:

Bureau of Land Management, 1983, Final Environmental Impact Statement on oil and gas leasing in the National Petroleum Reserve in Alaska: February 1983.

1983, Record of Decision on oil and gas leasing and development in the National Petroleum Reserve in Alaska: May 1983.

1983, The National Petroleum Reserve in Alaska (NPR-A) leasing program: An evaluation of the program's effects on subsistence use of the Reserve: October 1983 (modification of the Record of Decision).

Callahan, J. E., 1983, Geology and quality of coal beds in the Cretaceous Corwin Formation in the northern foothills of western arctic Alaska (abs.), in Proceedings of a symposium on Western Alaska Geology and Resource Potential, Anchorage, Alaska, 1982: Journal of the Alaska Geological Society, v. 3, p. 119.

\section{U.S. FISH AND WILDLIFE SERVICE}

U.S. Fish and Wildlife Service (in cooperation with the U.S. Geological Survey and the U.S. Bureau of Land Management), 1983, Proposed oil and gas exploration within the coastal plain of the Arctic National Wildlife Refuge, Alaska, Final Environmental Impact Statement and preliminary final regulations; Type of action: Administrative: U.S. Department of the Interior, $1 \mathrm{v}$.

1983, Final regulations for Exploration on the coastal plain of the Arctic National Wildlife Refuge, Part 4 of the Federal Register for April 19, 1983.

1983, Final Enviromental Impact Statement and preliminary final regulations-Proposed oil and gas exploration within the coastal plain of the Arctic National Wildlife Refuge, Alaska: 442 p. (The proposed action is to establish, by regulation, initial guidelines to govern surface geological exploration or geophysical exploration, or both, for oil and gas in the coastal plain of the refuge in accordance with section 1002(d) of ANILCA, the National Environmental Protection Act (NEPA) of 1969, and the regulations of the Council on Environmental Quality to implement the procedural provisions of NEPA).

1983, Arctic National Wildlife Refuge coastal plain assessment-Update report (1982), baseline study of the fish, wildlife, and their habitats: Region 7, Anchorage, 379 p. (Prepared in response to section $1022 \mathrm{c}$ of ANILCA).

Wohl, K. D., 1984, Fish and Wildlife Service policies and alternative strategies for coastal mineral development in Alaska: Region 7, Topical Brief R-7-1. (Available on microform 
from the Fish and Wildlife Service or University of Alaska's Arctic Environmental Information and Data Center offices in Anchorage.)

\section{NATIONAL PARK SERVICE}

Statement for management: Katmai National Park and Preserve

Statement for management: Kenai Fjords National Park

Statement for management: Wrangell-Saint Elias National Park

U.S. Department of the Interior, 1983, Environmental overview and analysis of mining effects-Gates of the Arctic National Park and Preserve: Denver, National Park Service, $168 \mathrm{p}$, maps.

(See also the Service's 215-page Draft Environmental Impact Statement, Denali National Park and Preserve, Kantishna Hills/ Dunkle Mine, Alaska, released in 1982.)

\section{U.S. DEPARTMENT OF AGRICULTURE-- FOREST SERVICE}

Forest Service, 1983, Supplement to the Draft Environmental Impact Statement and Draft Chugach National Forest Land and Resource Management Plan and Nellie Juan-College Fiord Wilderness Study Report: Administrative Document 116, 51 p. and appendices.

1983, Final Environmental Impact Statement-U.S. Borax 1982-1983 Operating Plan, Amendments 2, 3, and 4 for the Quartz Hill molybdenum claims, Tongass National Forest: Alaska Region Report 172, 211 p. and appendix.

1983, Alaska Regional Guide and Final Environmental Impact Statement for the Alaska Regional Guide: Alaska Region Reports $126 \mathrm{a}, 142$ p. and appendices $A-K ; 126 \mathrm{~b}, 81$ p. and appendices $\mathrm{A}-\mathrm{I}$.

1983, Greens Creek Final Environmental Impact Statement-Admiralty Island National Monument, Alaska (Proposed Noranda Mining, Incorporated project): Alaska Regional Administrative Document 115, 336 p.

1983, Tracy Arm-Fords Terror Environmental Assessment and Wilderness management prescriptions: (published by the Alaska Region) 36 p.

1983, Draft Environmental Impact Statement-Admiralty Island National Monument proposed boundary change: Alaska Region Report 129,38 p. and appendices A-F.

\section{DEPARTMENT OF ENERGY}

Department of Energy, 1983, State Energy Data Report Supplement, 1980-1981: DOE/EIA0214(81)S, 86 p. (Available from National Technical Information Service as PC A05/MF A01).
Department of Energy, Energy Information Administration, 1983, U.S. crude oil, natural gas, and natural gas liquids reserves, 1982 Annual Report: DOE/EIA-0216(82), 99 p.

Listed below are the quadrangles for which magnetic contour maps have been released in 1983 and the corresponding report number. The reports were prepared by Bendix Field Engineering Corp., and information on their availability can be obtained from the corporation's Technical Library, P.O. Box 1569, Grand Junction, CO 81502-1569.

Quadrangle Rept. No. Quadrangle Rept. No.

Barrow GJM-507 Point Lay GJM-513

Wainwr ight GJM-508 Utukok River GJM-514

Meade River GJM-509 Lookout GJM-515

$\begin{array}{lll}\text { Teshekpuk GJM-510 I Ridge } & \text { Ikpikpuk R. GJM-516 }\end{array}$

Harrison GJM-511 Umi at GJM-517

Bay Sagava- GJM-518

Beechey Pt. GJM-512 nirktok

The following were written in the 1950 s and are available for public purchase in microfiche only on the indicated Press Release (PR) number and date.

Moxham, R. M., (1952), Radioactive minerals in the Yakataga beach placers: U.S. Geological Survey, prepared for the U.S. Atomic Energy Commission, January 1952, 28 P., 1 pl.; PR No. $83-66 ; 12 / 8 / 83$.

Mulligan, J. J., (1956), Preliminary investigations of radioactive placers on Vulcan Creek-Clear Creek, Radium Gulch, Seward Peninsula: Bureau of Mines, prepared for the U.S. Atomic Energy Commission, 1956, 30 p.; PR No.83-17; 3/17/83.

Thomas, B. 1., and Herdlick, J. A., (1955) Preliminary investigations of tin and radioactive minerals in gold placer deposits near Tofty, Yukon River region, Alaska: Bureau of Mines, prepared for the U.S. Atomic Energy Commission, 1955, 33 p.; PR No. 83$17 ; 3 / 17 / 83$.

Wedrow, Helmuth, White, M. G., and Moxham, R. M., (1951/, Interim report on an appraisal of the uranium possibilities of Alaska: U.S. Geological Survey, March 1951, 124 p. 8 pl.; PR No. 83-52; 8/18/83.

\section{OTHER FEDERAL AGENCIES}

General Accounting Office, 1983, Issues facing the future of Alaskan North Slope Natural Gas: Resources Community Economic Division, 160 p.

\section{NON-FEDERAL PUBLICATIONS}

Adams, D. D., 1983, Geologic map of the northern contact area of the Arrigetch Peaks pluton, 
Brooks Range, Alaska: Alaska Division of Geological and Geophysical Surveys Professional Report 83, 1 sheet, scale 1:18,000.

Alaska Division of Geological and Geophysical Surveys, 1983, State of Alaska aeromagnetic surveys: Information Circular 20, 7 p., 1 pl.

1983, List of Alaska Division of Geological and Geophysical Surveys reports by region and quadrangle: Information Circular 27, $46 \mathrm{p}$. (published in first half of 1983).

Albanese, M. D., 1983, Geochemical reconnaissance of the Livengood B-3, B-4, C-3, and C-4 quadrangles, Alaska-Summary of data on stream-sediment, pan-concentrate, and rock samples: Alaska Division of Geological and Geophysical Surveys Report of Investigations $83-1,55$ p., 4 pls. (scale 1:63,360).

1983, Bedrock geologic map of the Livengood B-4 quadrangle, Alaska: Alaska Division of Geological and Geophysical Surveys Report of Investigations 83-3, 1 pl. (scale 1:40,000).

1983, Bedrock geologic outcrop map of the Livengood B-3 quadrangle, Alaska: Alaska Division of Geological and Geophysical Surveys Report of Investigations 83-6, 1 pl. (scale $1: 40,000)$.

Bruns, T. R., 1983, Model for the origin of the Yakutat block, an accreting terrane in northern Gulf of Alaska: Geology, v. 11, no. 12 , p. $718-721$.

Bundtzen, T. K., and Laird, G. M., 1983, Geologic map of the Iditarod D-1 quadrangle, Alaska: Alaska Division of Geological and Geophysical Surveys Professional Report 78, 1 pl. (scale $1: 63,360)$.

1983, Geologic map of the McGrath D-6 quadrangle, Alaska: Alaska Division of Geological and Geophysical Surveys Professional Peport 79, 1 pl. (scale 1:63,360). 1983, Preliminary geology of the northeastern Iditarod $\mathrm{C}-3$ quadrangle, Alaska: Alaska Divison of Geological and Geophysical Surveys Report of Investigations 83-13, 6 p., 1 pl. (scale 1:63,360).

Burns, L. E., Little, T. A., Newberry, R. J., Decker, J. E., and Pessel, G. H., 1983, Preliminary geologic map of parts of the Anchorage C-2, C-3, D-2, and D-3 quadrangles, Alaska: Alaska Division of Geological and Geophysical Surveys Report of Investigations 83-10, 3 pls. (scale 1:25,000).

Combellick, R. A., and Long, W. E., 1983, Geologic hazards, southeastern Alaska-An overview: Alaska Division of Geological and Geophysical Surveys Report of Investigations 83-17, $17 \mathrm{p}$.

Dillon, J. T., Adams, D. D., and Adler, Penny, 1983, Geologic map of the Melozitna A-4 quadrangle, Alaska: Alaska Division of Geological and Geophysical Surveys Report of
Investigations $83-18,1$ pl. (scale $1: 63,360$ ).

Gilbert, W. G., and Bundtzen, T. K., 1983, Paleozoic stratigraphy of Farewell area, southwest Alaska Range, Alaska: Alaska Geological Society Symposium, New developments in Paleozoic geology of Alaska and the Yukon, Anchorage, Alaska, 1983, Program and Abstracts, p. 10-11.

Gilbert, W. G., and Solie, D. N., 1983, Preliminary bedrock geology of the McGrath A-3 quadrangle, Alaska: Alaska Division of Geological and Geophysical Surveys Report of Investigations 83-7, 1 pl. (scale 1:63,360).

Helwig, James, and Emmet, Peter, 1983, Structure of the early Tertiary Orca Group in Prince William Sound and some implications for the plate tectonic history of southern Alaska (abs. 24317): Geological Society of America Abstracts with Program, v. 15, no. 5, p. 274275.

Hickman, R. G., 1983, Transverse folds, complex folds, and broken formation related to foreland thrusting, central Brooks Range, Alaska (abs. 21000): Geological Society of America Abstracts with Program, v. 15, no. 5, p. 313.

March, G. D., Photointerpretive map of surficial geology of the Skagway A-1 quadrangle, Alaska: Alaska Division of Geological and Geophysical Surveys Report of Investigations 83-14, 1 pl. (scale 1:63,360).

Marrs, D. C., 1983, Geologic map of the Ambler District, southwestern Brooks Range, Alaska (abs.): Alaska Geological Society Symposium, New developments in Paleozoic geology of Alaska and the Yukon, Anchorage, Alaska, 1983, Program and Abstracts, p. 19-20.

Morris, J. D., and Hart, S. R., 1983, Isotopic and incompatible element constraints on the genesis of island arc volcanies from Cold Bay and Amak Island, Aleutians, and implications for mantle structure: Geochimica et Cosmochimica Acta, v. 47, p. 2015-2030.

Motyka, R. J., Moorman, M. A., and Poreda, Robert, 1983, Thermal fluid investigations of the Makushin geothermal area, Unalaska Island, Alaska: Alaska Division of Geological and Geophysical Surveys Report of Investigations 83-15, $52 \mathrm{p.,} 1 \mathrm{pl}$.

Robinson, M. S., 1983, Bedrock geologic map of the Livengood C-4 quadrangle, Alaska: Alaska Division of Geological and Geophysical Surveys Report of Investigations 83-4, 1 pl. (scale 1:40,000).

Robinson, M. S., Smith, T. E., Bundtzen, T. K., and Albanese, M. D., 1983, Geology and metallogeny of the Livengood area, eastcentral Alaska (abs.): Alaska Geological Society Symposium, New developments in the Paleozoic geology of Alaska and the 
Yukon, Anchorage, Alaska, 1983, Program and Abstracts, p. 24.

Robinson, M. S., and Stephens, D. L., 1983, Geologic map of the Seward Peninsula, Alaska: Alaska Division of Geological and Geophysical Surveys Report of Investigations 83-20, scale 1:500,000, 1 sheet.

Sherman, G. E., 1983, Geology and mineralization of the Silver Fox mine, Fairbanks Mining District, Alaska: Alaska Division of Geological and Geophysical Survyes Reports of Investigations $83-9,3$ pls. (scale $1: 4,800$ ).

Smith, T. E., 1983, Bedrock geologic map of the Livengood C-3 quadrangle, Alaska: Alaska Division of Geological and Geophysical Surveys Report of Investigations $83-5,1 \mathrm{pl}$. (scale 1:40,000).

Solie, D. N., 1983, The Middle Fork plutonic complex, McGrath A-3 quadrangle, southwest Alaska: Alaska Division of Geological and Geophysical Surveys Report of Investigations 83-16, $17 \mathrm{p}$.

Updike, R. G., and Ulery, C. A., 1983, Preliminary geologic map of the Anchorage B-6 NW (Eklutna Lake) quadrangle, Alaska: Alaska Division of Geological and Geophysical Surveys Report of Investigations 83-8, 2 pls. (scale $1: 10,000)$.

oil and gas

Adams, B. H., 1983, Stress-sensitive permeability in a high-permeability sandstone reservoir-the Kuparuk field: Proceedings, Annual California Regional Meeting, Ventura, California, March 23-25, Society of Petroleum Engineers, p. 479486.

Boyer, R. C., and Wu, C., 1983, The role of reservoir lithology in design of an acidization program-Kuparuk River Formation, North Slope Alaska: Proceedings, Annual California Regional Meeting, Ventura, Calif., March 2325, Society of Petroleum Engineers, p. 519529.

Carman, G. J., and Hardwick, Peter, 1983, Geology and regional setting of Kuparuk oil field, Alaska: American Association of Petroleum Geologists Bulletin, v. 67, no. 6, p. 1014-1031.

Cloft, H. L., 1983, Stratigraphy and sedimentology of Ledge sandstone in Arctic National Wildlife Refuge in northeastern Alaska (abs.): American Association of Petroleum Geologists Annual Convention, Dallas, Texas, 1983, Book of Abstracts, p. 51-52.

Collett, T. S., 1983, Detection and evaluation of natural gas hydrates from well logs, Prudhoe Bay Alaska, in Permafrost-Fourth International Conference-Proceedings, University of Alaska, Fairbanks, July 17-22, 1983: Washington, D.C., National Academy Press, p. 169-174.
Collett, T. S., and Ehlig-Economides, C. A., 1983, Detection and evaluation of the in-situ natural gas hydrates in the North Slope region, Alaska: Proceedings, Annual California Regional Meeting, Ventura, Calif., March 23-25, Society of Petroleum Engineers, p. 97-106.

Cox, Bowman, 1983, World exploration outlookThe arctic: American Association of Petroleum Geologists Explorer, v. 5, no. 4, p. 18-20.

Ehm, Arlen, 1983, Oil and gas basins map of Alaska: Alaska Division of Geological and Geophysical Surveys Special Report, 1 sheet, scale $1: 2,500,00$.

Franz, U. A., Daly, A. R., and Brown, S. W., 1983, Organic facies of some Mesozoic rocks on Alaskan North Slope (abs.): American Association of Petroleum Geologists Annual Convention, 1983, Book of Abstracts, p. 75-76.

Goodman, M. A., and Giussani, A. P., 1983, In-situ gas hydrates-Evaluation of past experience and methods for field detection and testing: Houston, Texas, Enertech Engineering and Research Co., 167 p. (Sponsored by Gas Research Inst. of Chicago)

Husky Oil Operations, Inc., n.d., 1979 worker operation South Barrow Well no. 6: 8 p.

1983, Geologic report******: Anchorage, Alaska, Report for the U.S. Geological Survey, Office of National Petroleum Reserve in Alaska (each of the following wells is covered in a separate volume: Lisburne test well no. 1 , South Simpson well no. 1, Tunalkik test well no. 1, West Dease test well no. 1, East Simpson test well no. 2, Seabee test well no. 1, Drew Point test well no. 1, East Teshekpuk well no. 1, Ikpikpuk test well no. 1, Inigok test well no 1., J. W. Dalton test well no. 1, South Harrison Bay no. 1, West Fish Creek no. 1). 1983, Dual induction-laterolog-Report to the U.S. Geological Survey: (each of the following wells is covered in a separate volume: East Simpson test well no. 2, composite lithology; North Kalipik test well no. 1, 1978; Peard test well no. 1, lithology; Seabee test well no. 1, 1979, composite lithology; South Meade test well no. 1, 197879, composite lithology).

1983, History of drilling operations: Anchorage, Alaska, Report to the U.S. Geological Survey, Office of National Petroleum Reserve in Alaska (available from National Oceanic and Atmospheric Administration, Boulder, Colo.; histories for the following wells are available: Atigaru Point no. 1, East Simpson test well no. 1, Lisburne test well no. 1, North Inigok test well no. 1, Seabee test well no. 1, South Harrison Bay no. 1, Tunalik test well no. 1, W. T. Foran no. 1, Drew Point test well no. 1, Ikpikpuk test well no. 1, J. W. Dalton test well no. 1, Koluktak test well no. 1, South Simpson no. 1, Tulageak test well no. 
1, Awuna test well no. 1, Kuyanak test well no. 1, Peard test well no. 1, South Barrow well no. 13, South Barrow well no. 18, South Barrow well no. 20, U.S. Navy South Barrow well no. 14, Walakpa test well no. 2, South Barrow well no. 15, South Barrow well no. 16).

Jones, B. C., 1983, Oil and gas developments in Alaska in 1982: American Association of Petroleum Geologists Bulletin, v. 67, no. 10, p. 1593-1599.

Jones, W. A., and Rodeik, R. K., 1983, A discussion of crude oil production potential in Alaska and California: American Association of Petroleum Geologists Annual Convention, Dallas, Texas, 1983, Book of Abstracts, p. 104.

Kleist, J. R., Bard, T. R., Engstrom, D. B., Morrow, H. B., and Reber, S. J., 1983, Central Arctic foothills, Alaska-A unique challenge in frontier exploration (abs.): American Association of Petroleum Geologists Bulletin, v. 67. no. 3, p. 495-496.

Leonard, Jim, 1983, Big waterflood to boost Prudhoe recovery Alaska (abs.): American Association of Petroleum Geologists Annual Convention, Dallas, Texas, 1983, Book of Abstracts, p. 51-52.

Mull, C. G., 1982, Tectonic evolution and structural style of the Brooks Range, Alaska-An illustrated summary, in Powers, R. B., ed., Geologic studies of the Cordilleran Thrust Belt, v. 1: Denver, Colo., Rocky Mountain Association of Geologists, p. 1-45.

Oil and Gas Journal, 1983, ARCO's KieschnickAlaska is our production base to 2000: v. 81 , no. 41 , p. 67.

1983, Big Alaskan structure might be drilled soon: v. 81 , no. 36 , p. 66-67 (Marsh Creek anticline).

1983, ARCO biggest bidder in sale of NPRA lease: v. 81 , no. 30 , p. 84 (details of bidding for lease).

1983, Alaska adds three lease sales to 5 year plan: v. 81 , no. 45 , p. 73-75.

1983-See numerous other articles in v. 81 and 82.

Smith, T. N., and Petering, G. W., 1983, Petroleum potential of Upper Mesozoic strata in Lower Cook Inlet Basin on the basis of outcrops on Katmai National Monument (abs.), in Proceedings of a symposium on Western Alaska geology and resource potential, Anchorage, Alaska, 1982: Journal of the Alaska Geological Society, v. 3, p. 63.

Tetra Tech (for U.S. Geological Survey), 1983, Environmental monitoring report, National Petroleum Reserve-Alaska oil and gas exploration program, Fiscal year 1981: Anchorage, Tetra Tech. 97 p., 4 appendices.

The Mapmakers, 1983, (A two-sheet map set showing the January 1984 oil and gas lease status on the North Slope and Beaufort Sea:
Also available:

* From National Geophysical Data Center (325 Broadway, Boulder, Colo.): "Final gravity and magnetic report" and "Depth-seismic horizon sections, 20 profiles, 1:250,000" for the National Petroleum Reserve in Alaska.

* From the Anchorage office of Petroleum Information: information about chemical analyses of materials from five industry wells in the North Slope and one in the Copper River Basin.

* From the Alaska Map Service, Inc., a map outlining areas included in State and Federal 5-year petroleum lease sale projections. Single copies cost $\$ 35$ and are available from the company at P. O. Box 102794, Anchorage, AK 99510.

* See also Petroleum Information's Resume 83, a statistical review of 1983 national activity available from P. O. Box 2612, Denver, CO 80201 , for $\$ 75$.

Geothermal energy

Geothermal Resources Council, 1983, Geothermal resources-Energy on tap: Geothermal Resources Council, Annual Meeting, Portland Oregon, 1983, Transactions, v. 7. (Contains seven papers about Unalaska Island, a paper about the Pilgrim Springs area, and a paper about the eastern Copper River basin.)

1983, State Scene-Alaska: Geothermal Resources Council Bulletin, v. 12, no. 10, p. 12 (Makushin project).

Motyka, R. J., 1983, High-temperature hydrothermal resources in the Aleutian Arc, in Proceedings of a symposium on Western Alaska geology and resource potential, Anchorage, Alaska, 1982: Journal of the Alaska Geological Society, v. 3, p. 87-99.

Coal and peat

Alaska Division of Geological and Geophysical Surveys, 1983, Coal resources of Alaska: Information Circular 17, 9 p.

Lamberson, M. N., 1983, Petrographic analysis of the Canyon Creek, Alaska, subbituminous coal (abs.): Geological Society of America Abstracts with Programs, v. 15, no. 6, p. 622 (no. 17471).

Rao, P. D., and Smith, J. E., 1983, Petrology of Cretaceous coals from northern Alaska-Final technical report, Sept. 1, 1981, to Feb. 28, 1983: Fairbanks, University of Alaska Mineral Industry Research Laboratory MIRL Report No. 64 (for the U.S Department of Energy), $141 \mathrm{p}$.

Selleck, B. W., and Panuska, Bruce, 1983, Sedimentological models for the coal-bearing group (Oligocene-Miocene) central Alaska Range (abs.): Geological Society of America Abstracts with Programs, v. 15, no. 5, p. 683 (no. 28360). 
Nonfuel, critical, and strategic minerals

Alaska Department of Natural Resources, 1983, DNR locatable minerals management study-A report to Governor Sheffield: 31 p. (Available from the Department's Office of the Commissioner, 555 Cordova St., Anchorage)

Alaska Division of Geological and Geophysical Surveys, 1983, Mining claim location mapsContinuing series of map sets by $1: 250,000$ quadrangles. The following are ready: Anchorage, Beaver, Big Delta, Chandalar, Charley River, Circle, De Long Mountains, Eagle, Fairbanks, Juneau, Livengood, Mount Hayes, Ophir, Philip Smith Mountains, Talkeetna, Talkeetna Mountains, and Wiseman.

Blum, J. D., 1983, Petrology, geochemistry, and isotope geochronology of the Gilmore Dome and Pedro Dome, Fairbanks mining district, Alaska: Alaska Division of Geological and Geophysical Surveys Report of Investigations 83-2, 59 p.

Bundtzen, T. K., 1983, Mineral-resource modeling, Kantishna-Dunkle mine study areas, Alaska: Alaska Division of Geological and Geophysical Surveys Reports of Investigations 83-12, 51 p.

Bundtzen, T. K., and Gilbert, W. G., 1983, Outline of geology and mineral resources of upper Kuskokwim region, Alaska, in Proceedings of a symposium on western Alaska geology and resource potential, Anchorage, Alaska, 1982: Journal of the Alaska Geological Society, v. 3, p. 101-117.

Bundtzen, T. K., and others, 1984, Review of Alaska's mineral resources: Alaska Division of Geological and Geophysical Surveys Special Report 33, 56 p.

California Mining Journal, 1983, More Alaska mineral reserves outlined: v. 53 , no. 2 , p. 42 . 1983, Alaska Apollo outlining ore reserves: v. 53 , no. 4 , p. 6 . 1983, Juneau gold mines eyed by Canadians backed by Saudi Arabians: v. 53, no. 4, p. 5 .

David, Deb, 1983, "Too Much Gold Hill" - There's more than gold in this Fairbanks mine: Alaska Construction and Oil, v. 24, no. 9, p. 18-20 (gravel resources).

Eakins, G. R., Bundtzen, T. K., Robinson, M. S., Clough, J. G., Green, C. B., Clautice, K. H., and Albanese, M. A., 1983, Alaska's mineral industry, 1982: Alaska Division of Geological and Geophysical Surveys Special Paper 31, 63 p.

Exploration and Mining Journal, 1983, U.S. mine/plant activity: v. 10 , no. 5, p. 6 .

Hitzman, M. W., Smith, T. E., and Profett, J. M., 1983, Ambler schist belt of northwest AlaskaTerrane for world class massive sulfide deposits (abs.), in Proceedings on a symposium on western Alaska geology and resource potential, Anchorage, Alaska, 1982: Journal of the Alaska Geological Society, v. 3, p. 55.

McCracken, D., 1983, Gold dredging in Canada and Alaska, Part I: California Mining Journal, v. 52 , no. 7 , p. 30, 32-35.

1983, Gold dredging in Canada and Alaska Part II: California Mining Journal, v. 52, no. 8, p. 8-11.

1983, Gold dredging in Canada and Alaska, Part III: California Mining Journal, v. 52, no. 9 , p. $58,60,62-64$.

Metz, P. A., 1983, Bedrock stratigraphic, structural, and surficial depositional controls of the gold placer deposits of the Fairbanks mining district, Alaska (abs.), in Alaska Science Conference, 34th, Whitehorse, Yukon, 1983, Proceedings, p. 93.

Mining Journal, 1983, Unga Island preliminary reserves-Industry in action: v. 301 , no. 7741 , p. 474.

Moore, J, R., 1983, Placer mineral exploration in high latitudes, paper 0182 in Oceanology International Exhibition and Conference, Brighton, England, 1982: London, England, Copy Center.

Pacific Petroleum Geologists Newsletter, 1983, Alaska minerals mangement: OctoberNovember 1983, p. 3 .

Skilling's Mining Review, 1983, U.S. Borax and Chemical Corp.'s Quartz Hill molybdenum project in southeast Alaska: v. 72 , no. 12, p. 4-7.

Western Miner, 1983, Developing the Quartz Hill deposit of U.S. Borax: v. 56, no. 10 , p. 33-34.

Note: The Proceedings of the Fourth Inter national Conference, Permafrost, published by the National Academy Press, contains numerous articles about engineering geology, hydrology, botany, and other aspects of geological research in Alaska. 

